*ak RMIS View/Frint Document Cover Sheet tow

This document was retrieved from the Documentation and Records Manaqement (DRM) ISEARCH System. It is intended for Information only and may not be the most recent or updated version. Contact a Document Service Center (see Hanford Info for locations) if you need additional retrieval information.

Accession \#: D196075853

Document \#: SD-WM-ATR-149

Title/Desc:

ACCEPTANCE TEST REPORT FOR THE 241AN107 CAUSTIC ADDITION MIXER PUMP DATALOGGER

Pages: 107 


\begin{tabular}{|l|l|}
\hline 2. To: (Receiving Organization) & $\begin{array}{l}\text { 3. From: Criginating Organization) } \\
\text { TWRS/ENG }\end{array}$ \\
\hline KHC/ETS \\
AN-107 Caustic Addition & 6. Cog. Engr.: \\
\hline
\end{tabular}

8. Originator Remarks:

Document routed for review and approval prior to release.

\section{Related EDT No.:}

None

7. Purchase Order No.: N/A

9. Equip./Component No.: $\mathrm{N} / \mathrm{A}$

10. System/Bldg./Facility: 241-AN-274

11. Receiver Remarks:
12. Major Assm. Dwg. No.: N/A

13. Permit/Permit Application No.: $N / A$

14. Required Response Date: ASAP

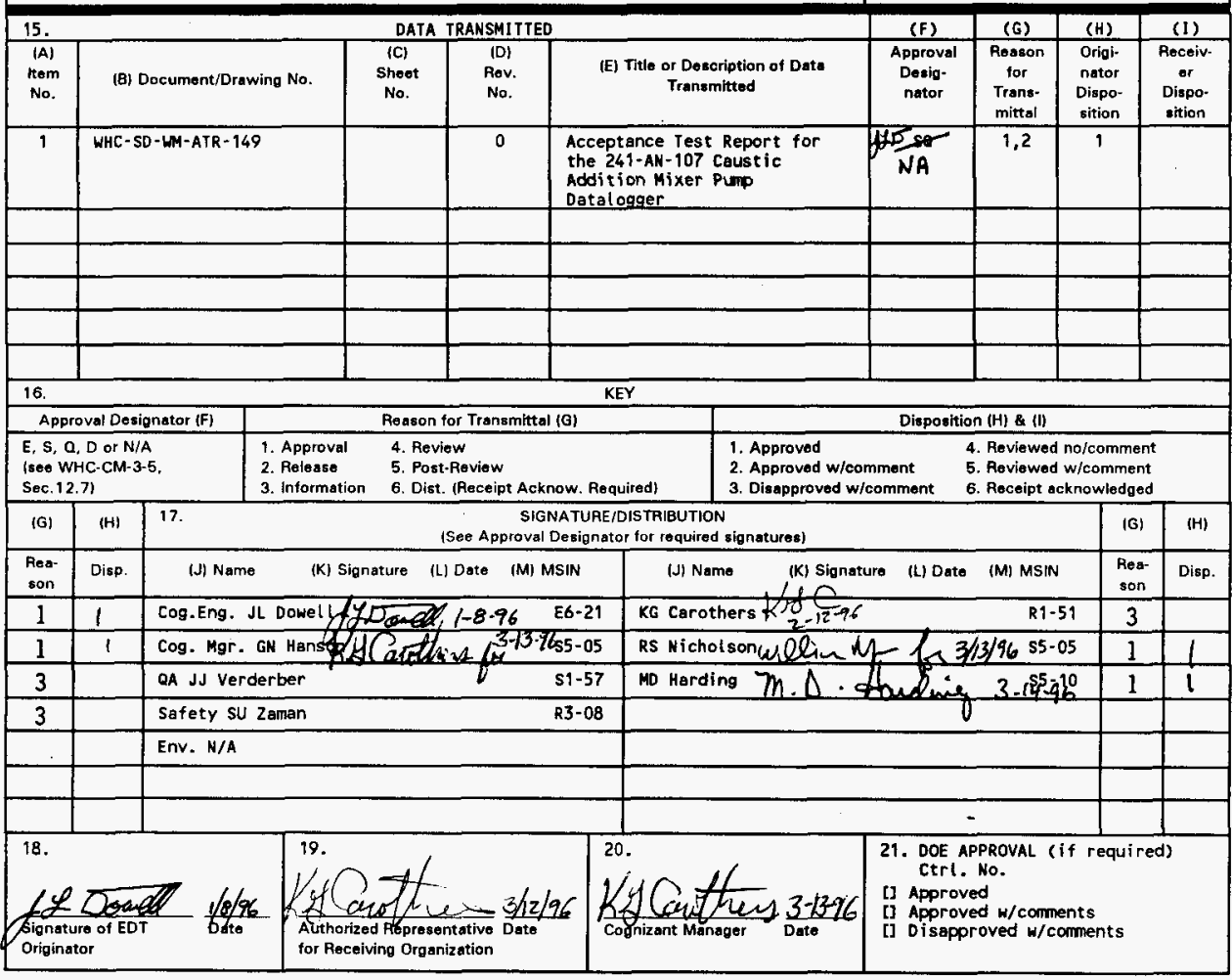

BD-7400-172-2 (04/94) GEF097 


\section{RELEASE AUTHORIZATION}

Document Number: WHC-SD-WM-ATR-149, REV 0

Document Title: Acceptance Test Report for the 241-AN-107 Caustic Addition Mixer Pump Datalogger

Release Date: $\quad 4 / 5 / 96$

This document was reviewed following the procedures described in WHC-CM-3-4 and is:

APPROVED FOR PUBLIC RELEASE

WHC Information Release Administration Specialist:
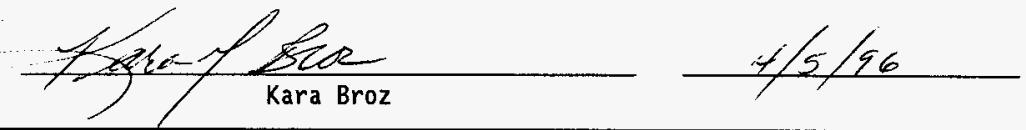

TRADEMARK DISCLAIMER. Reference herein to any specific commercial product, process, or service by trade name, trademark, manufacturer, or otherwise, does not necessarily constitute or imply its endorsement, recommendation, or favoring by the United States Government or any agency thereof or its contractors or subcontractors.

This report has been reproduced from the best available copy. Available in paper copy. Printed in the United States of America. To obtain copies of this report, contact:

Westinghouse Hanford Company - Document Control Services

P.0. Box 1970, Mailstop H6-08, Richland, WA 99352

Telephone: (509) 372-2420; Fax: (509) 376-4989 
2. Title

Acceptance Test Report for the 241-AN-107 Caustic Addition Mixer Pump Datalogger

5. Key Words

caustic addition, AN-107, mixer pump, datalogger, data acquisition, test report
3. Number

WHC-SD-WM-ATR-149

4. Rev No.

0
6. Author

Nane: J. L. Dowel1

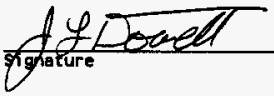

Organization/Charge Code

7. Abstract

The purpose of this report is to document that the Caustic Addition Mixer Pump Datalogger, functioned as intended as installed at 241-AN-107 tank farm.

Lotus $1-2-3$ is a trademark of the Lotus Development Corp.

8. RELEASE STAMP

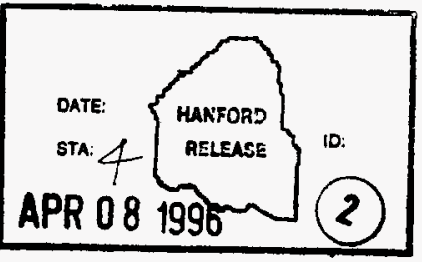




\title{
ACCEPTANCE TEST REPORT
}

\section{FOR THE}

\section{1-AN-107 CAUSTIC ADDITION MIXER PUMP DATALOGGER}

\author{
November 1995
}

\author{
J. L. Dowell
}

Westinghouse Hanford Company

P.O. Box 1970

Richland, Washington 99352 
WHC-SD-WM-ATR-149

Revision 0

\section{CONTENTS}

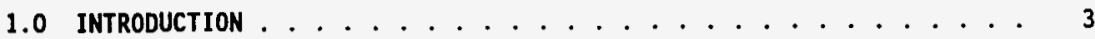

2.0 DESCRIPTION OF TEST . . . . . . . . . . . . . . . 3

2.1 THE WORKSTATION/COMPUTER CRITERIA . . . . . . . . . 3

2.2 DATALOGGER CRITERIA . . . . . . . . . . . 4

3.0 TEST METHOD AND TEST EQUIPMENT . . . . . . . . . . . . 4

4.0 TEST RESULTS . . . . . . . . . . . . . . . . 5

5.0 CONCLUSIONS AND RECOMMENDATIONS . . . . . . . . . . . . 6

6.0 DISPOSITION OF ITEM BEING TESTED . . . . . . . . . . . 6

Attachment A ........................... 
Revision 0

ACCEPTANCE TEST REPORT

FOR THE 24I-AN-107 CAUSTIC ADDITION MIXER PUMP DATALOGGER

\subsection{INTRODUCTION}

The Acceptance Test Procedure for the 241-AN-107 Caustic Addition Mixer Pump Datalogger, WHC-SD-WM-ATP-149, was started on September 25, 1995, and completed November 13, 1995. K. G. Carothers of Tank Waste Remediation Engineering requested the test procedure and ICF Kaiser Control Systems Engineering group wrote the test procedure and executed it at the 305 building in 300 area and at the 241-AN Tank Farm in 200 East area.

\subsection{DESCRIPTION OF TEST}

Testing was done in two phases: pre-installation testing at the 305 building in 300 Area, and post-installation testing at 241-AN Tank Farm. The purpose of the pre-installation testing portion (Section 1.7) was to formally close out engineering development activities by verifying and documenting the datalogger met the functional design criteria [1 isted in section 1.3 of the test procedure and reproduced below]. Once the datalogger successfully completed the pre-installation testing it was turned over for installation in the field.

The purpose of the post-installation testing (Section 1.8) was to verify the proper operation of each channel of the datalogger system. Testing was intended to verify that the datalogger met the functional, operational, and design requirements in its final in-service configuration. The computer workstation and datalogger were evaluated against the following criteria:

\subsection{THE WORKSTATION/COMPUTER CRITERIA}

2.1.1 Boots up to DOS prompt or the WAM menu.

2.1.2 Communicates with the datalogger via the serial interface using the Decipher program.

2.1.3 Displays data in engineering units with timestamp.

2.1.4 Transfers the data from the datalogger to the workstation memory.

2.1.5 Stores data in a Lotus $1-2-3^{T M}$ compatible format including the timestamp. 


\subsection{DATALOGGER CRITERIA}

2.2.1 Transfers the data to the workstation when commanded by the program.

2.2.2 If power is removed the datalogger will continue to record and will retain a 17 recorded data (until the battery is drained). When power returns the datalogger continues as before the power loss.

2.2.3 Runs the "schedule" to record the following seven parameters every 5 minutes when the Motor Torque exceeds 5\% (nominal):

\begin{tabular}{|c|c|c|c|}
\hline Parameter & $\begin{array}{c}\text { Datalogger } \\
\text { Channel }\end{array}$ & Low Range & High Range \\
\hline Pump motor power & 1 & 0 & $90 \mathrm{~kW}$ \\
\hline Pump motor rpm & 2 & 0 & 1800 \\
\hline Pump motor temperature & 3 & 50 & $250(\mathrm{deg} \mathrm{F})$ \\
\hline Pump column vibration & 4 & 0 & $1 \mathrm{in} / \mathrm{sec}$ \\
\hline Pump column strain & 5 & 0 & $1501 \mathrm{bs}$ \\
\hline Motor voltage & 6 & 0 & $460 \mathrm{Volt}$ \\
\hline Motor torque & 7 & 0 & $150 \%$ \\
\hline
\end{tabular}

Note: The signals for channels $1-5$ are a 0.4 to 2.0 volts (4-20 mA current

loop across a $100 \mathrm{ohm}, 0.1 \%$ resistor). The signal for channel 6 is a 0

to $6 \mathrm{~V} \mathrm{dc}$ voltage. The signal for channel 7 is a 0 to $10 \mathrm{~V}$ dc voltage.

\subsection{TEST METHOD AND TEST EQUIPNENT} steps:

The test method for the pre-installation portion followed these general

1. Assure the computer communicated with the datalogger.

2. Put a low-scale/near zero signal on Channel 1 .

3. Trigger Channel 7 by simulating an input of 0.33 volts.

4. Take at least 3 readings.

5. Change the signal to mid-scale; take at least 3 readings.

6. Change the signal to full-scale (or near full-scale); take at least 3 readings.

7. Change the signal to low-scale/near zero; take at least 3 readings.

8. Change Channel 7 to under 0.32 volts (to end recording).

9. Repeat steps 2 through 8 for Channels 2 through 6.

10. Assure Channel 7 responds.

11. Transfer readings from datalogger to computer disc.

12. Repeat steps 2 through 9 above, except after doing Channel 4 , turn off datalogger power for 1 minute, then turn power back on, then continue with Channels 5 through 7.

13. Transfer readings from datalogger to computer disc.

14. Evaluate the data. 
For the post-installation testing, the general test method was to:

1. Assure the computer communicated with the datalogger.

2. Put a mid-scale signal on Channel 1 .

3. Trigger Channel 7 by simulating an input of 0.33 volts.

4. Take 2 readings.

5. Change Channel 7 to under 0.32 volts.

6. Repeat steps 2 through 5 for Channels 2 through 6 .

7. Assure Channel 7 responds.

8. Transfer readings from datalogger to computer disc.

9. Evaluate the data.

Test equipment included 2 signal sources, and (if uncalibrated) a calibrated multimeter plus an assortment of hand tools.

\subsection{TEST RESULTS}

Pre-installation test results: Communication between the datalogger and computer workstation was without problems. The datalogger performed well but several minor test exceptions (TE \#1 thru 5) were generated. Test Exception (TE) \#1 noted a minor test measurement equipment failure (batteries died) that had no impact on test performance. The balance of the Test Exceptions dealt with minor "glitches" in the procedure itself or minor errors in performance of the procedure.

Post-installation test results: During the informal checkout communication problems between the datalogger and computer workstation were traced to a poor connection. Once the connectors were reseated the datalogger communicated with the computer workstation. Testing appeared to go well, but again several Test Exceptions (TE \#6-9) were generated. These again dealt with minor procedural corrections, a missing nameplate and an interuption for some troubleshooting. However, upon graphing the data channel by channel it was discovered that the static signal on Channel 5 was equal to the signal applied during the procedure. Thus, it was not possible to unambiguously state that Channel 5 responded to the applied signal. Thus TE \#10 was generated and Channel 5 was retested. The retest modified the procedure slightly and a mid-scale signal was applied for the first reading, but a slightly higher signal was applied for the second reading. Channel 5 responded exactly as expected and the post-installation test was ended.

The DeCipher program batch file successfully communicated with the datalogger and obtained the data. The datalogger files were successfully converted into a spreadsheet compatible file. A copy of the test control copy of the procedure is in Attachment $A$. The data sheets containing all data taken are included in Attachment $A$ as are the channel by channel graphs of the data recorded plus the Test Exeptions, Test Log, and Test Execution Sheet.

Test exceptions were generated for all steps that were not performed satisfactorily or were modified and all text exceptions were resolved satisfactorily. 
WHC-SD-WH-ATR-149

Revision 0

\subsection{CONCLUSIONS AND RECOMMENDATIONS}

The results of the Test Procedure shows the datalogger functions as required for the 241-AN-107 Caustic Addition program.

\subsection{DISPOSITION OF ITEM BEING TESTED}

The datalogger, computer workstation, DeCipher program, and "batch" file CA_PUMP.CMD were all accepted as tested and are ready for operational use. 
WHC-SD-WM-ATR-149

Revision 0

Attachment $A$

Master Copy

Acceptance Test Procedure for the

241-AN-107 Caustic Addition Mixer Pump Datalogger WHC-SD-WM-ATP-149 
WHC-SD-WM-ATR-149

\section{Revision 0}

\section{ACCEPTANCE TEST PROCEDURE}

FOR THE 241-AN-107

CAUSTIC ADDITION MIXER PUMP DATALOGGER

September 1995

J. L. Dowell

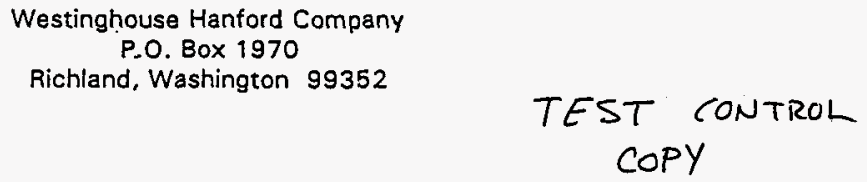


1.0 INSTRUCTION SECTION

1.1 PURPOSE/SCOPE

1.2 DESCRIPTION OF THE SYSTEM

1.2.1 The Datalogger

1.2.2 The Decipher software

1.3 CRITERIA

1.3.1 The Workstation/Computer Criteria . . . . . . 5

1.3.2 Datalogger Criteria ............. 5

1.4 REFERENCES . . . . . . . . . . . . . . . . 6

1.4.1 Drawings/ECN . . . . . . . . . . . 6

1.5 RESPONSIBILITIES ................. . . . 6

1.5.1 Project Engineer . . . . . . . . . . . . . 6

1.5 .2 Test Director ............... . 7

1.5 .3 Safety .................. . . 7

1.5 .4 Recorder. . . . . . . . . . . . . . 8

1.5 .5 Quality ............. . . 8

1.6 TEST CONDITIONS \& EQUIPMENT REQUIRED . . . . . . . . 9

1.6.1 Test Conditions . . . . . . . . . . . . . . . 9

1.6.2 Equipment Required . . . . . . . . . . . . g

1.7 ACCEPTANCE TEST - PRE-INSTALLATION . . . . . . . . 10

1.7.1 Preliminary Conditions . ............ 10

1.7 .2 Datalogger Setup .............. 11

1.7.3 Datalogger Test: Normal operation .......... 12

1.7 .4 Display Logged Data .............. 13

1.7.5 Datalogger Test: Loss of power operation . . . . . . 14

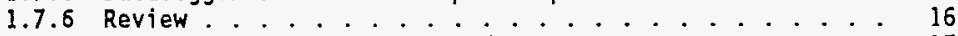

1.8 ACCEPTANCE TEST - POST INSTALLATION . . . . . . . . . . 17

1.8.1 Preliminary Conditions . . . . . . . . . . . . 17

1.8.2 Datalogger Setup . . . . . . . . . . . . 18

1.8.3 Datalogger: Record Data ............ 19

1.8 .4 Display Logged Datab . . . . . . . . . . . . 21

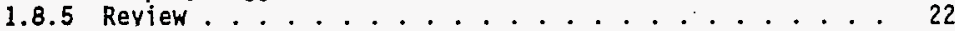

1.9 TEST DATA SHEETS .................. . . . 23

1.10 TEST LOG SHEET . . . . . . . . . . . . . 23

2.0 CHANGE CONTROL AND EXCEPTIONS TO ACCEPTANCE TEST SECTION . . . . . 24

2.1 ACCEPTANCE TEST PROCEDURE CHANGE CONTROL . . . . . . . 24

2.2 TEST EXECUTION ............................. 24

2.2.1 Without Exception ............. 24

2.2.2 With Exception/Resolved ............. 24

2.2.3 With Exception/Outstanding............ 24

3.0 RECORDING AND RESOLVING EXCEPTIONS . . . . . . . . . . . . . 25

3.1 GENERAL . . . . . . . . . . . . . . . . 25

3.2 RECORDING ...................... 25

3.3 RETEST/RESOLUTION . . . . . . . . . . . . . . . 25

3.4 APPROVAL AND ACCEPTANCE . . . . . . . . ...... 25

3.5 DISTRIBUTIOH ......................... 25 
APPENDIX A - TEST DATA SHEETS . . . . . . . . . . . . . A-1 APPEMDIX B - TEST EXCEPTION SHEET . . . . . . . . . . . . . B-1 APPENDIX C - TEST LOG SHEET .................. C C-1 APPENDIX D - TEST EXECUTION SHEET . . . . . . . . . . . . D-1 APPENDIX E - DeCipher/DeTerminal SCREENS ............ E-1 APPENDIX F - FIGURES ...................... F-1 
WHC-SD-WM-ATR-149

Revision 0

ACCEPTANCE TEST PROCEDURE FOR

THE 241-AN-107 CAUSTIC ADDITION MIXER PUMP DATALOGGER

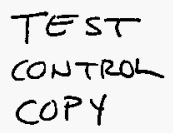

\subsection{INSTRUCTION SECTION}

\subsection{PURPOSE/SCOPE}

The purpose of this document is to demonstrate that the Data Logger monitoring the Caustic Addition Mixer pump functions per the design media and criteria. It is the intent of this test procedure to satisfy the requirements of an ATP to complete development (Section 1.7) and an OTP for the field installation (Section 1.8). Testing is expected to be done at the 305 Building (Section 1.7) and at 241-AN-274 (Section 1.8). Satisfactory completion of Section 1.7 is required before the datalogger and associated equipment are turned over for field installation. As of this writing, testing is expected to be performed in September 1995 and will take less than one week (excluding field installation) to complete.

The purpose of this procedure is to verify the data logger correctly records various parameters associated with the Caustic Addition Mixer pump. This test will also perform verification and validation of the programs and files associated with the datalogger. Testing described in this document will verify that the hardware and software function per the criteria (Section 1.3) prior to starting tank mixing tests.

\subsection{DESCRIPTION OF THE SYSTEM}

The Datalogger is a part of the AN-107 Caustic Addition Mixer Pump that periodically records 7 mixer pump parameters. The five 4-20 mA signals and two $D C$ voltage signals are generated by the mixer pump instruments and the Variable Frequency orive (VFD). In order to correlate the recorded data to other independent data acquisition activities all data will be time stamped.

The following items will be tested for functionality: the datalogger assembiy, DeCipher software (running on a standard workstation) using the datalogger "schedule", the interconnecting cables/wiring and other accessories.

\subsubsection{The Datalogger}

The datalogger has the terminals that connect to the various signals to be recorded. It also has a port to communicate to the workstation via the serial port using the DeCipher program.

\subsubsection{The DeCipher software}

Communicates to the datalogger via the serial interface using the DeCipher program and stores the data in a Lotus $1-2-3^{\text {TM }}$ file format. 


\subsection{CRITERIA}

This test procedure will be successful if the following criteria are met:

\subsubsection{The Workstation/Computer Criteria}

1.3.1.1 Boots up to DOS prompt or the WAM menu.

1.3.1.2 Communicates with the datalogger via the serial interface using the Decipher program.

1.3.1.3 Displays data in engineering units with timestamp.

1.3.1.4 Transfers the data from the datalogger to the workstation memory.

1.3.1.5 Stores data in a Lotus $1-2-3^{\text {rM }}$ compatible format including the timestamp.

\subsubsection{Datalogger Criteria}

1.3.2.1 Transfers the data to the workstation when commanded by the program.

1.3.2.2 If power is removed the datalogger will continue to record and will retain all recorded data (until the battery is drainedf. When power returns the datalogger continues as before the power loss.

1.3.2.3 Runs the "schedule" to record the following seven parameters every 5 minutes when the Motor Torque exceeds $5 \%$ (nominal):

\begin{tabular}{|c|c|c|c|}
\hline Parameter & $\begin{array}{c}\text { Datalogger } \\
\text { Channel }\end{array}$ & Low Range & High Range \\
\hline Pump motor power & 1 & 0 & $90 \mathrm{~kW} ?$ \\
\hline Pump motor rpm & 2 & 0 & 1800 \\
\hline Pump motor temperature & 3 & 50 & 250 (deg F) \\
\hline Pump column vibration & 4 & 0 & $1 \mathrm{in} / \mathrm{sec}$ \\
\hline Pump column strain & 5 & 0 & $150 \mathrm{Tbs}$ \\
\hline Motor voltage & 6 & 0 & $460 \mathrm{Volt}$ \\
\hline Motor torque & 7 & 0 & $150 \%$ \\
\hline
\end{tabular}

Note: The signals for channels $1-5$ are a 0.4 to 2.0 volts (4-20 mA current loop across a 100 ohm, $0.1 \%$ resistor). The signal for channel 6 is a 0 to $6 \mathrm{~V}$ dc voltage. The signal for channel 7 is a 0 to $10 \mathrm{~V}$ dc voltage. 
WHC-SD-WM-ATR-149

Revision $\mathrm{O}$

\subsection{REFERENCES}

\subsubsection{Drawings/ECH}

- ECN 621961, shows installation of data logger to monitor 5 parameters

- ECN 623762, shows connection of data logger to record motor voltage and motor torque.

- H-2-85573, Electrica1, Caustic Addition Project

Note: the above listing may not be complete.

\subsection{RESPONSIBILITIES}

Each organization participating in the execution of this Test procedure will designate personnel for the responsibilities and duties as defined herein for their respective roles. The names of these designees shall be provided to the Recorder for listing on the Recorder's copy of the Test Execution Sheet prior to the performance of any part of this Test procedure.

All individuals shall carry out their assigned work in a safe manner to protect themselves, others, and the equipment from undue hazards and to prevent damage to property and environment. Performance of test activities shall always include safety and health aspects as delineated in the operations manuals and as directed by the Project Engineer. Any hazard identified during the performance of the Test procedure shall be reported to the Test Director.

\subsubsection{Project Engineer}

\subsubsection{Designate a Test Director.}

1.5.1.2 Coordinate testing with facility management.

1.5.1.3 Act as liaison between the participants in testing.

1.5.1.4 Ensure informal testing and inspection is complete.

1.5.1.5 Schedule and conduct a meeting with test participants prior to the start of testing.

1.5.1.6 Notify the persons performing and witnessing the test prior to the start of testing.

1.5.1.7 Notify all concerned parties when a change is made in the testing schedule.

1.5.1.8 Approve field changes to this test procedure.

1.5.1.9 Sign/date Test Execution Sheet (Appendix 0) when This test procedure is approved and accepted.

1.5.1.10 Take necessary action to clear exceptions to this test procedure. 
1.5.1.11 Sign/date Test Exception Sheet (Appendix B) when an exception has been resolved.

1.5.1.12 Provide a distribution list for the approved and accepted test procedure.

1.5.1.13 Confirm that all equipment required for performing this test, as listed in Section 1.6.2, will be available for the test duration.

1.5.1.14 Provide equipment required for performing this test, which has not been designated as being provided by others.

\subsubsection{Test Director}

1.5.2.1 Witness the tests.

1.5.2.2 Coordinate all testing.

1.5.2.3 Confirm that shop testing (if any) and/or inspection (if any) of the test unit(s) or portion of the test unit(s) have been completed.

1.5.2.4 Stop any test which may cause damage to the test unit(s) until the test procedure has been revised.

1.5.2.5 Approve field changes to this test procedure.

1.5.2.6 Obtain revisions to this test procedure, as necessary, to comply with authorized field changes or to accommodate existing field conditions.

1.5.2.7 Evaluate recorded data, discrepancies, and exceptions.

1.5.2.8 Obtain from the Project Engineer, any information or changes necessary to clear or resolve exceptions.

1.5.2.9 Sign/date Test Data sheets and Test Execution sheet (Appendix A \& D) when execution of this test procedure has been completed.

1.5.2.10 Sign/date Test Exception Sheet (Appendix B) when acceptable retest has been performed.

1.5.2.11 Prepare and obtain required signatures on the Test Report prior to reproduction and distribution.

\subsubsection{Safety}

1.5.3.1 Review and approve this Test Procedure. 


\subsubsection{Recorder}

1.5.4.1 Witness testing and perform all recording using black ink.

1.5.4.2 Record names of all designated personnel on the Test Execution sheet (Appendix D) on the Recorder's copy of this test procedure prior to testing.

1.5.4.3 Observe tests, record test data (Appendix A) and maintain Test Log (Appendix C).

1.5.4.4 Sign/date the Test Execution Sheet, Test Data sheets and Test Exception sheet(s) (Appendices A, B \& D) as the Recorder.

1.5.4.5 Initial every test step on the Recorder's copy as it is completed, next to the step number and under the appropriate gauge identifier.

1.5.4.6 Record authorized field changes to this test procedure.

1.5.4.7 Record, on a Test Exception Sheet, exceptions and test steps that are either modified or are not performed. Additional Test Exception Sheets can be reproduced as needed (Appendix B).

1.5.4.8 Orally notify the Test Director at the time an objection is made.

1.5.4.9 After this test procedure is complete assign page numbers to Test Exception Sheets.

1.5.4.10 Submit the completed test procedure to the Test Director for approval signatures and distribution.

\subsubsection{Quality}

1.5.5.1 Witness the tests.

1.5.5.2 Evaluate recorded data, discrepancies, and exceptions.

1.5.5.3 Approve field changes to this test procedure.

1.5.5.4 Sign/date Test Execution Sheet (Appendix D) when execution of this test procedure is completed and again when it is approved and accepted.

1.5.5.5 Sign/date Test Exception Sheet (Appendix B) when an exception is made and again when it has been resolved.

1.5.5.6 Initial/mark Test Data sheets (Appendix A), assuring data is entered correctly. 


\subsection{TEST CONDITIONS \& EQUIPMENT REQUTRED}

\subsubsection{Test Conditions}

No unique or unusual chemical, fire, release of energy, or criticality safety hazards are involved with performing or supporting these tests. Normal laboratory and facility safety rules shall be followed during these tests. All electrical and mechanical apparatus shall be operated as designed.

The test items, equipment and facilities used in this test procedure are not expected to be affected permanently by this procedure. Test equipment that has been damaged shall be repaired or replaced.

The testing of the Datalogger will be performed in the 305 Building (Section 1.7, pre-installation) and 241-AN-274 building (Section 1.8, post installation).

\subsubsection{Equipment Required}

The Project Engineer shall assure all test equipment is available unless otherwise noted. The following list is provided as an aid and is not intended to be an exhaustive list.

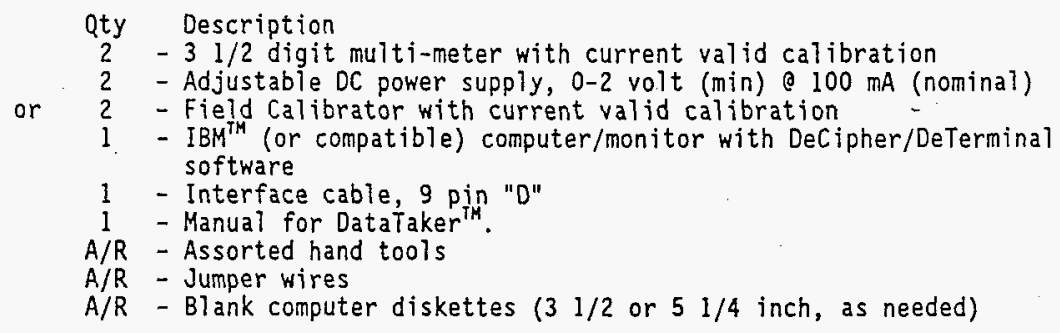




\subsection{ACCEPTANCE TEST - PRE-INSTALLATION}

\section{TEST CONTROL Copy}

\subsubsection{Preliminary Conditions}

The following shall be satisfactorily completed before performing Section 1.7.2.

1.7.1.1 The datalogger has been inspected for general workmanship and is connected per Figure 1, Appendix F.

1.7.1.2 Continuity and megger tests have been performed on portions of the electrical and instrument systems being tested, as required.

$\mathcal{P}$ 1.7.1.3 Al1 test instruments requiring calibration have a currently valid calibration stamp attached that indicates a calibration traceable to the National Institute of Standards and Testing.

1.7.1.4 Personnel responsible for directing and witnessing the performance of the tests described in this test procedure have read and understand their roles.

1.7.1.5 A11 other items have been tested to insure their proper function.

1.7.1.6 The test unit(s) and associated components have been checked and informally operated to ensure that they are in good general working order.

1.7.1.7 All components and equipment.are de-energized.

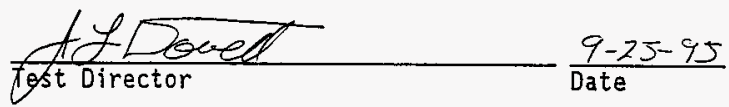




\subsubsection{Datalogger Setup}

The purpose of this section is to assure the workstation boots up properly and the datalogger communicates with the DeCipher program via the serial link.

1.7.2.1 Verify all the steps in Section 1.7.1 are complete.

$\mathcal{P}$ 1.7.2.2 Record the model number and serial number of the datalogger.

1.7.2:3 Turn on power to the computer, datalogger and any other associated equipment. Assure computer boots up normally.

1.7.2.4 Go to the subdirectory where "DeCipher" is located; type DCP <Enter> to start "DeCipher". Assure the appropriate messages and screen appears (see pages $7 \& 8$ of the DataTaker manual, "Getting Started with Datataker" and Appendix E).

1.7.2.5 In the Command menu, go to the Command Edit window. Open and load command file CA PUMP. This file will log all 7 analog data channels every 5 minutes when the motor torque exceeds $5 \%$, nominal.

P 1.7.2.6 Go to the Data menu. In the Source window, select "Logged then Stop". In the Select chans window assure all channels are selected.

1.7.2.7 Go to the File menu. In the Format window, select "Lotus". In the Channels window assure the "Time with Date" channel is selected and that all the other data channels are selected. In the Send To window select the following:

$\begin{array}{ll}\text { File } & \text { Yes } \\ \text { Name } & \text { [NORMDATA } \\ \text { Printer } & \text { No } \\ \text { Screen } & \text { Yes }\end{array}$

1.7.2.8 Go to the Run menu. In the Run what? window select the following:

$\begin{array}{ll}\text { File } & \text { Yes } \\ \text { Plot } & \text { No } \\ \text { Meter } & \text { No } \\ \text { Screen } & \text { File }\end{array}$

1.7.2.9 Return to the Command menu. From the Command Edit window, arrow up ( 1 ) to view the file CA PUMP. Alter the "report schedule" to $\log$ a 117 analog data channels with timestamp every 5 seconds (instead of every 5 minutes). Send the file to the datalogger by pressing Alt-A [Send All]. 
1.7.2.10 Assure the "report schedule" was correctly loaded by using the "STATUS2" command (Ref. page 4, headed "Schedules" of the DataTaker Manual). Record the report schedule reported using the "STATUS2" command.

\subsubsection{Datalogger Test: Normal operation}

The purpose of this section is to assure the datalogger records the data properly, transfers the data to the workstation, and stores the data in a Lotus $1-2-3^{\mathrm{m}}$ compatible file.

$1 P$ 1.7.3.1 Verify all the steps in Section 1.7 .2 are complete.

If 1.7.3.2 Assure the signal to the datalogger Channels 1 through 5 is 0.4 volts or less, and the signal to datalogger Channels 6 and 7 is 0.0 volts (nominal), unless otherwise directed.

1.7.3.3 Exit DeCipher to the Dos prompt. P 1.7.3.4 Set the Channel 7 signal to $0.33(-0.00,+0.02)$ volts. (This simulates a motor load of over $5 \%$ and starts the datalogger recording.) Record the Channel 7 voltage.

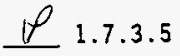
Set the Channel 1 signal to $0.4 \pm 0.05$ volts. Have it remain at this level long enough for 3 readings (min) to be taken by the datalogger. Record the Channel 1 voltage.

1201.3 .6

Set the Channel 1 signal to $1.2 \pm 0.05$ volts. Have it remain at this level long enough for 3 readings (min) to be taken by the datalogger. Record the Channel I voltage.

$\mathscr{L}$ 1.7.3.7 Set the Channel 1 signal to $2.0 \pm 0.05$ volts. Have it remain at this level long enough for 3 readings (min) to be taken by the datalogger. Record the Channel 1 voltage.

1.7.3.8 Set the Channel 1 signal to 0.4 volts or less. Have it remain at this level long enough for 3 readings (min) to be taken by the datalogger. Record the Channel 1 voltage.

$\Downarrow$ 1.7.3.9 Repeat Steps 1.7.3.5 to 1.7.3.8 for Channel 2.

1.7.3.10 Repeat Steps 1.7.3.5 to 1.7.3.8 for Channel 3 .

1.7.3.11 Repeat Steps 1.7.3.5 to 1.7.3.8 for Chanine! 4 .

$\mathcal{D}$ 1.7.3.12 Repeat Steps 1.7.3.5 to 1.7.3.8 for Channel 5 . 1.7.3.13 Set the Channel 6 signal to $0.1 \pm 0.05$ volts. Have it remain at
this level long enough for 3 readings (min) to be taken by the datalogger. Record the Channel 6 voltage. 
Set the Channel 6 signal to $3.0 \pm 0.05$ volts. Have it remain at this level long enough for 3 readings (min) to be taken by the datalogger. Record the Channel 6 voltage.

1.7.3.15 Set the Channel 6 signal to $5.8 \pm 0.05$ volts. Have it remain at this level long enough for 3 readings (min) to be taken by the datalogger. Record the Channel 6 voltage.

10 1.7.3.16 Set the Channel 6 signal to 0.1 volts or less. Have it remain at this level long enough for 3 readings (min) to be taken by the datalogger. Record the Channel 6 voltage.

$\$$ 1.7.3.17 Set the Channel 7 signal to $5.0 \pm 0.10$ volts. Have it remain at this level long enough for 3 readings ( $\mathrm{min}$ ) to be taken by the datalogger. Record the Channel 7 voltage.

I 1.7.3.18 set the Channel 7 signal to $9.9 \pm 0.10$ volts. Have it remain at this leve? long enough for 3 readings (min) to be taken by the datalogger. Record the Channel 7 voltage.

1.7.3.19 Set the Channel 7 signal to less than 0.30 volts. (This simulates a motor torque of less than $5 \%$, ending data recording). Record the Channel 7 voltage.

1.7.3.20 Go to the subdirectory where "DeCipher" is located, if needed; type DCP <Enter> to start the "DeCipher". Assure the appropriate messages and screen appears (see pages $7 \& 8$ of the DataTaker manual, "Getting Started with Datataker").

1.7.3.21 Transfer the data from the datalogger to the computer. Save the data as a Lotus $1-2-3^{n}$ compatible file. RECORD the drive, directory and file name.

\subsubsection{Display Logged Data}

The purpose of this section is to assure the data can be displayed in engineering units with timestamp.

P 1.7.4.1 Copy the data from the Data Logger memory to a file. Name the file NORMDATA.

1.7.4.2 Erase the internal memory of the Data Logger and erase the data in the From Datataker window of the Command menu.

TE21.7.4.3 Go to the File menu. In the Send To window select the following:

$\begin{array}{ll}\text { File } & \text { Yes } \\ \text { Name } & \text { [NORMDATA } \\ \text { Printer } & \text { No } \\ \text { Screen } & \text { Yes }\end{array}$


Tez 1.7.4.4 View the data; verify the data for channels 1 through 7 inclusive have a profile per Figure 2, Appendix $F$. loss

This section assures the datalogger will not lose data due to a power

Note: this section is similar to the Normal Operation section but power is removed from the datataker for a short time. Data is then examined to assure no loss occurred.

W 1.7.5.1 Assure the signal to the datalogger Channels 1 through 5 is 0.4 volts or less, and Channels 6 and 7 is 0.0 volts (nominal), unless otherwise directed.

1.7.5.2 Exit DeCipher to the DOS prompt.

1.7.5.3 Set the Channel 7 signal to $0.33(-0.00,+0.02)$ volts. (This simulates a motor load of over $5 \%$ and starts the datalogger recording.) Record the Channel 7 voltage.

$\forall$ 1.7.5.4 Set the Channel 1 signal to $0.4 \pm 0.05$ volts. Have it remain at this level long enough for 3 readings (min) to be taken by the datalogger. Record the Channel 1 voltage.

P 1.7.5.5 Set the Channel 1 signal to $1.2 \pm 0.05$ volts. Have it remain at this level long enough for 3 readings (min) to be taken by the datalogger. Record the Channel I voltage.

N 1.7.5.6 Set the Channel 1 signal to $2.0 \pm 0.05$ volts. Have it remain at this level long enough for 3 readings (min) to be taken by the datalogger. Record the Channel 1 voltage.

$T E \mathscr{V}$ 1.7.5.7 Set the Channel 1 signal to 0.4 volts or less. Have it remain at this level long enough for 3 readings (min) to be taken by the datalogger. Record the Channel l voltage.

1.7.5.8 Repeat Steps 1.7.5.4 to 1.7.5.7 for Channel 2.

P. 1.5.9 Repeat Steps 1.7.5.4 to 1.7.5.7 for Channel 3 .

$\mathcal{W}$ 1.7.5.10 Repeat Steps 1.7.5.4 to 1.7.5.7 for Channel 4 .

W 1.7.5.11 Remove power from the datalogger for about 1 minute; then restore the power.

L 1.7.5.12 Repeat Steps 1.7.5.4 to 1.7.5.7 for Channel 5 . 
P 1.7.5.13 Set the Channel 6 signal to $0.1 \pm 0.05$ volts. Have it remain at this level long enough for 3 readings (min) to be taken by the datalogger. Record the Channel 6 voltage.

1.7.5.14 Set the Channel 6 signal to $3.0 \pm 0.05$ volts. Have it remain at this level long enough for 3 readings (min) to be taken by the datalogger. Record the Channel 6 voltage.

P 1.7.5.15 Set the Channel 6 signal to $5.8 \pm 0.05$ volts. Have it remain at this level long enough for 3 readings (min) to be taken by the datalogger. Record the Channel 6 voltage.

1.7.5.16 Set the Channel 6 signal to 0.1 volts or less. Have it remain at this level long enough for 3 readings (min) to be taken by the datalogger. Record the Channel 6 voltage.

P 1.7.5.17 Set the Channel 7 signal to $5.0 \pm 0.10$ volts. Have it remain at this level long enough for 3 readings ( $m i n$ ) to be taken by the datalogger. Record the Channel 7 voltage.

P 1.7.5.18 Set the Channel 7 signal to $9.9 \pm 0.10$ volts. Have it remain at this level long enough for 3 readings (min) to be taken by the datalogger. Record the Channel 7 voltage.

1.7.5.19 Set the Channel 7 signal to less than 0.30 volts. (This simulates a motor load of less than $5 \%$, ending data recording).

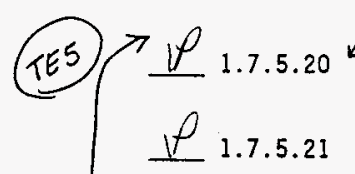
Cocth T-23.45 Copy the data from the Data logger memory to a file. Name the file PWR_OFF.

Erase the internal memory of the Data Logger and erase the data in the From Datataker window of the Command menu.

1.7.5.22 Go to the File menu. In the Send To window select the following:

$\begin{array}{ll}\text { File } & \text { Yes } \\ \text { Name } & \text { [PWR_OFF } \\ \text { Printer } & \text { No } \\ \text { Screen } & \text { Yes }\end{array}$

Go to the subdirectory where "DeCipher" is located, if needed; type DCP <Enter> to start the "DeCipher". Assure the appropriate messages and screen appears (see pages $7 \& 8$ of the DataTaker manual, "Getting Started with Datataker").

iew the data; verify the data for channels 1 through 7 inclusive have a profile per Figure 2, Appendix $F$.

P 1.7.5.25 Remove power from the datalogger and all other test equipment. 


\subsubsection{Review}

$\mathscr{P}$ 1.7.6.1 Verify that all steps in Section 1.7 have been satisfactorily completed.

1.7.6.2 Print out and include the following files as part of the test data: command file CA PUMP ; data files NORMDATA and PWR OFF and any graphs generated.

1.7.6.3 The cognizant engineer(s), by their signature below state that the Datalogger and associated equipment have satisfactorily completed development testing, are functional and ready for final installation at 241-AN-274.
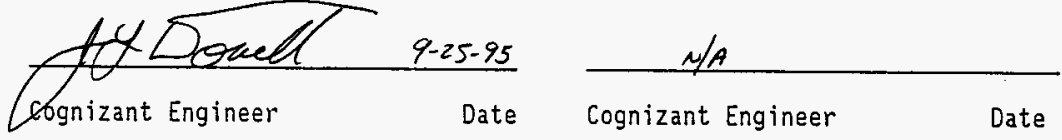


\subsection{ACCEPTANCE TEST - POST INSTALLATION}

\subsubsection{Preliminary Conditions}

The following shall be satisfactorily completed before performing Section 1.8.2.

KW 1.8.1.1 Verify all steps in Section 1.7 are satisfactorily completed.

Ku/1.8.1.2 The datalogger has been installed in 241-AN-274 per the design drawing(s) and applicable ECNs.

$\dot{K}_{w}$ 1.8.1.3 Continuity and megger tests have been performed on portions of the electrical and instrument systems being tested, as required.

Kw 1.8.1.4 All test instruments requiring caribration have a currentiy valid calibration stamp attached that indicates a calibration traceable to the National Institute of Standards and Testing.

KW 1.8.1.5 Personnel responsible for directing and witnessing the performance of the tests described in this test procedure have read and understand their roles.

$\mathrm{KW}$ 1.8.1.6 All other items have been tested to insure there proper function.

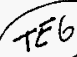

$6)$

1.8.1.7 All nameplates, equipment tags, etc. are installed/attached per the design drawing $(s)$.

$K_{\omega}$ 1.8.1.8 The test unit(s) and associated components have been checked and informally operated to ensure that they are in good general working order.

Nit 1.8.1.9 All components and equipment are de-energized. 8 will tor-95 $\mathrm{KW}$ 1.8.1.10 Assyre an Instrument Technician/Electrician and any other craft almely on support arg jeentified and available.

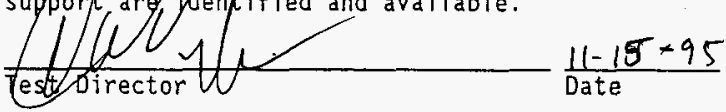




\subsubsection{Datalogger Setup}

TE-6 1.8.2.1 Verify all the steps in Section 1.8.1 are complete.

KW 1.8.2.2 Assure the computer is connected to the datalogger via the serial interface cable.

N/A 1.8.2.3 Turn on power to the computer, datalogger and any other associated equipment. Assure computer boots up normally.

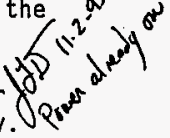

$K w$ 1.8.2.4 Go to the subdirectory where "DeCipher" is located; type DCP <Enter> to start the "DeCipher". Assure the appropriate messages and screen appears (see pages $7 \& 8$ of the DataTaker manual, "Getting Started with Datataker").

KW 1.8.2.5 In the Command menu, go to the Command Edit window. Open and load command file CA PUMP. This file will log all 7 analog data channels every 5 minutes after the motor torque exceeds $5 \%$ (nominal).

Kw 1.8.2.6 Go to the Data menu. In the Source window, select "Logged then Stop". In the Select Chans window assure all channels are selected.

Kw 1.8.2.7 Go to the File menu. In the Format window, select "Lotus". In the Channels window assure the "Time with Date" channel is selected and that all the other data channels are selected. In the Send To window select the following:

$\begin{array}{ll}\text { File } & \text { Yes } \\ \text { Name } & \text { [CAM_DAT } \\ \text { Printer No } & \text { No } \\ \text { Screen } & \text { Yes }\end{array}$

KW 1.8.2.8 Go to the Run menu. In the Run what? window select the following:

$\begin{array}{ll}\text { File } & \text { Yes } \\ \text { Plot } & \text { No } \\ \text { Meter } & \text { No } \\ \text { Screen } & \text { File }\end{array}$

KW 1.8.2.9 Return to the Command menu. From the Command Edit window, arrow up $(T)$ to view the file CA PUMP. Send the file to the datalogger by pressing Alt-A [Señd All].

Kw 1.8.2.10 Verify and record the "report schedule" was correctly loaded by using the "STATUS2" command (Ref. page 4, headed "Schedules" of The DataTaker Manual). 


\subsubsection{Datalogger: Record Data}

$1<W_{1.8 .3 .1}$ Verify all the steps in Section 1.8 .2 are complete.

$K W$ 1.8.3.2 Verify there is no power to the variable frequency drive for the caustic addition mixer pump.

Kw 1.8.3.3 Open the VFD enclosure.

$\mathrm{K}^{\mathrm{J}}$ 1.8.3.4 Lift wires $\mathrm{DL}-7-(+)$ and $\mathrm{DL}-7-(-)$ on TBI and connect to a signal source. Assure the signal source is at 0.1 volts $D C$ or less.

'W 1.8.3.5 Lift wires $\mathrm{DL}-6-(+)$ and $\mathrm{DL}-6-\langle-\rangle$ on $\mathrm{TBl}$ and connect to a signal source. Assure the signal source is at 0.1 volts $D C$ or less.

$\mathrm{Kw}$ 1.8.3.6 Set the signal source connected to wires $\mathrm{DL}-6-(+)$ and $\mathrm{DL}-6-(-)$ to $3.0 \pm 0.10$ volts. Record the value of this signal.

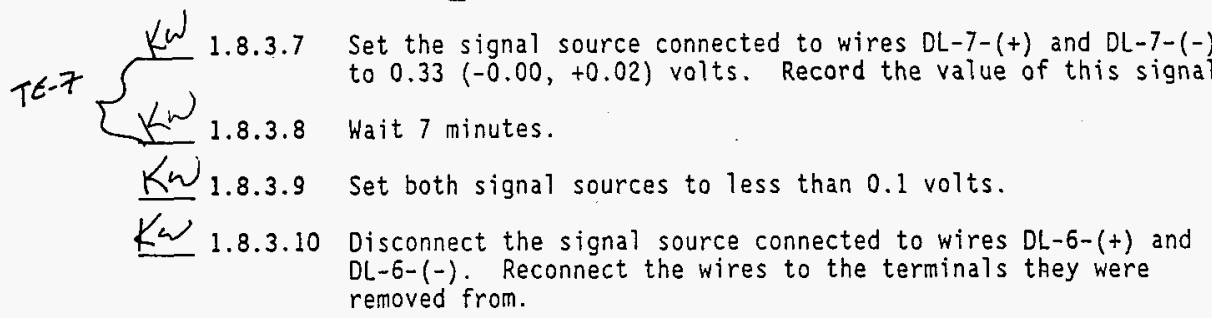

Note: The signal sources used, for the rest of this section, may be a 0.4-2.0 volt or a 4-20 mA source. The datalogger Channels 1 through 5 have a $100 \mathrm{ohm}(0.1 \%)$ resistor across the input terminals. Thus the personnel may freely use either type of signal source at the Test Directors discretion.

KN 1.8.3.11 Lift wires $D L-1-(+)$ and $D L-1-(-)$ on $T B-A B$ and connect to a signal source. Assure the signal source is at 0.4 volts or less.

$K \sim$ 1.8.3.12 Set the signal source connected to wires $D L-1-(+)$ and $D L-1-(-)$ to $1.2 \pm 0.05$ volts. Record the value of this signal.

$\mathrm{KW}$ 1.8.3.13 Set the signal source connected to wires $\mathrm{DL}-7-(+)$ and $\mathrm{DL}-7-(-)$ to $0.33(-0.00,+0.02)$ volts. Record the value of this signal.

KW 1.8.3.14 Wait 7 minutes.

KW 1.8.3.15 Set both signal sources to less than 0.1 volts. 
KW 1.8.3.16 Disconnect the signal source connected to wires $\mathrm{DL}-1-(+)$ and $\mathrm{OL}-1-(-)$. Reconnect the wires to the terminals they were removed from.

$K \omega$ 1.8.3.17 Lift wires $\mathrm{DL}-2-(+)$ and $\mathrm{DL}-2-(-)$ on $T B-A B$ and connect to a signal source. Assure the signal source is at 0.4 volts or less.

KW 1.8.3.18 Set the signal source connected to wires $\mathrm{DL}-2-(+)$ and $\mathrm{DL}-2-(-)$ to $1.2 \pm 0.05$ volts. Record the value of this signal.

$K$ 1.8.3.19 Set the signal source connected to wires $D L-7-(+)$ and $D L-7-(-)$ to $0.33(-0.00,+0.02)$ volts. Record the value of this signal.

Kw 1.8.3.20 Wait 7 minutes.

KW 1.8.3.21 Set both signal sources to less than 0.1 volts.

KW 1.8.3.22 Disconnect the signal source connected to wires $D L-2-(+)$ and $\mathrm{DL}-2-(-)$. Reconnect the wires to the terminals they were removed from.

KW 1.8.3.23 In the instrument cabinet lift wires $\mathrm{DL}-3-(+)$ and $\mathrm{DL}-3-(-)$ from TB-lA and connect to a signal source. Assure the signal source is at 0.4 volts or less.

KW 1.8.3.24 Set the signal source connected to wires $D L-3-(t)$-and $D L-3-(-)$ to $1.2 \pm 0.05$ volts. Record the value of this signal.

$\mathrm{Km}$ 1.8.3.25 Set the signal source connected to wires $\mathrm{DL}-7-(+)$ and $\mathrm{OL}-7-(-)$ to $0.33(-0.00,+0.02)$ volts. Record the value of this signal.

Kw 1.8.3.26 Wait 7 minutes.

KW 1.8.3.27 Set both signal sources to less than 0.1 volts.

$K w$ 1.8.3.28 Disconnect the signal source connected to wires $D L-3-(+)$ and $\mathrm{DL}-3-(-)$. Reconnect the wires to the terminals they were removed from.

$\mathrm{Kw}$ 1.8.3.29 In the instrument cabinet $1 \mathrm{ift}$ wires $\mathrm{DL}-4-(+)$ and $\mathrm{DL}-4-(-)$ from $T B-1 A$ and connect to a signal source. Assure the signal source is at 0.4 volts or $4 \mathrm{~mA}$.

KW 1.8.3.30 Set the signal source connected to wires $\mathrm{OL}-4-(+)$ and $\mathrm{OL}-4-(-)$ to $1.2 \pm 0.05$ volts. Record the value of this signal.

$\mathrm{KW}$ 1.8.3.31 Set the signal source connected to wires $\mathrm{OL}-7-(+)$ and $\mathrm{DL}-7-(-)$ to $0.33(-0.00,+0.02)$ volts. Record the value of this signal.

KW 1.8.3.32 Wait 7 minutes. 
Kw 1.8.3.33 Set both signal sources to less than 0.1 volts.

Kw 1.8.3.34 Disconnect the signal source connected to wires $D L-4-(+)$ and DL $-4-(-)$. Reconnect the wires to the terminals they were removed from.

$K N$ 1.8.3.35 In the instrument cabinet lift wires $\mathrm{DL}-5-(+)$ and $\mathrm{DL}-5-(-)$ from TB-IA and connect to a signal source. Assure the signal source is at 0.4 volts or less.

KW 1.8.3:36 Set the signal source connected to wires $D L-5-(+)$ and $0 L-5-(-)$ to $1.2 \pm 0.05$ volts. Record the value of this signal.

$\mathrm{KW}$ 1.8.3.37 Set the signal source connected to wires $\mathrm{DL}-7-(+)$ and $\mathrm{DL}-7-(-)$ to $0.33(-0.00,+0.02)$ volts. Record the value of this signal.

KN 1.8.3.38 Wait 7 minutes.

Kw 1.8.3.39 Set both signal sources to less than 0.1 volts.

$\mathrm{K}$ 1.8.3.40 Disconnect the signal source connected to wires $\mathrm{DL}-5-(+)$ and $\mathrm{DL}-5-(-)$. Reconnect the wires to the terminals they were removed from.

KW 1.8.3.41 Set the signal source connected to wires $D L-7-(+)$ and $D L-7-(-)$ to $5.0( \pm 0.10)$ volts. Record the value of this signal.

Kv 1.8.3.42 Wait 7 minutes.

Ka 1.8.3.43 Set the signal source to less than 0.1 volts.

$K \omega$ 1.8.3.44 Disconnect the signal source connected to wires $D L-7-(+)$ and $\mathrm{DL}-7-(-)$. Reconnect the wires to the terminals they were removed from.

KW 1.8.3.45 Close the door of the VFO.

1.8.3.46 Transfer the data from the datalogger to a computer drive. Save the data as a $1-2-3^{i M}$. compatible file. RECORD the drive, directory and file name.

\subsubsection{Display Logged Datab}

The purpose of this section is to assure the data can be displayed in engineering units with timestamp.

\footnotetext{
$\mathrm{KW}$ 1.8.4.1 Copy the data from the Data Logger memory to a file. Name the file CAM_DAT.
} 
$\left[{ }^{3}\right.$ 1.8.4.2 Erase the internal memory of the Data Logger and erase the data in the From Datataker window of the Command menu.

1.8.4.3 Go to the File menu. In the send To window select the following:

$\begin{array}{ll}\text { File } & \text { Yes } \\ \text { Name } & \text { CCAM_DAT } \\ \text { Printer } & \text { No } \\ \text { Screen } & \text { Yes }\end{array}$

View the data; verify the data for channels 1 through 7 inclusive have a profile per Figure 3, Appendix F.

Tt-9 1.8.4.5 Remove all test equipment connections and remove power from the

1.8 .5 Review

k. 1.8 .5 .

kat Kw11/15195

1.8.5.2 The cognizant engineer(s), by their signature below state that Kor 11-2.95 the Data logger and associated equipment are functional and ready for operational use at $241-A N-274$.
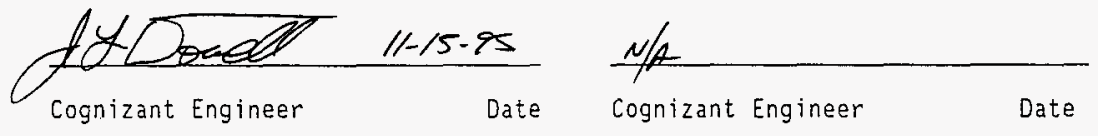
WHC-SD-WM-ATR-149

Revision 0
TEST

CONTRQ

COPY

\subsection{TEST DATA SHEETS}

The Test Data Sheets are used to document any procedure step requiring verification. All entries are made in black ink. A description of the data sheet format follows.

1. Date--Record the date the test is performed.

2. Title of Test Section--There are several sections of this one test being performed by this procedure, e.g. the Preliminary Conditions, Data logger Setup, etc.

3. Test Unit Number--Record the unit number of the test unit, if any.

4. Equipment Serial Number(s)--Record the serial numbers of any device used during the tests.

5. Test Performed By--Print the name of the person performing the test.

6. Procedure Step Number--This column contains the test steps requiring verification.

7. Item--This column contains the item being verified, (Pump, Air Conditioner, Heater, etc). or the parameter (voltage, pressure, etc.) being recorded.

8. Value--This column contains the quantitative or qualitative measure of the item being verified, i.e. a line voltage may have a value of $120 \mathrm{~V}$, whereas a pump may have a value of ON or OFF.

9. Range--This column indicates the anticipated value of the item being measured. If a value is recorded for later analysis, there may not be a tolerance associated with it.

10. Accept/Reject--Indicate whether the value obtained is acceptable in comparison with the Range. If a value is recorded for later analysis, the accept/reject decision may be determined later.

11. Comment--If the value is rejected, give a justification for denial.

12. $Q A--T h i s$ column indicates that $Q A$ concurred with the items recorded or verified.

Test Data Sheets are in Appendix A.

\subsection{TEST LOG SHEET}

Test Log Sheets are used to document test start and stop times and to document any other notes concerning the execution of the Acceptance Test Procedure. A Test $\log$ Sheet is included in Appendix $C$. 
WHC-SD-WM-ATR-149

Revision 0
TEST CONTROL

copy

\subsection{CHANGE CONTROL AND EXCEPTIONS TO ACCEPTANCE TEST SECTION}

\subsection{ACCEPTANCE TEST PROCEDURE CHANGE CONTROL}

Acceptance testing is to be conducted in accordance with the steps and requirements specified in this procedure. Any required field changes must be per Sections 1.5.2, 1.5.3, and 1.5.4. Field changes shall also be recorded as an exception.

\subsection{TEST EXECUTION}

The acceptance test procedures detailed in Section 1.7 and 1.8 shall be performed in sequential steps starting with Section 1.7.1. As required by Section 1.5.4, the Recorder will initial and date every test step in the space provided on the Recorder's copy of the ATP as each step is completed. Any step that requires verification must also be recorded on the Test Data Sheet.

\subsubsection{Without Exception}

2.2.1.1 Check applicable space on the Test Execution Sheet (Appendix D) to show that the ATP has been performed and no exceptions have been recorded.

2.2.1.2 Sign and date the Test Execution Sheet in the spaces provided.

2.2.1.3 Distribute requisite copies of ATP.

\subsubsection{With Exception/Resolved}

2.2.2.1 Check applicable space on the Test Execution Sheet to show that the ATP has been performed with exceptions recorded and resolved.

2.2.2.2 Sign and date the Test Execution Sheet in the spaces provided.

2.2.2.3 Distribute requisite copies of ATP.

\subsubsection{With Exception/Outstanding}

2.2.3.1 Check applicable space on the Test Execution Sheet to show that the ATP has been performed with exceptions recorded, part or all of which are presently outstanding, unresolved.

2.2.3.2 Sign and date the Test Execution Sheet in the spaces provided.

2.2.3.3 Distribute requisite copies of ATP. 
WHC-SD-WM-ATR-149

Revision 0

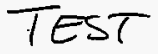

CONTROL Copy

\subsection{RECORDING AND RESOLVING EXCEPTIONS}

\subsection{GENERAL}

Exceptions to the ATP are sequentially numbered and recorded on individual Exception Sheets. This enables case-by-case resolution, recording, approval, and distribution of each exception.

\subsection{RECORDING}

3.2.1 Number each exception sequentially as it occurs and record it on a Test Exception Sheet.

3.2.2 Enter name and organization of objecting party for each exception.

3.2.3 Enter planned action to resolve each exception when such determination is made.

\subsection{RETEST/RESOLUTYON}

3.3.1 Record the action taken to resolve each exception on the Test Exception Sheet. Action taken may not be the same as planned action.

3.3.2 When action taken results in an acceptable retest, sign and date Acceptable Retest section of the Test Exception Sheet.-

3.3.3 When action taken does not involve an acceptable retest, strike out the Acceptable Retest section of the Test Exception Sheet. Resolve exception per Section 3.4 below.

\subsection{APPROVAL AND ACCEPTANCE}

3.4.1 The Project Engineer provides final approval and acceptance of exception by checking one of the following on the Test Exception Sheet:

- Retest Approved and Accepted: Applicable when Retest Execution and Acceptance section is completed.

- Exception Accepted-As-Is: Requires detailed explanation.

- Other: Requires detailed explanation.

3.4.2 The Project Engineer signs and dates the Test Exception Sheet and obtains other internal approval, if required.

\subsection{DISTRIBUTION} client.

Distribute requisite copies of completed the Test Exception Sheets to the 


\section{APPENDIX A - TEST DATA SHEETS}

Test Data Sheets.......................................A8

Graph 1: Channe1 1, Normal Operation...........................

Graph 2: Channel 2, Normal Operation.............................

Graph 3: Channe1 3, Normal Operation...............................

Graph 4: Channel 4, Normal Operation............................

Graph 5: Channel 5, Normal Operation............................

Graph 6: Channel 6, Normal operation..............................

Graph 7: Channel 7, Normal Operation...................................

Graph 8: Channe1 1, Loss of Power..................................

Graph 9: Channel 2, Loss of Power...............................

Graph 10: Channe1 3, Loss of Power..............................

Graph 11: Channel 4, Loss of Power............................

Graph 12: Channel 5, Loss of Power.............................

Graph 13: Channe1 6, Loss of Power.............................

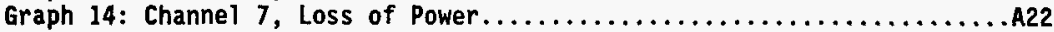

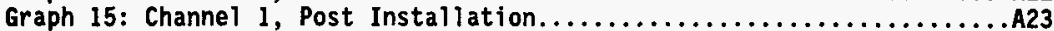

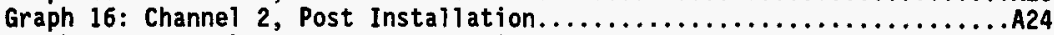

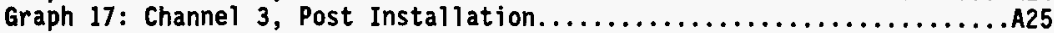

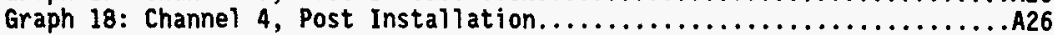

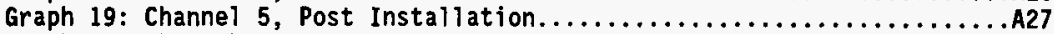

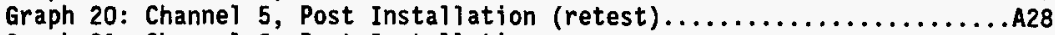

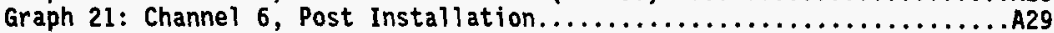

Graph 22: Channe] 7, Post Installation........................

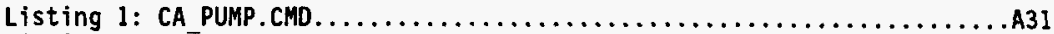

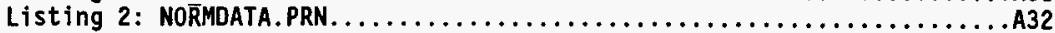

Listing 3: PWR OFF.PRN............................................

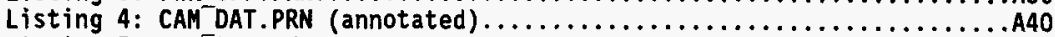

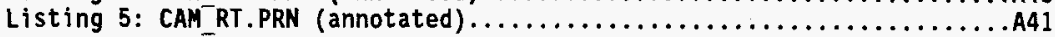


TEST DATA SHEET

\begin{tabular}{|c|c|c|c|c|c|c|}
\hline \multirow{3}{*}{\multicolumn{3}{|c|}{ 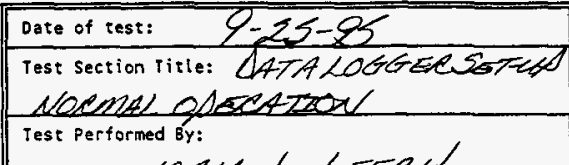 }} & \multirow{3}{*}{\multicolumn{4}{|c|}{ 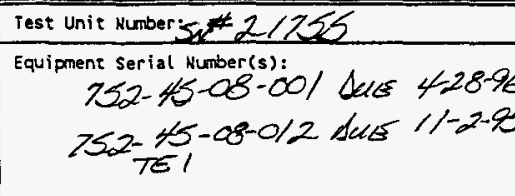 }} \\
\hline & & & & & & \\
\hline & & & & & & \\
\hline $\begin{array}{l}\text { Procedure Step } \\
\text { Number }\end{array}$ & Item & Range & Value & $(A / R)$ & Corment & AA \\
\hline 1.7 .2 .1 & $\begin{array}{l}\text { Section } \\
1.7 .1\end{array}$ & $\begin{array}{l}\text { Completed } \\
\text { (yes) }\end{array}$ & $y / E$ & $A$ & & $p$ \\
\hline \multirow[t]{2}{*}{1.7 .2 .2} & Model no. & Record Value & 605 & $A$ & & $P$ \\
\hline & Serial no. & Record Value & 21725 & $A$ & & $p$ \\
\hline 1.7 .2 .10 & $\begin{array}{l}\text { Report } \\
\text { Schedule }\end{array}$ & Record Value & $\begin{array}{l}2 X, A C T 2 V B \\
4, \text {,ALTEOS }\end{array}$ & A & & $p$ \\
\hline 1.7 .3 .1 & $\begin{array}{l}\text { Section } \\
1.7 .2\end{array}$ & $\begin{array}{l}\text { Completed } \\
\text { (yes) }\end{array}$ & $y / E S$ & $A$ & & $p$ \\
\hline 1.7 .3 .4 & $\begin{array}{l}\text { Channel } 7 \\
\text { voltage }\end{array}$ & $\begin{array}{l}0.33(-0.00 \\
+0.02) \text { volts }\end{array}$ & .332 & A & & $p$ \\
\hline 1.7 .3 .5 & $\begin{array}{l}\text { Channel } 1 \\
\text { voltage }\end{array}$ & $\begin{array}{l}0.4 \pm 0.05 \\
\text { volts }\end{array}$ & 0.400 & A & - & $P$ \\
\hline 1.7 .3 .6 & $\begin{array}{l}\text { Channel } 1 \\
\text { voltage }\end{array}$ & $\begin{array}{l}1.2 \pm 0.05 \\
\text { volts }\end{array}$ & 1.200 & A & & $P$ \\
\hline 1.7 .3 .7 & $\begin{array}{l}\text { Channel } 1 \\
\text { volt tage }\end{array}$ & $\begin{array}{l}2.0 \pm 0.05 \\
\text { volts }\end{array}$ & 2.00 & A & & $\rho$ \\
\hline 1.7 .3 .8 & $\begin{array}{l}\text { Channel } 1 \\
\text { voltage }\end{array}$ & $\begin{array}{l}0.4 \text { volts or } \\
\text { less }\end{array}$ & 0.40 & A & & $p$ \\
\hline \multirow[t]{4}{*}{1.7 .3 .9} & $\begin{array}{l}\text { Channel } 2 \\
\text { voltage }\end{array}$ & $\begin{array}{l}0.4 \pm 0.05 \\
\text { volts }\end{array}$ & 0.40 & A & & $p$ \\
\hline & $\begin{array}{l}\text { Channel } 2 \\
\text { voitage }\end{array}$ & $\begin{array}{l}1.2 \pm 0.05 \\
\text { voits }\end{array}$ & 1.20 & $A$ & & $P$ \\
\hline & $\begin{array}{l}\text { Channel } 2 \\
\text { voltage }\end{array}$ & $\begin{array}{l}2.0 \pm 0.05 \\
\text { volts }\end{array}$ & 2.00 & $A$ & 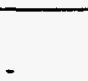 & $P$ \\
\hline & $\begin{array}{l}\text { Channel } 2 \\
\text { voltage }\end{array}$ & $\begin{array}{l}0.4 \text { volts or } \\
\text { less }\end{array}$ & 0.00 & $A$ & & $p$ \\
\hline
\end{tabular}


TEST DATA SHEET

\begin{tabular}{|c|c|c|c|c|c|c|}
\hline Dote of test: & \multicolumn{2}{|c|}{$9-25-95$} & \multicolumn{4}{|c|}{ Test Unit Number: $\mathrm{se} \# 2 / 735$} \\
\hline \multicolumn{3}{|c|}{$\begin{array}{l}\text { Test section Title: } \\
\text { NOCMAL ODECATZON }\end{array}$} & \multicolumn{4}{|c|}{$\begin{array}{l}\text { Equipnent Serial Number(s): } \\
752-45-08-00 / \text { dCIE } 4-28 \text {-9t }\end{array}$} \\
\hline \multicolumn{3}{|c|}{$\begin{array}{l}\text { Test Performed By: } \\
\text { NOCM } \cup \text { LEECH }\end{array}$} & \multicolumn{4}{|c|}{$12 \alpha-\infty+\infty+20$} \\
\hline $\begin{array}{l}\text { Procedure Step } \\
\text { Number }\end{array}$ & item & Range & Value & $(A / R)$ & comment & BA \\
\hline \multirow[t]{4}{*}{1.7 .3 .10} & $\begin{array}{l}\text { Channel } 3 \\
\text { voltage }\end{array}$ & $\begin{array}{l}0.4 \pm 0.05 \\
\text { volts }\end{array}$ & 0.40 & $A$ & & $p$ \\
\hline & $\begin{array}{l}\text { Channel } 3 \\
\text { voltage }\end{array}$ & $\begin{array}{l}1.2 \pm 0.05 \\
\text { volts }\end{array}$ & 1.20 & $A$ & & P \\
\hline & $\begin{array}{l}\text { Channel } 3 \\
\text { voltage }\end{array}$ & $\begin{array}{l}2.0 \pm 0.05 \\
\text { volts }\end{array}$ & 2.00 & $A$ & & $p$ \\
\hline & $\begin{array}{l}\text { Channel } 3 \\
\text { voltage }\end{array}$ & $\begin{array}{l}0.4 \text { volts or } \\
\text { less }\end{array}$ & 0.00 & $A$ & & $\varphi$ \\
\hline \multirow[t]{4}{*}{ 1.7.3.11 } & $\begin{array}{l}\text { Channel } 4 \\
\text { voltage }\end{array}$ & $\begin{array}{l}0.4 \pm 0.05 \\
\text { volts }\end{array}$ & 0.40 & $A$ & & $p$ \\
\hline & $\begin{array}{l}\text { Channel } 4 \\
\text { voltage }\end{array}$ & $\begin{array}{l}1.2 \pm 0.05 \\
\text { volts }\end{array}$ & 1.20 & $A$ & - & $\varphi$ \\
\hline & $\begin{array}{l}\text { Channel } 4 \\
\text { voltage }\end{array}$ & $\begin{array}{l}2.0 \pm 0.05 \\
\text { volts }\end{array}$ & 2.00 & $A$ & & $p$ \\
\hline & $\begin{array}{l}\text { Channel } 4 \\
\text { voltage }\end{array}$ & $\begin{array}{l}0.4 \text { volts or } \\
\text { less }\end{array}$ & 0.00 & $A$ & & $\rho$ \\
\hline \multirow[t]{4}{*}{1.7 .3 .12} & $\begin{array}{l}\text { Channel } 5 \\
\text { voltage }\end{array}$ & $\begin{array}{l}0.4 \pm 0.05 \\
\text { volts }\end{array}$ & 0.40 & $A$ & & $p$ \\
\hline & $\begin{array}{l}\text { Channel } 5 \\
\text { voltage }\end{array}$ & $\begin{array}{l}1.2 \pm 0.05 \\
\text { volts }\end{array}$ & 1.20 & $A$ & & $p$ \\
\hline & $\begin{array}{l}\text { Channel } 5 \\
\text { voltage }\end{array}$ & $\begin{array}{l}2.0 \pm 0.05 \\
\text { volts }\end{array}$ & 2.00 & $A$ & & $p$ \\
\hline & $\begin{array}{l}\text { Channel } 5 \\
\text { voltage }\end{array}$ & $\begin{array}{l}0.4 \text { volts or } \\
\text { less }\end{array}$ & 000 & $A$ & & $P$ \\
\hline
\end{tabular}


TEST DATA SHEET

\begin{tabular}{|c|c|c|c|c|c|c|}
\hline Date of test: & \multicolumn{2}{|l|}{$9-25-25$} & \multicolumn{4}{|c|}{ Test Unit Number: $5 \mu \# 2 / 755$} \\
\hline \multicolumn{3}{|c|}{$\begin{array}{l}\text { Test section ritle: } \\
\text { MOCMAL OAECATZON-L. }\end{array}$} & \multicolumn{4}{|c|}{$\begin{array}{l}\text { Equipnent serial Number(s): } \\
752-45-08-00 / \text { SuE } 428-96\end{array}$} \\
\hline \multicolumn{3}{|c|}{ Test Performed By: } & \\
\hline $\begin{array}{l}\text { Procedure step } \\
\text { Number }\end{array}$ & item & Range & value & $(A / R)$ & compent & QA \\
\hline 1.7 .3 .13 & $\begin{array}{l}\text { Channel } 6 \\
\text { voltage }\end{array}$ & $\begin{array}{l}0.1 \pm 0.05 \\
\text { volts }\end{array}$ & 0.100 & $A$ & & $p$ \\
\hline 1.7 .3 .14 & $\begin{array}{l}\text { Channel } 6 \\
\text { voltage }\end{array}$ & $\begin{array}{l}3.0 \pm 0.05 \\
\text { volts }\end{array}$ & 3.00 & A & & $p$ \\
\hline 1.7 .3 .15 & $\begin{array}{l}\text { Channel } 6 \\
\text { voltage }\end{array}$ & $\begin{array}{l}5.8 \pm 0.05 \\
\text { volts }\end{array}$ & 5.80 & $A$ & & $P$ \\
\hline 1.7 .3 .16 & $\begin{array}{l}\text { Channel } 6 \\
\text { voltage }\end{array}$ & $\begin{array}{l}0.1 \text { volts or } \\
\text { less }\end{array}$ & 0.00 & $A$ & & P \\
\hline 1.7 .3 .17 & $\begin{array}{l}\text { Channel } 7 \\
\text { voltage }\end{array}$ & $\begin{array}{l}5.0 \pm 0.10 \\
\text { volts }\end{array}$ & 5.00 & $A$ & & $p$ \\
\hline 1.7 .3 .18 & $\begin{array}{l}\text { Channel } 7 \\
\text { voltage }\end{array}$ & $\begin{array}{l}9.9 \pm 0.10 \\
\text { volts }\end{array}$ & 9.91 & $A$ & - & $\varphi$ \\
\hline 1.7 .3 .19 & $\begin{array}{l}\text { Channel } 7 \\
\text { voltage }\end{array}$ & $\begin{array}{l}0.3 \text { volts or } \\
\text { less }\end{array}$ & 0.21 & $A$ & & $p$ \\
\hline \multirow[t]{2}{*}{1.7 .3 .21} & $\begin{array}{l}\text { Drive and } \\
\text { directory }\end{array}$ & Record Value & $c: 1 d c t$ & A & & $p$ \\
\hline & File Name & Record Value & WEen LATA & $A$ & Aed & $p$ \\
\hline 1.7 .4 .4 & $\begin{array}{l}\text { Data } \\
\text { Channels } 1 \\
\text { through } 7\end{array}$ & $\begin{array}{l}\text { Match Figure } \\
\text { 2 profile } \\
\text { (Yes) } \\
\end{array}$ & $y=5$ & $A$ & $T . E .3$ & $p$ \\
\hline 1.7 .5 .3 & $\begin{array}{l}\text { Channel } 7 \\
\text { voitage }\end{array}$ & $\begin{array}{l}0.33(-0.00 \\
+0.02) \text { volts }\end{array}$ & 0.342 & $A$ & & $p$ \\
\hline 1.7 .5 .4 & $\begin{array}{l}\text { Channel } 1 \\
\text { voltage }\end{array}$ & $\begin{array}{l}0.4 \pm 0.05 \\
\text { volts }\end{array}$ & 0.400 & $A$ & & $p$ \\
\hline 1.7 .5 .5 & $\begin{array}{l}\text { Channel } 1 \\
\text { voltage }\end{array}$ & $\begin{array}{l}1.2 \pm 0.05 \\
\text { volts }\end{array}$ & 1.20 & $A$ & & $P$ \\
\hline 1.7 .5 .6 & $\begin{array}{l}\text { Channel } 1 \\
\text { voltage }\end{array}$ & $\begin{array}{l}2.0 \pm 0.05 \\
\text { volts }\end{array}$ & 2.00 & $A$ & & $p$ \\
\hline 1.7 .5 .7 & $\begin{array}{l}\text { CHAWUALLI } \\
\text { VOLTAGE }\end{array}$ & $\begin{array}{l}40 \text { vaLTS } \\
\text { OC LESSS }\end{array}$ & 0.00 & $A$ & TEF & $\vartheta$ \\
\hline
\end{tabular}


TEST DATA SHEET

\begin{tabular}{|c|c|c|c|c|c|c|}
\hline \multirow{2}{*}{\multicolumn{3}{|c|}{$\begin{array}{l}\text { Date of test: } \quad 9-25-25 \\
\text { Test section ritle: } \\
\text { Lass of } \text { bueles }\end{array}$}} & \multicolumn{4}{|c|}{ Test Unit Number: in $217 \sqrt{5}$} \\
\hline & & & \multirow{2}{*}{\multicolumn{4}{|c|}{$\begin{array}{l}\text { Equipnent Serial Mumber(s): } \\
752-45-08-001 \text { des } 4=28\end{array}$}} \\
\hline \multicolumn{3}{|c|}{$\begin{array}{l}\text { Test Performed By: } \\
\text { NoCed } \downarrow \text { L Leedy }\end{array}$} & & & & \\
\hline $\begin{array}{l}\text { Procedure Step } \\
\text { Number }\end{array}$ & Item & Range & value & $(A / R)$ & Comment & QA \\
\hline \multirow[t]{4}{*}{1.7 .5 .8} & $\begin{array}{l}\text { Channel } 2 \\
\text { voltage }\end{array}$ & $\begin{array}{l}0.4 \pm 0.05 \\
\text { voits }\end{array}$ & 0.40 & $A$ & & $P$ \\
\hline & $\begin{array}{l}\text { Channel } 2 \\
\text { voltage }\end{array}$ & $\begin{array}{l}1.2 \pm 0.05 \\
\text { volts }\end{array}$ & 1.20 & $A$ & & $p$ \\
\hline & $\begin{array}{l}\text { Channel } 2 \\
\text { voltage }\end{array}$ & $\begin{array}{l}2.0 \pm 0.05 \\
\text { volts }\end{array}$ & 2.00 & $A$ & & $p$ \\
\hline & $\begin{array}{l}\text { Channel } 2 \\
\text { voltage }\end{array}$ & $\begin{array}{l}0.4 \text { volts or } \\
\text { less }\end{array}$ & 0.00 & $A$ & & $P$ \\
\hline \multirow[t]{4}{*}{1.7 .5 .9} & $\begin{array}{l}\text { Channel } 3 \\
\text { voltage }\end{array}$ & $\begin{array}{l}0.4 \pm 0.05 \\
\text { volts }\end{array}$ & 0.40 & $A$ & & $\varphi$ \\
\hline & $\begin{array}{l}\text { Channel } 3 \\
\text { voltage }\end{array}$ & $\begin{array}{l}1.2 \pm 0.05 \\
\text { voits }\end{array}$ & 1.20 & $A$ & & $\varphi$ \\
\hline & $\begin{array}{l}\text { Channel } 3 \\
\text { voltage }\end{array}$ & $\begin{array}{l}2.0 \pm 0.05 \\
\text { volts }\end{array}$ & 2.00 & $A$ & & $p$ \\
\hline & $\begin{array}{l}\text { Channel } 3 \\
\text { voltage }\end{array}$ & $\begin{array}{l}0.4 \text { volts or } \\
\text { less }\end{array}$ & 0.00 & $A$ & & $p$ \\
\hline \multirow[t]{4}{*}{1.7 .5 .10} & $\begin{array}{l}\text { Channel } 4 \\
\text { voltage }\end{array}$ & $\begin{array}{l}0.4 \pm 0.05 \\
\text { volts }\end{array}$ & 0.40 & $A$ & & $\rho$ \\
\hline & $\begin{array}{l}\text { Channel } 4 \\
\text { voltage }\end{array}$ & $\begin{array}{l}1.2 \pm 0.05 \\
\text { volts }\end{array}$ & 1.20 & $A$ & & $p$ \\
\hline & $\begin{array}{l}\text { Channel } 4 \\
\text { voltage }\end{array}$ & $\begin{array}{l}2.0 \pm 0.05 \\
\text { volts }\end{array}$ & 2.00 & $A$ & & $p$ \\
\hline & $\begin{array}{l}\text { Channel } 4 \\
\text { voltage }\end{array}$ & $\begin{array}{l}0.4 \text { volts or } \\
\text { less }\end{array}$ & 0.00 & $A$ & & $p$ \\
\hline
\end{tabular}


TEST DATA SHEET

\begin{tabular}{|c|c|c|c|c|c|c|}
\hline \multirow{2}{*}{\multicolumn{3}{|c|}{$\begin{array}{l}\text { Date of test: } \quad 9-25-Q 5 \\
\text { Test section ritle: } \\
\text { Laxi of toulee }\end{array}$}} & \multicolumn{4}{|c|}{ Test unit Number: $S_{N} \bar{\alpha} / 7^{2}$} \\
\hline & & & \multirow{2}{*}{\multicolumn{4}{|c|}{$\begin{array}{l}\text { Equipment Serial Number(s): } \\
752-45-08 \text { cot dee } 428-46\end{array}$}} \\
\hline \multicolumn{3}{|c|}{$\begin{array}{l}\text { Test performed sy: } \\
\text { MOSAN L. LEECHA }\end{array}$} & & & & \\
\hline $\begin{array}{c}\text { Procedure Step } \\
\text { Nurber }\end{array}$ & Item & Range & value & $(A / R)$ & Comment & $Q A$ \\
\hline \multirow[t]{4}{*}{1.7 .5 .12} & $\begin{array}{l}\text { Channel } 5 \\
\text { voltage }\end{array}$ & $\begin{array}{l}0.4 \pm 0.05 \\
\text { volts }\end{array}$ & 0.40 & $A$ & & $p$ \\
\hline & $\begin{array}{l}\text { Channel } 5 \\
\text { voltage }\end{array}$ & $\begin{array}{l}1.2 \pm 0.05 \\
\text { volts }\end{array}$ & 1.20 & $A$ & & $y^{2}$ \\
\hline & $\begin{array}{l}\text { Channel } 5 \\
\text { voltage }\end{array}$ & $\begin{array}{l}2.0 \pm 0.05 \\
\text { volts }\end{array}$ & 2.00 & $A$ & & $V$ \\
\hline & $\begin{array}{l}\text { Channel } 5 \\
\text { voltage }\end{array}$ & $\begin{array}{l}0.4 \text { volts or } \\
\text { less }\end{array}$ & 0.00 & $A$ & & $\varphi$ \\
\hline 1.7 .5 .13 & $\begin{array}{l}\text { Channel } 6 \\
\text { voltage }\end{array}$ & $\begin{array}{l}0.1 \pm 0.05 \\
\text { volts }\end{array}$ & 0.10 & 17 & & 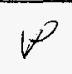 \\
\hline 1.7 .5 .14 & $\begin{array}{l}\text { Channel } 6 \\
\text { voltage }\end{array}$ & $\begin{array}{l}3.0 \pm 0.05 \\
\text { volts }\end{array}$ & 3.00 & $A$ & . & $\varphi$ \\
\hline 1.7 .5 .15 & $\begin{array}{l}\text { Channel } 6 \\
\text { voltage }\end{array}$ & $\begin{array}{l}5.8 \pm 0.05 \\
\text { voits }\end{array}$ & 5.80 & $A$ & & $\varphi$ \\
\hline 1.7 .5 .16 & $\begin{array}{l}\text { Channel } 6 \\
\text { voltage }\end{array}$ & $\begin{array}{l}0.1 \text { volts or } \\
\text { less }\end{array}$ & 0.00 & $A$ & & $\varphi$ \\
\hline 1.7 .5 .17 & $\begin{array}{l}\text { Channel } 7 \\
\text { voltage }\end{array}$ & $\begin{array}{l}5.0 \pm 0.10 \\
\text { volts }\end{array}$ & 5.00 & $A$ & & $\omega$ \\
\hline 1.7 .5 .18 & $\begin{array}{l}\text { Channel } 7 \\
\text { voltage }\end{array}$ & $\begin{array}{l}9.9 \pm 0.10 \\
\text { volts }\end{array}$ & 9.89 & $A$ & & $\infty$ \\
\hline 1.7 .5 .19 & $\begin{array}{l}\text { Channel } 7 \\
\text { voltage }\end{array}$ & $\begin{array}{l}0.3 \text { volts or } \\
\text { less }\end{array}$ & 0.20 & $A$ & & P \\
\hline 1.7 .5 .24 & $\begin{array}{l}\text { Data } \\
\text { Channels } 1 \\
\text { through } 7\end{array}$ & $\begin{array}{l}\text { Match Figure } \\
2 \text { profile } \\
\text { (Yes) }\end{array}$ & $y \in S$ & $A$ & & 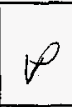 \\
\hline 1.7 .6 .1 & Section 1.7 & $\begin{array}{l}\text { Complete } \\
\text { (Yes) }\end{array}$ & $y \in S$ & $A$ & - & $p$ \\
\hline 1.8 .1 .1 & Section 1.7 & $\begin{array}{l}\text { Complete } \\
\text { (Yes) }\end{array}$ & $\varphi \in S$ & $A$ & & $k \omega$ \\
\hline 1.8 .2 .1 & $\begin{array}{l}\text { Section } \\
1.8 .1\end{array}$ & $\begin{array}{l}\text { Complete } \\
\text { (Yes) }\end{array}$ & $T E-46$ & $A$ & $\begin{array}{l}\text { Nanic Plate } \\
\text { instacleo }\end{array}$ & $K v$ \\
\hline
\end{tabular}


TEST DATA SHEET

\begin{tabular}{|c|c|c|c|c|c|c|}
\hline \multirow{2}{*}{\multicolumn{3}{|c|}{$\begin{array}{l}\text { Date of test: } 9-25-95 \\
\text { Test section Title: }\end{array}$}} & \multicolumn{4}{|c|}{ Test Unit Munber: $5 \lambda 121255$} \\
\hline & & & \multirow{2}{*}{\multicolumn{4}{|c|}{$\begin{array}{l}\text { Equipnent Serial Mumber(s): } \\
817-23-01-005 \text { oue } 12.19 .95 \\
752-45-08-001 \text { Jue } 4-28-96 \\
817-23-01-0090067-12-96 \\
817-45-08-051 \text { oue } 11-16.95\end{array}$}} \\
\hline \multicolumn{3}{|c|}{$\begin{array}{r}\text { Test Performed By: } \\
\text { NOCM J. LEECA }\end{array}$} & & & & \\
\hline $\begin{array}{l}\text { Procedure Step } \\
\text { Wumber }\end{array}$ & Item & Range & value & $(A / R)$ & Comment & aA \\
\hline 1.8 .2 .1 & $\begin{array}{l}\text { Section } \\
1.8 .1\end{array}$ & $\begin{array}{l}\text { Complete } \\
\text { (Yes) }\end{array}$ & $Y \in S$ & & $T E-6$ & KW \\
\hline 1.8 .2 .10 & $\begin{array}{l}\text { Report } \\
\text { Schedule }\end{array}$ & Record Value & $\begin{array}{l}\text { ZX,A ACTIVES } \\
\text { HALTED }\end{array}$ & A & & Ka \\
\hline 1.8 .3 .1 & $\begin{array}{l}\text { Section } \\
1.8 .2\end{array}$ & $\begin{array}{l}\text { Complete } \\
\text { (Yes) }\end{array}$ & $y \in s$ & $A$ & & $k w$ \\
\hline 1.8 .3 .2 & VFO Power & OFF & oft & A & & $K K_{N}$ \\
\hline 1.8 .3 .6 & $\begin{array}{l}\text { DL Channel } \\
6\end{array}$ & $\begin{array}{l}3.0 \pm 0.10 \\
\text { volts }\end{array}$ & $3.00 \mathrm{~V}$ & $A$ & & $K w$ \\
\hline 1.8 .3 .7 & $\begin{array}{l}\text { DL Channel } \\
7\end{array}$ & $\begin{array}{l}0.33,-0.00 \\
+0.02 \text { volts }\end{array}$ & $\begin{array}{l}3300 \mathrm{~V} \\
.3400 \mathrm{~V}\end{array}$ & A & $\bar{T} \epsilon-7$ & $K \omega$ \\
\hline 1.8 .3 .12 & $\begin{array}{l}\text { OL Channel } \\
\text { l }\end{array}$ & $\begin{array}{l}1.2 \pm 0.05 \\
\text { volts }\end{array}$ & $1.20 \mathrm{~V}$ & A & & $K_{v}$ \\
\hline 1.8 .3 .13 & $\begin{array}{l}\text { DL Channel } \\
7\end{array}$ & $\begin{array}{l}0.33,-0.00 \\
+0.02 \text { voits }\end{array}$ & $.340 \mathrm{~V}$ & A & & $k w$ \\
\hline 1.8 .3 .18 & $\begin{array}{l}\text { DL Channel } \\
2\end{array}$ & $\begin{array}{l}1.2 \pm 0.05 \\
\text { volts }\end{array}$ & $1.200 \mathrm{~V}$ & A & & Kw \\
\hline 1.8 .3 .19 & $\begin{array}{l}\mathrm{DL} \text { Channel } \\
\end{array}$ & $\begin{array}{l}0.33,-0.00, \\
+0.02 \text { voits } \\
\end{array}$ & $.3400 \mathrm{~V}$ & A & & $K_{w}$ \\
\hline 1.8 .3 .24 & $\begin{array}{l}\text { DL Channel } \\
3\end{array}$ & $\begin{array}{l}1.2 \pm 0.05 \\
\text { volts }\end{array}$ & $1.200 \mathrm{~V}$ & A & & $k \omega$ \\
\hline 1.8 .3 .25 & $\underset{7}{D L}$ Channel & $\begin{array}{l}0.33,-0.00, \\
+0.02 \text { volts }\end{array}$ & $.3400 \mathrm{~V}$ & $A$ & & $K w$ \\
\hline 1.8 .3 .30 & $\begin{array}{l}\text { DL Channel } \\
4\end{array}$ & $\begin{array}{l}1.2 \pm 0.05 \\
\text { volts }\end{array}$ & $1.20 \mathrm{~V}$ & $A$ & - & $K w$ \\
\hline 1.8 .3 .31 & $\begin{array}{l}\text { DL Channe } 1 \\
7\end{array}$ & $\begin{array}{l}0.33,-0.00 \\
+0.02 \text { voits } \\
\end{array}$ & $.3400 \mathrm{~V}$ & A & & $k w$ \\
\hline 1.8 .3 .36 & $\begin{array}{l}\text { DL Channel } \\
5\end{array}$ & $\begin{array}{l}1.2 \pm 0.05 \\
\text { voits }\end{array}$ & $1.20 \mathrm{~V}$ & A & & $k \omega$ \\
\hline
\end{tabular}


WHC-SD-WM-ATR-149

Revision $O$

TEST DATA SHEET

\begin{tabular}{|c|c|c|c|c|c|c|}
\hline Date of test: & \multicolumn{2}{|l|}{$9-2 \div-25$} & \multicolumn{4}{|c|}{ Test Unit Number: $2 \propto / 1 / 55$} \\
\hline \multicolumn{3}{|c|}{ Test Section Title: } & \multirow{2}{*}{\multicolumn{4}{|c|}{$\begin{array}{l}\text { Equipment Serial Nunber(s): } \\
817-23-01-005 \text { Due 12-19-45 } \\
752-\$ 5-08 \text { OOI DUE \&f je } 96 \\
817-23-01-\infty 07 \text { Due } 7-12-96 \\
817-45-08-051 \text { Due } 11-16-45\end{array}$}} \\
\hline \multicolumn{3}{|c|}{$\begin{array}{l}\text { Test performed By: } \\
\text { ITOCA } 1 . \text { LEECH }\end{array}$} & & & & \\
\hline $\begin{array}{l}\text { Procedure step } \\
\text { Number }\end{array}$ & Item & Range & value & $(A / R)$ & comment & OA \\
\hline 1.8 .3 .37 & $\begin{array}{l}\text { DL Channel } \\
7\end{array}$ & $\begin{array}{l}0.33,-0.00 \\
+0.02 \text { voits }\end{array}$ & $.340^{2} \mathrm{~V}$ & A & & $k-v$ \\
\hline 1.8 .3 .41 & $\begin{array}{l}\text { DL Channel } \\
7\end{array}$ & $\begin{array}{l}5.0 \pm 0.1 \\
\text { volts }\end{array}$ & $5.00 \mathrm{~V}$ & $A$ & & $K \omega$ \\
\hline \multirow[t]{2}{*}{1.8 .3 .46} & $\begin{array}{l}\text { Drive and } \\
\text { Directory }\end{array}$ & Record Value & C. $\backslash 0 C P \backslash D C P$ & Paita $A$ & & $K w$ \\
\hline & File Name & Record Value & \multicolumn{2}{|c|}{ CAMIDAT.PRN A } & & $K w$ \\
\hline 1.8 .4 .4 & $\begin{array}{l}\text { Data } \\
\text { Channels } 1 \\
\text { through } 7\end{array}$ & $\begin{array}{l}\text { Match Figure } \\
3 \text { profile } \\
\text { (Yes) }\end{array}$ & $\begin{array}{l}1-4 \quad Y \in S \\
6-7 \quad Y \in S \\
5 \text { S\&E } \quad r \in-10\end{array}$ & $A$ & $T E-10$ & Ka \\
\hline 1.8 .5 .1 & Section 1.8 & $\begin{array}{l}\text { Complete } \\
\text { (Yes) }\end{array}$ & YES & $A$ & & KW \\
\hline
\end{tabular}


WHC-SD-WM-ATR-149

Revision 0

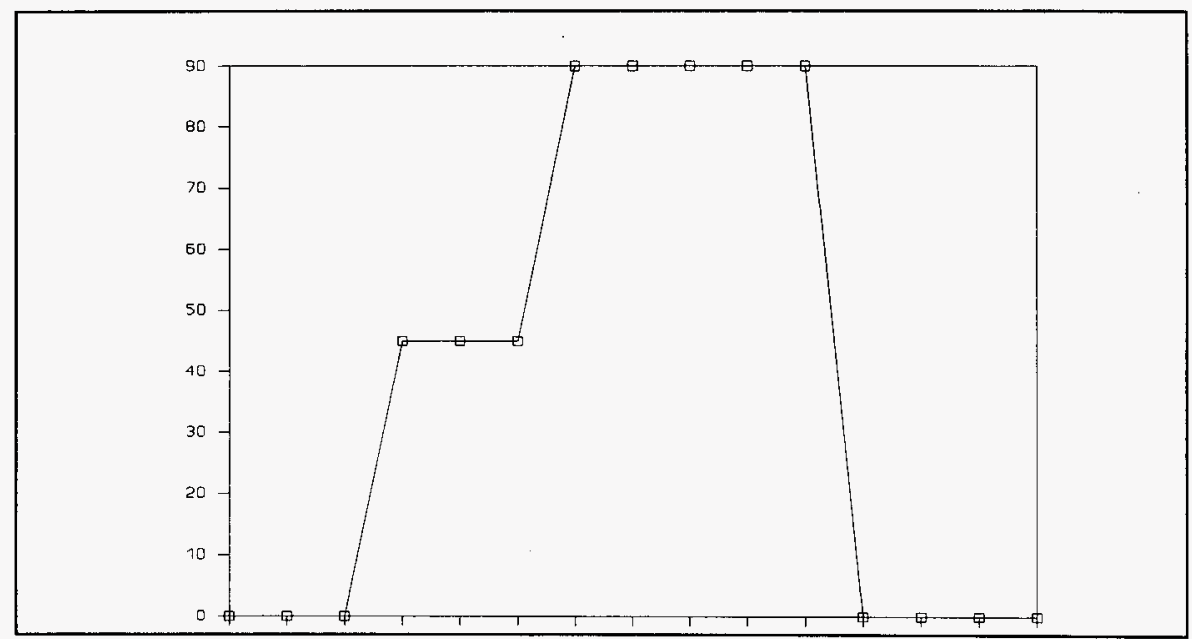

Graph 1: Channel 1 data collected during Section 1.7.3, Normal Operation

Channel $l$ is Motor Power

Vertical scale is $\mathrm{kW}$ (Range is $0-9 \mathrm{~kW}$ )

Horizontal scale is time (5 sec/division)

$\square=$ data point

Comments: Matches Figure 2 criteria. 


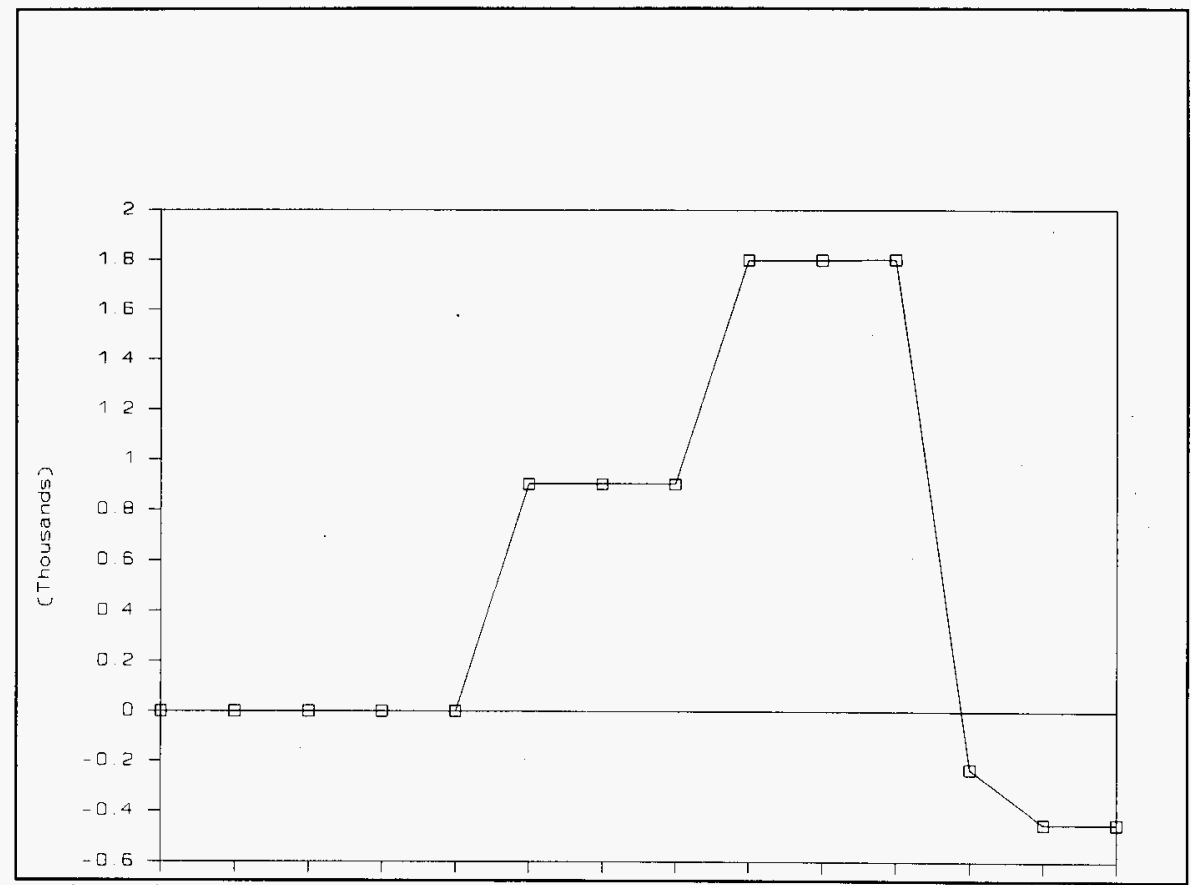

Graph 2: Channel 2 data collected during Section 1.7.3, Normal Operation

Channel 2 is Motor RPM

Vertical scale is RPM (Range is $0-1800$ RPM)

Horizontal scale is time ( $5 \mathrm{sec} /$ division)

$\square=$ data point

Comments: While figure 2 shows the right most data points as being at zero, the procedure says to reduce the voltage to 0.4 volts or less. During the test the datalogger input was usually grounded, thus resulting in the "Negative" values shown. This-is acceptable. 


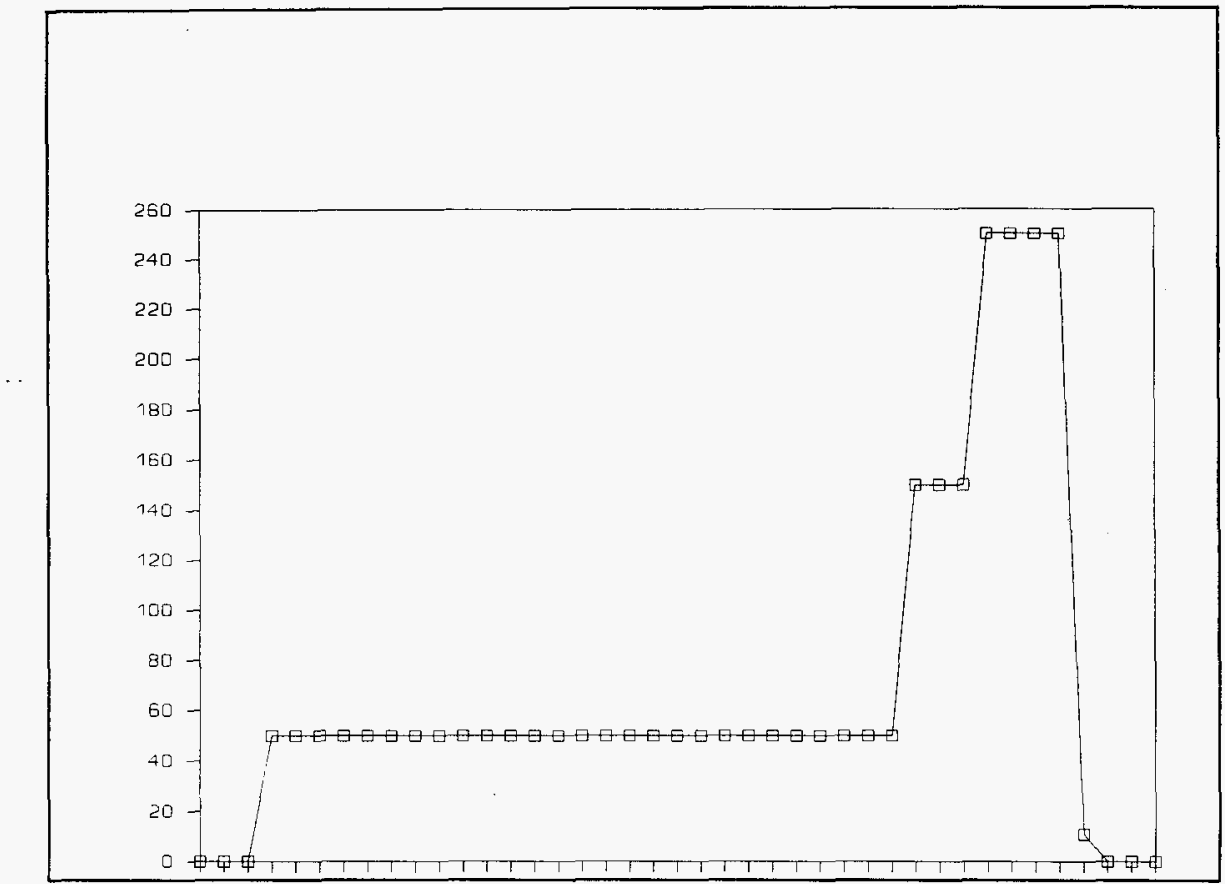

Graph 3: Channel 3 data collected during Section 1.7.3, Normal Operation

Channel 3 is Motor Temperature

Vertical scale is degrees $F$ (Range is 0 -250 degress $F$ )

Horizontal scale is time (5 sec/division)

= data point

Comments: The first three (3) data points are for an input of 0.0 volts. The following 27 data points are for an input of 0.4 volts, per the procedure. The first 27 data points were inadvertently shown in this graph. The third to last data point is a transition voltage recorded as the input was being changed from 2.0 volts to 0.0 volts. 


\section{WHC-SD-WM-ATR-149 \\ Revision 0}

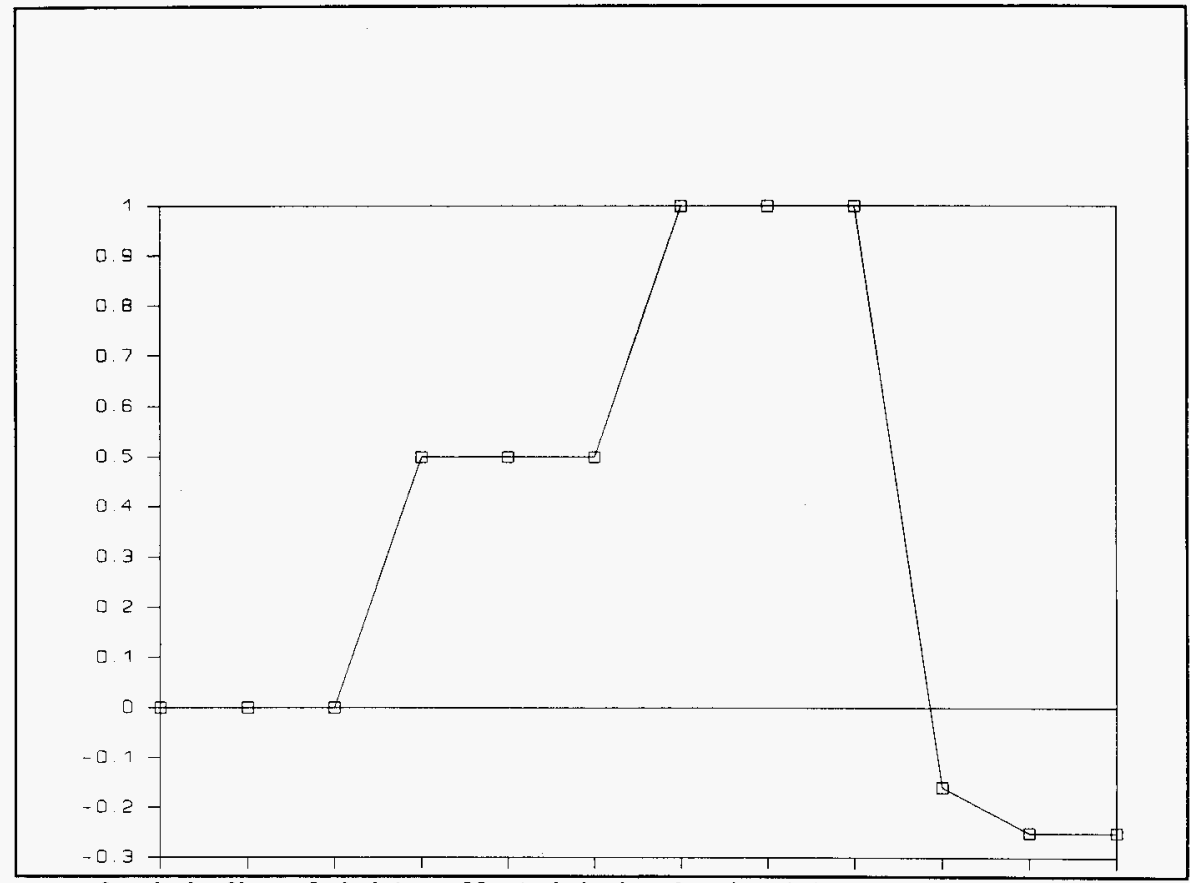

Graph 4: Channel 4 data collected during Section 1.7.3, Normal Operation

Channel 4 is Pump Column Vibration

Vertical scale is inch/sec (Range is $0-1.0$ inch/sec)

Horizontal scale is time ( $5 \mathrm{sec} /$ division)

$=$ data point

Comments: While Figure 2 shows the right most data points as being at zero, the procedure says to reduce the voltage to 0.4 volts or less. During the test the datalogger input was usually grounded, thus resulting in the "Negative" values shown. This is acceptable. 


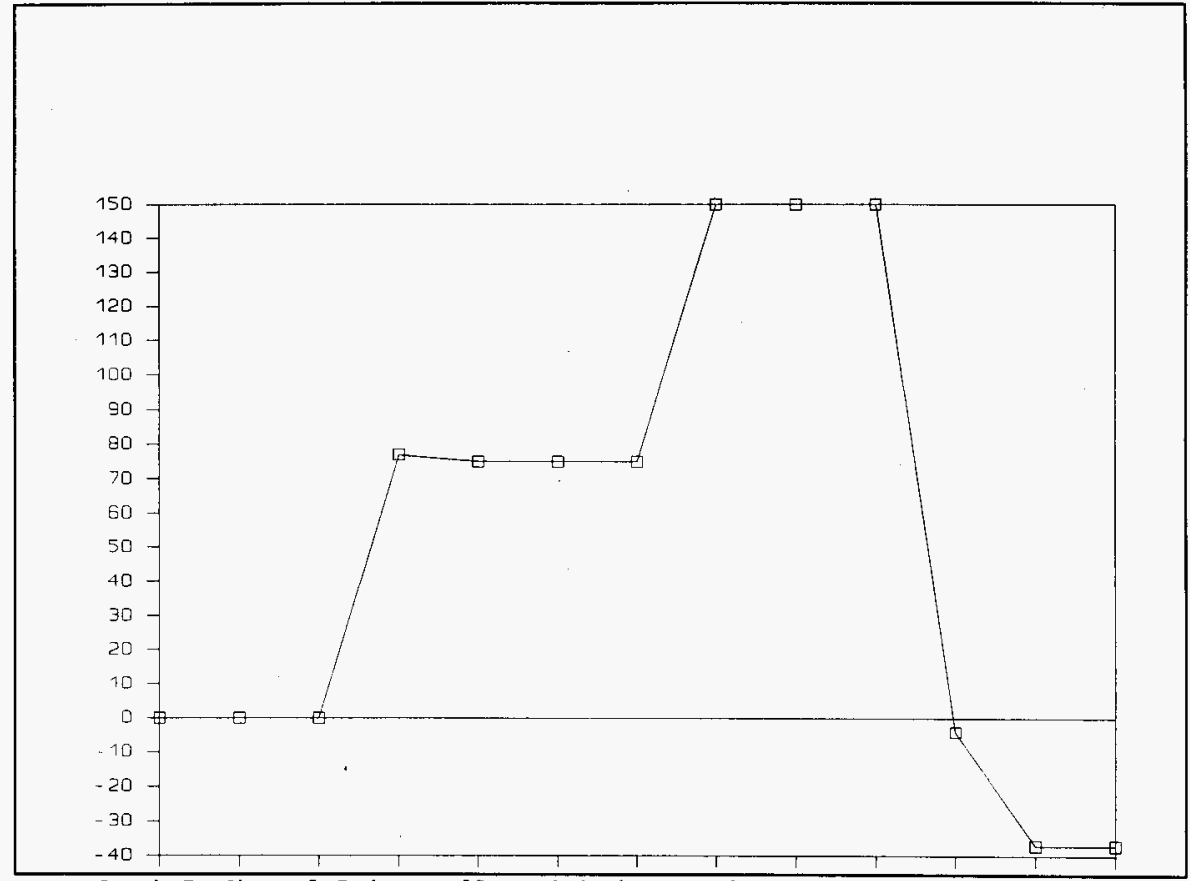

Graph 5: Channel 5 data collected during Section 1.7.3, Normal Operation

Channel 5 is Pump Column Strain

Vertical scale is Pounds (Range is $0-150$ lbs)

Horizontal scale is time (5 sec/division)

$\square=\operatorname{data}$ point

Comments: While Figure 2 shows the right most data points as being zero, the procedure says to reduce the voltage to 0.4 volts or less. During the test the datalogger input was usually grounded, thus resulting in the "Negative" values shown. This is acceptable. Also, the forth data point is a transition voltage recorded while the input was being changed from 0.4 volt to 1.2 volts. 


\section{WHC-SD-WM-ATR-149}

Revision 0

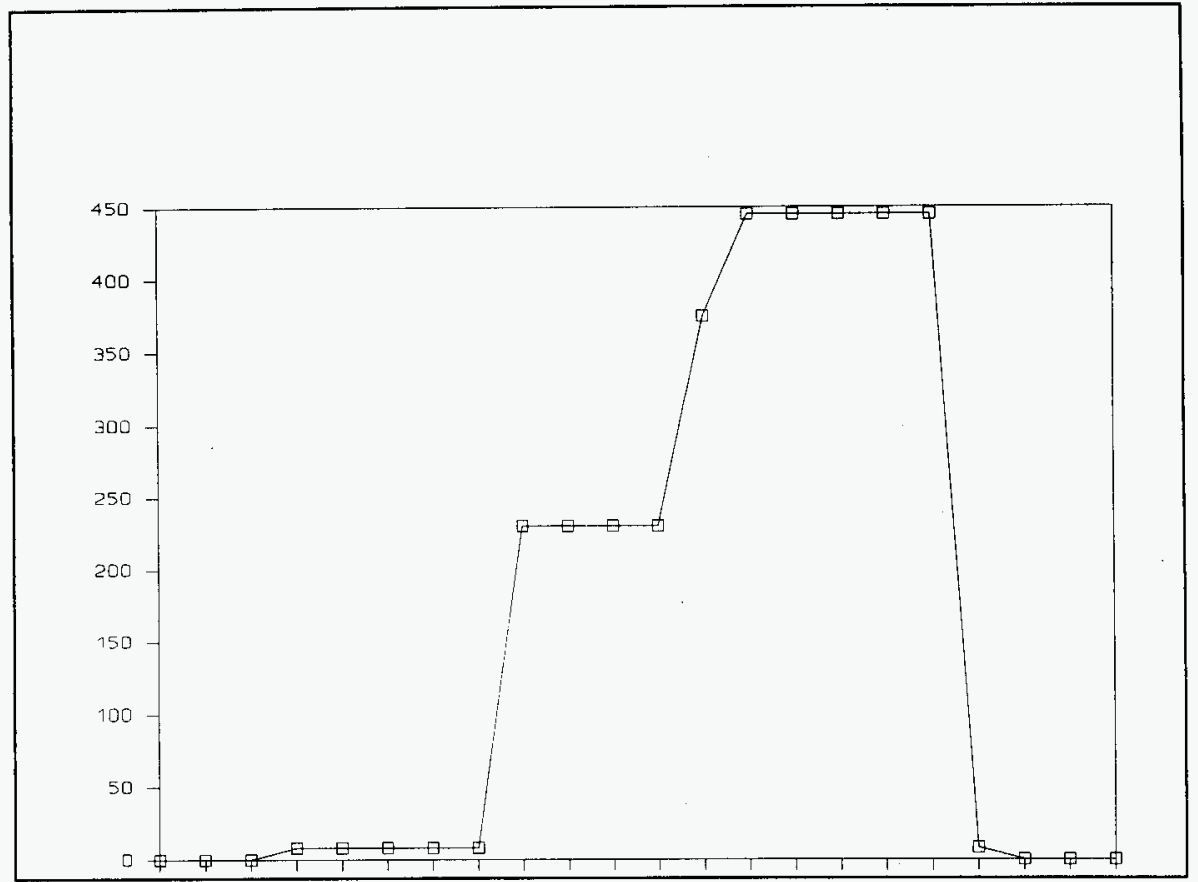

Graph 6: Channel 6 data collected during Section 1.7.3, Normal Operation

Channel 6 is Motor Voltage

Vertical scale is Volts (Range is $0-460$ volts)

Horizontal scale is time (5 sec/division)

$=$ data point

Comments: The slight increase after the third data point is where 0.1 volt was applied to the datalogger input per the procedure. Transitional data points were recorded between the mid-scale and full-scale change and between the full-scale and low-scale change. This is acceptable. 


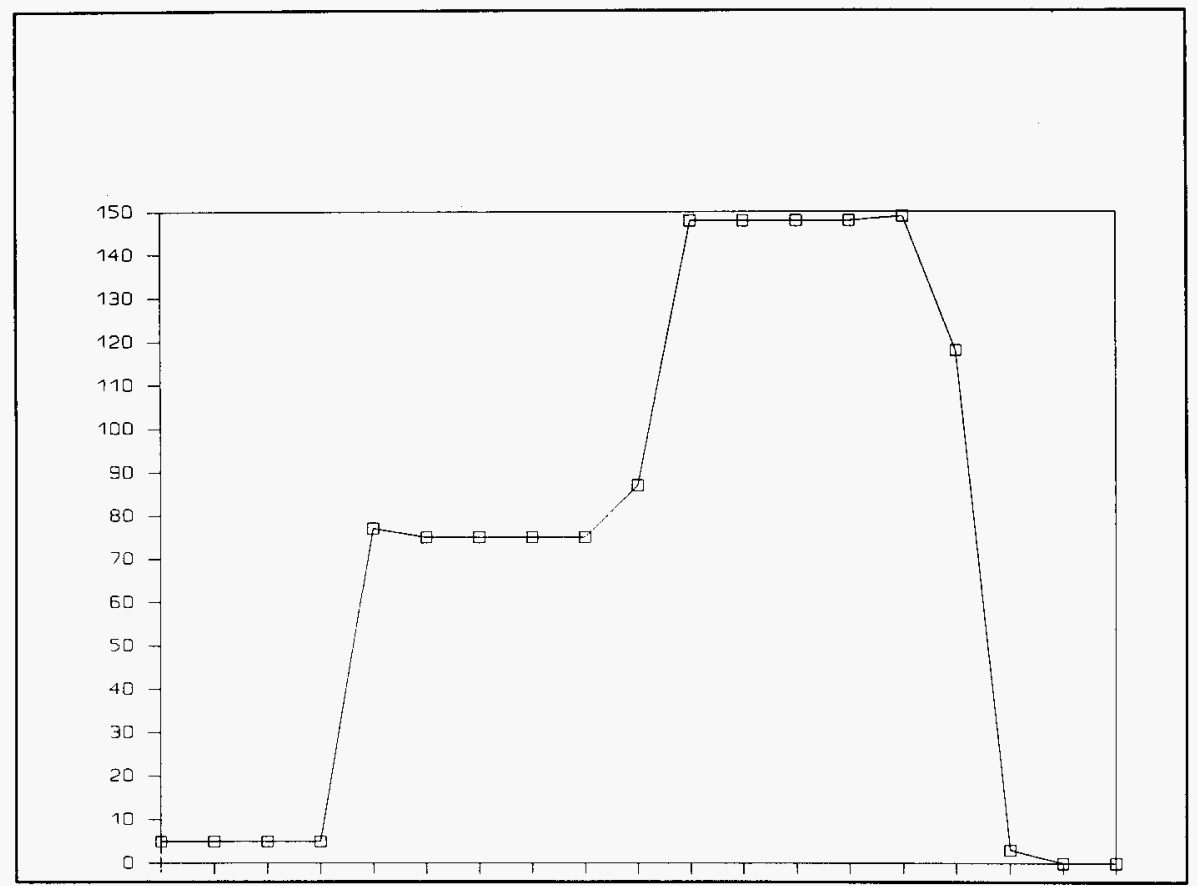

Graph 7: Channel 7 data collected during Section 1.7.3, Normal Operation

Channel 7 is Motor Torque

Vertical scale is \% Ful1 Load (Range is $0-150 \%$ )

Horizontal scale is time ( $5 \mathrm{sec} /$ division)

= data point

Comments: Transitional data points were recorded between the low to mid scale change, the mid to full scale change, and the full-low scale change. While Figure 2 shows the right most data points as being zero, the procedure says to reduce the voltage to 0.4 volts or less. The second to last data point is less than 0.4 volts, but is not 0.0 volts (nominal) like the last two (2). This is acceptable. 


\section{Revision 0}

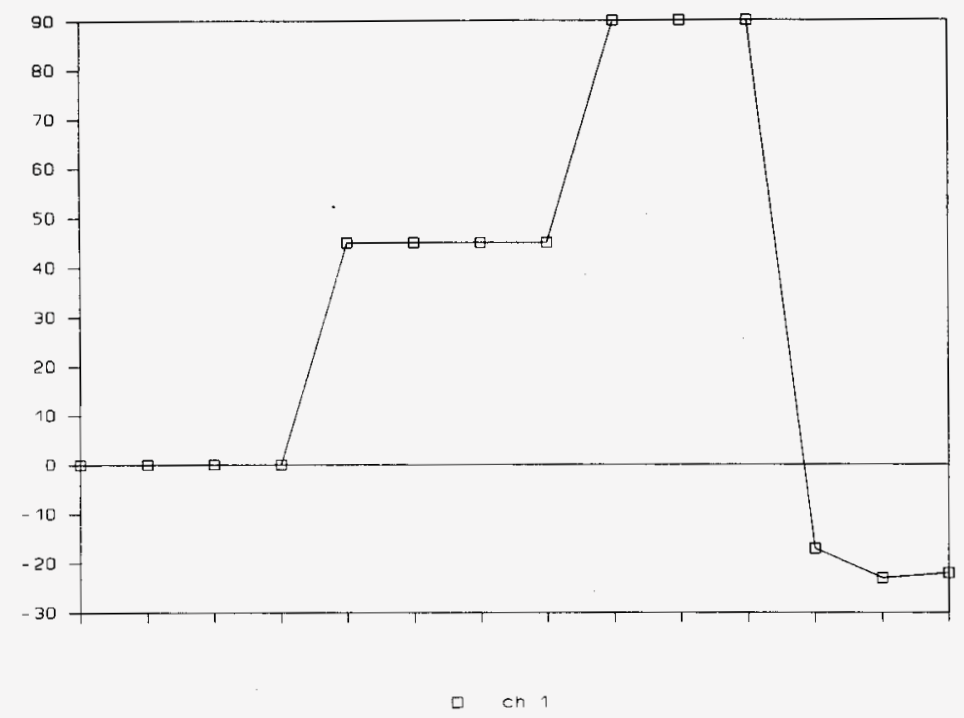

Graph 8: Channel 1 data collected during Section 1.7.5, Loss of Power

Channel 1 is Motor Power

Vertical scale is $\mathrm{kW}$

Horizontal scale is time (5 sec/division)

= data point

Comments: While Figure 2 shows the right most data points as being zero, the procedure says to reduce the voltage to 0.4 volts or less. During the test the datalogger input was usually grounded, thus resulting in the "Negative" values shown. This is acceptable. 


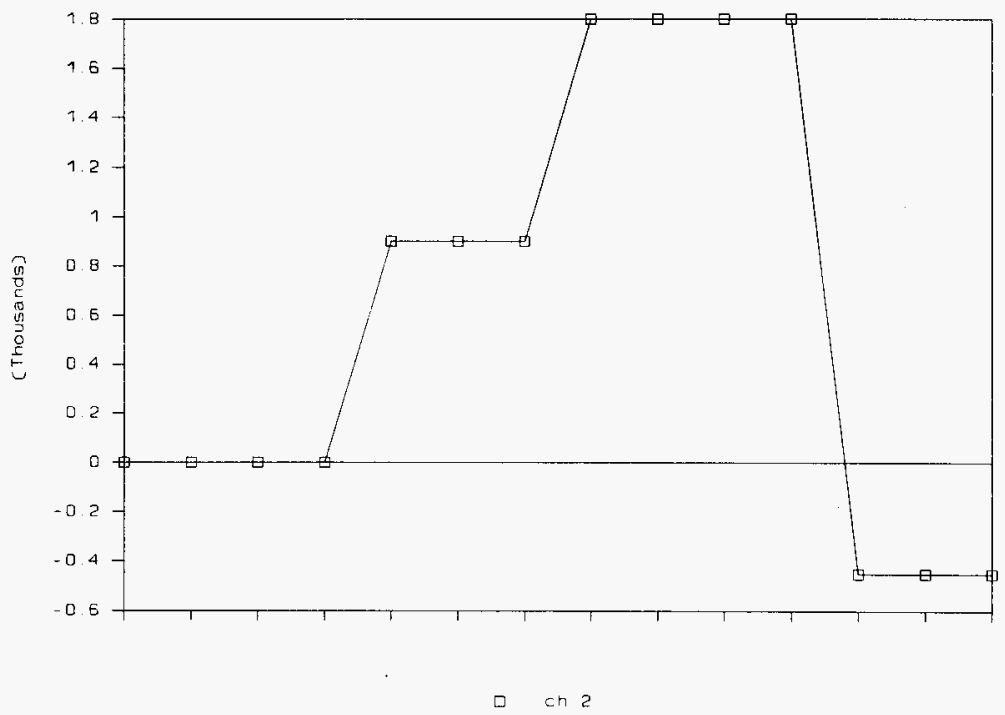

Graph 9: Channel 2 data collected during Section 1.7.5, Loss of Power

\section{Channe 2 is Motor RPM}

Vertical scale is Thousands RPM

Horizontal scale is time (5 $\mathrm{sec} /$ division)

$\square=$ data point

Comments: While Figure 2 shows the right most data points as being zero, the procedure says to reduce the voltage to 0.4 volts or less. During the test the datalogger input was usually grounded, thus resulting in the "Negative" values shown. This is acceptable. 


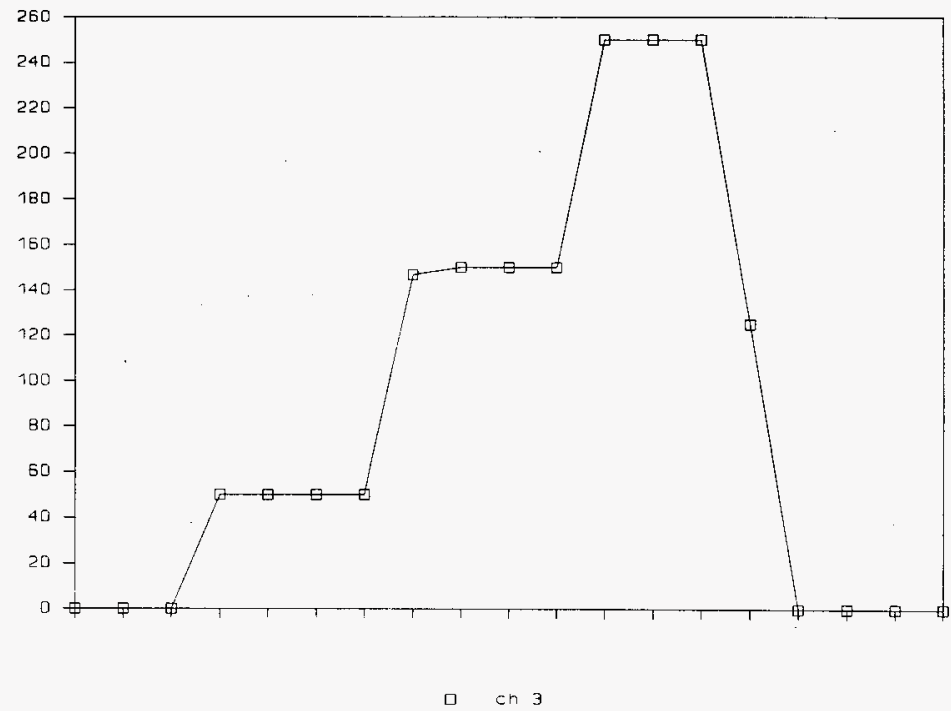

Graph 10: Channe1 3 data collected during Section 1.7.5, Loss of Power

Channel 3 is Motor Temperature

Vertical scale is degrees $F$

Horizontal scale is time ( $5 \mathrm{sec} /$ division)

$\square=$ data point

Comments: The first three (3) data points are for an input of 0.0 volts. The following four (4) data points are for an input of 0.4 volts, per the procedure. Transitional data points were recorded between the low to mid-scale change, and the full $=1$ ow scale change. While Figure 2 shows the right most data points as being zero, the procedure says to reduce the voltage to 0.4 volts or less. During the test the datalogger input was usually grounded, thus resulting in the "Negative" values shown. This is acceptable. 


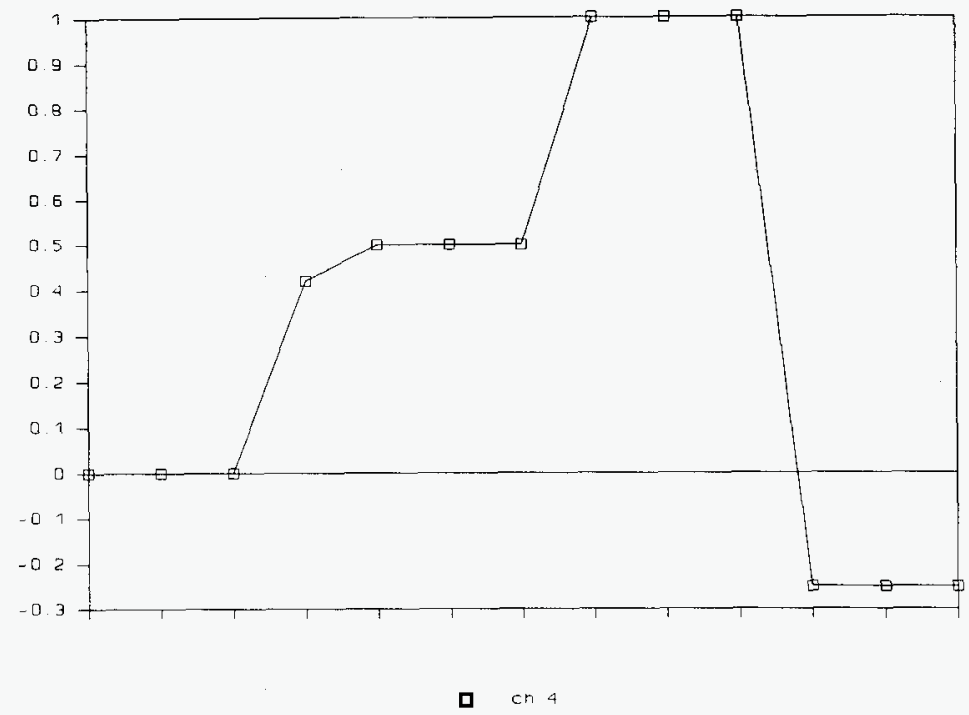

Graph 11: Channel 4 data collected during Section 1.7.5, Loss of Power

Channel 4 is Pump Column Vibration

Vertical scale is inch/sec

Horizontal scale is time (5 sec/division)

$=$ data point

Comments: While Figure 2 shows the right most data points as being zero, the procedure says to reduce the voltage to 0.4 volts or less. During the test the datalogger input was usually grounded, thus resulting in the "Negative" values shown. This is acceptable. Also, the forth data point is a transition voltage recorded while the input was being changed from 0.4 volt to 1.2 volts.

Note: After this data was recorded power was removed from the datalogger for about one (1) minute. 


\section{WHC-SD-WM-ATR-149}

Revision 0

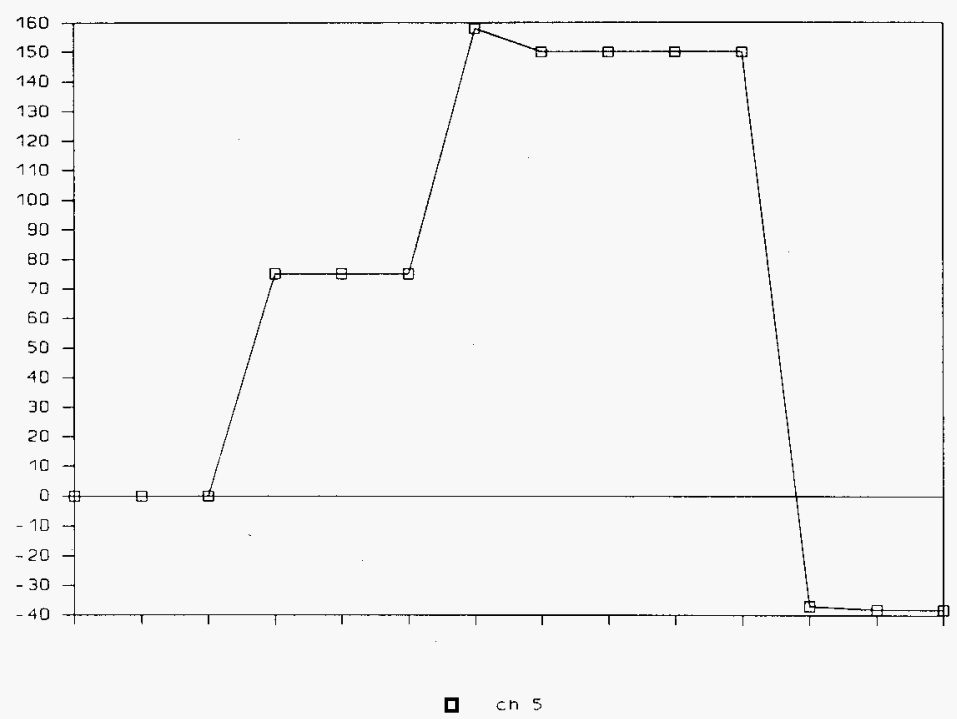

Graph 12: Channel 5 data collected during Section 1.7.5, Loss of Power

Channel 5 is Pump Column Strain

Vertical scale is Pounds

Horizontal scale is time ( $5 \mathrm{sec} /$ division)

= data point

Comments: While Figure 2 shows the right most data points as being zero, the procedure says to reduce the voltage to 0.4 volts or less. During the test the datalogger input was usually grounded, thus resulting in the "Negative" values shown. This is acceptable. Also, the forth data point is a transition voltage recorded while the input was being changed from 0.4 volt to 1.2 volts. 


\section{WHC-SD-WM-ATR-149}

Revision 0

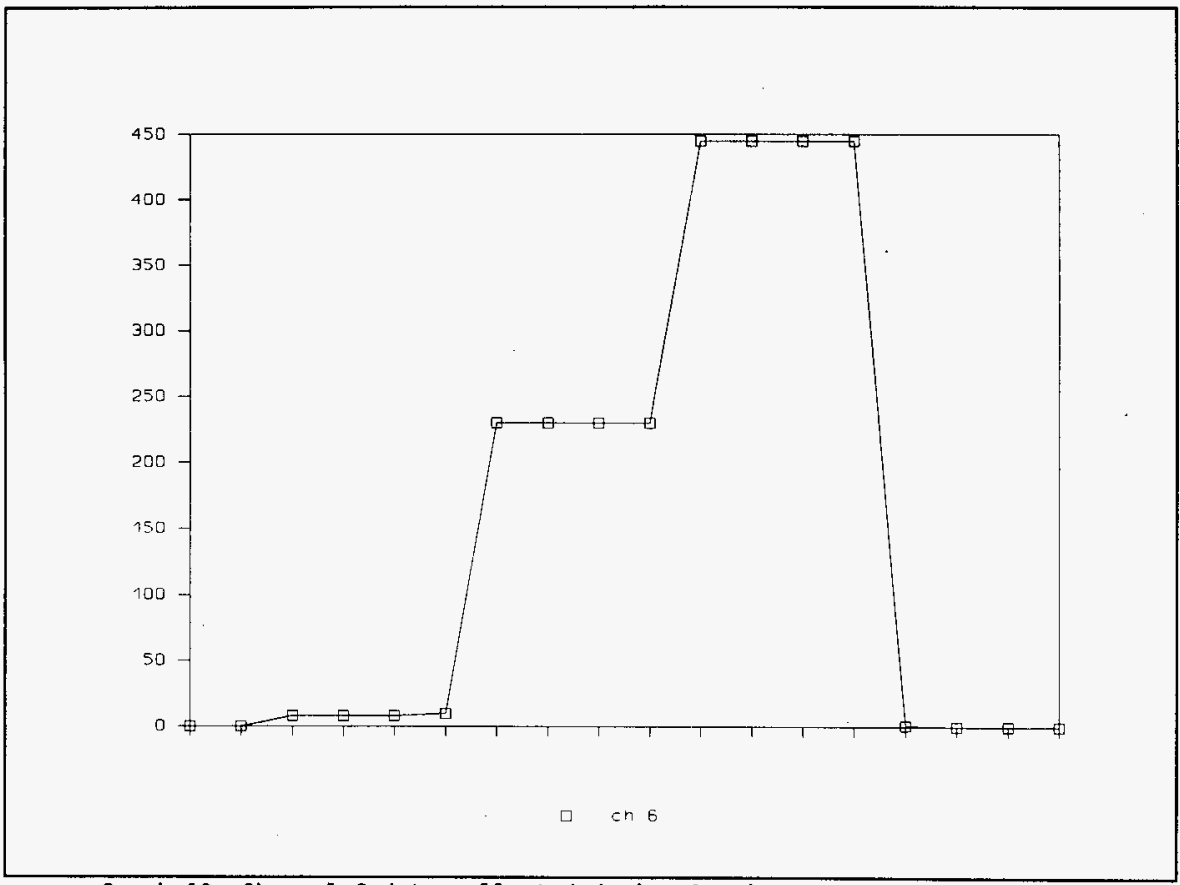

Graph 13: Channel 6 data collected during Section 1.7.5, Loss of Power

Channel 6 is Motor Voltage

Vertical scale is Volts

Horizontal scale is time (5 sec/division)

= data point

Comments: The slight increase after the second data point is where 0.1 volt was applied to the datalogger input per the test procedure. 


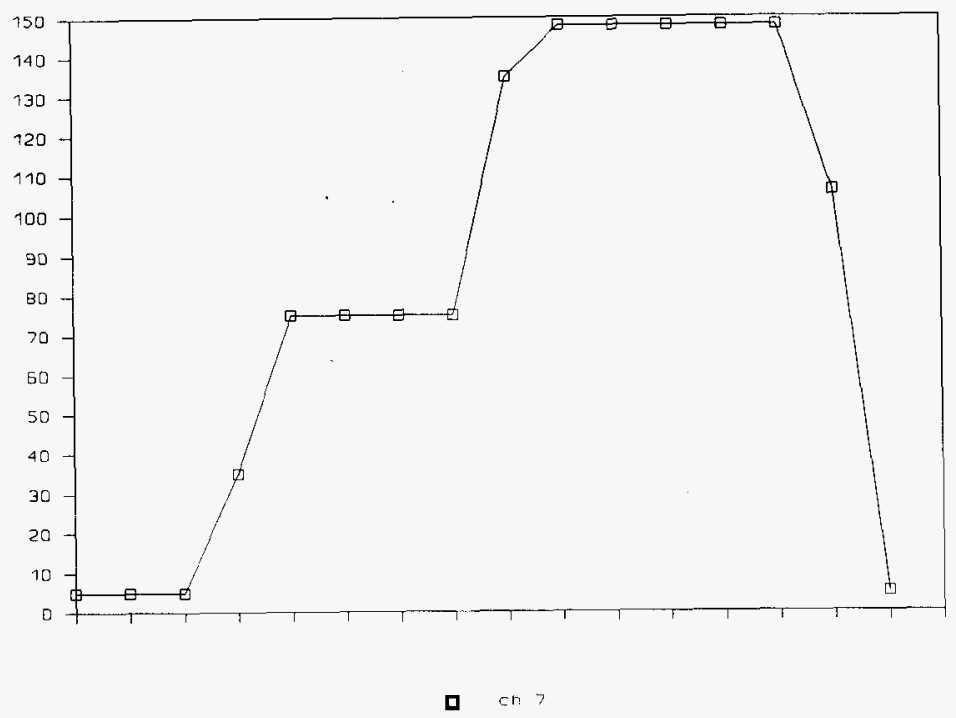

Graph 14: Channel 7 data collected during Section 1.7.5, Loss of Power

Channel 7 is Motor Torque

Vertical scale is \% Full Load

Horizontal scale is time ( $5 \mathrm{sec} /$ division)

$=$ data point

Comments: Transitional data points were recorded between the low to mid scale change, the mid to full scale change, and the full-low scale change. While figure 2 shows the three

(3) right most data points as being zero, the procedure says to reduce-the voltage to less than 0.4 volts, which is below the setpoint which causes the datalogger to cease recording, thus there are not three (3) low-scale data points. This is acceptable. 
Datalogger ATP/OTP

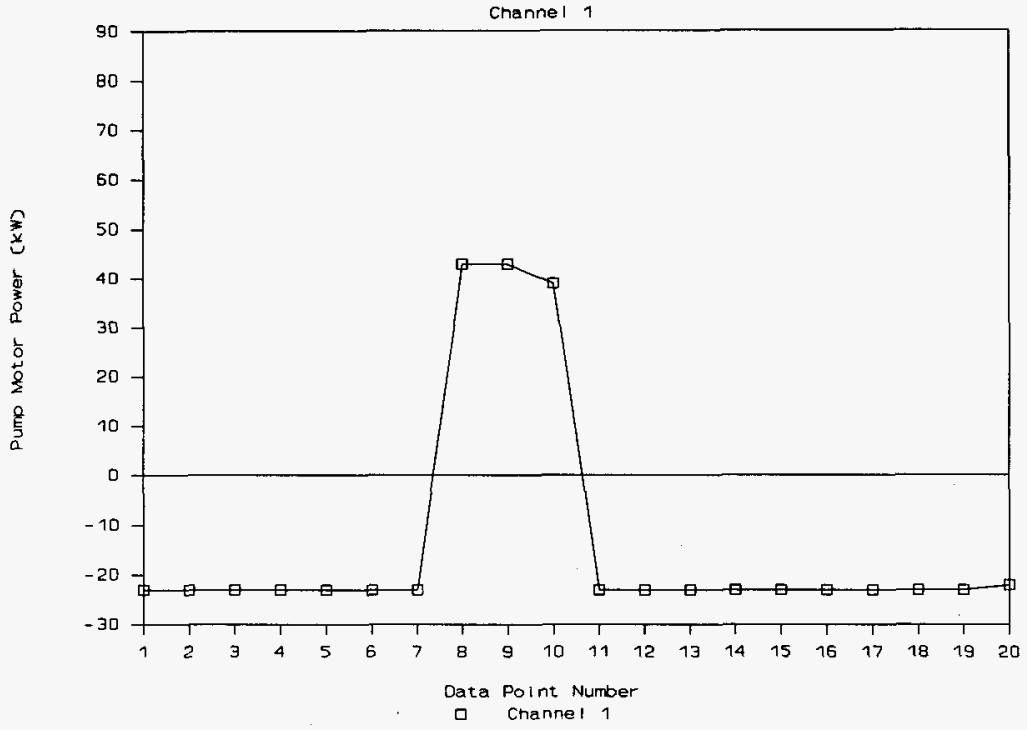

Graph 15: Channel 1 data collected during Section 1.8

Channel 1 is Motor Power

Vertical scale is $\mathrm{kW}$ (Range is $0-9 \mathrm{~kW}$ )

Horizontal scale is time (data point number)

$=$ data point

Comments: Data Points $8 \& 9$ are the two points associated with Steps 1.8.3.13 \& 1.8.3.14. These are clearly seen to be at mid-range, as expected. The -23 reading for all other readings (except \#10 - a spurious reading) is the data loggers attempt to scale a zero $\mathrm{mA}$ input on a 4-20 mA input. This is acceptable and matches Figure 3 criteria. 


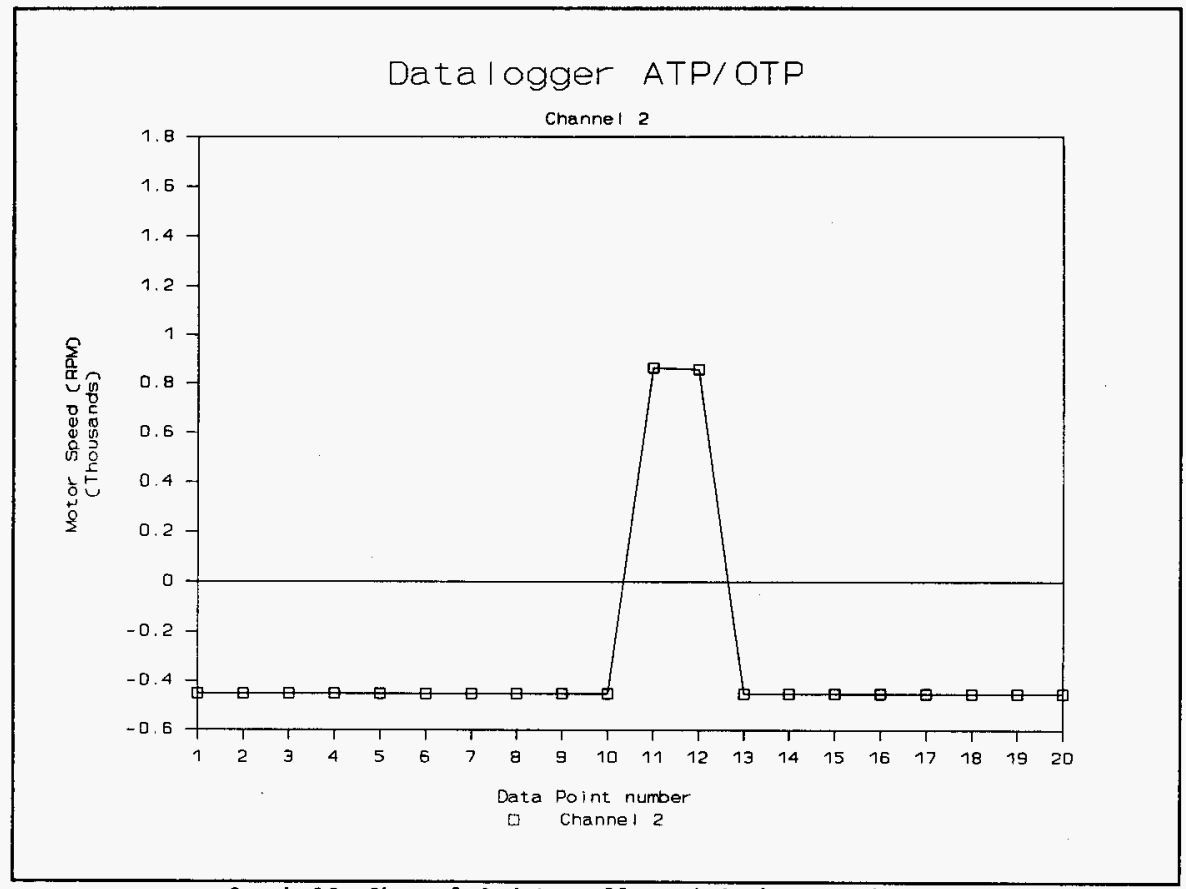

Graph 16: Channel 2 data collected during Section 1.8

Channel 2 is Motor RPM

Vertical scale is RPM (Range is $0-1800$ RPM)

Horizontal scale is time (data point number)

= data point

Comments: Data Points $11 \& 12$ are the two points associated with Steps 1.8 .3 .19 \&

1.8.3.20. These are clearly seen to be at mid-range, as expected. The -0.43 reading for all other readings is the data loggers attempt to scale a zero $\mathrm{mA}$ input on a 4-20 $\mathrm{mA}$ input. This is acceptable and matches Figure 3 criteria. 
Revision 0

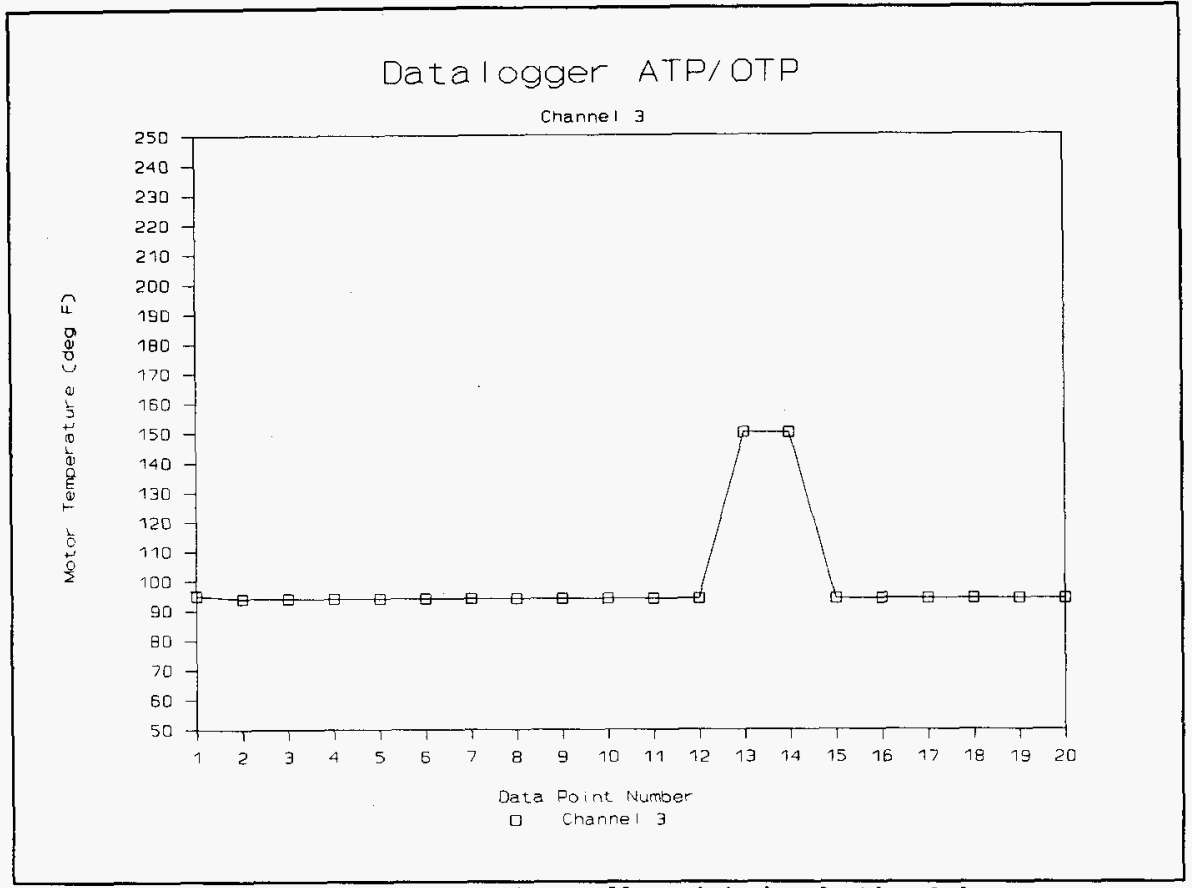

Graph 17: Channel 3 data collected during Section 1.8

Channe 3 is Motor Temperature

Vertical scale is degrees $F$ (Range is 0 -250 degress $F$ )

Horizontal scale is time (data point number)

= data point

Comments: Data Points $13 \& 14$ are the two points associated with Steps 1.8.3.25 \&

1.8.3.26. These are clearly seen to be at mid-range, as expected. The 95 reading for all other readings is the data logger reading the ambient signal on the Channel 3 input. This is acceptable and matches Figure 3 criteria. 
Revision 0

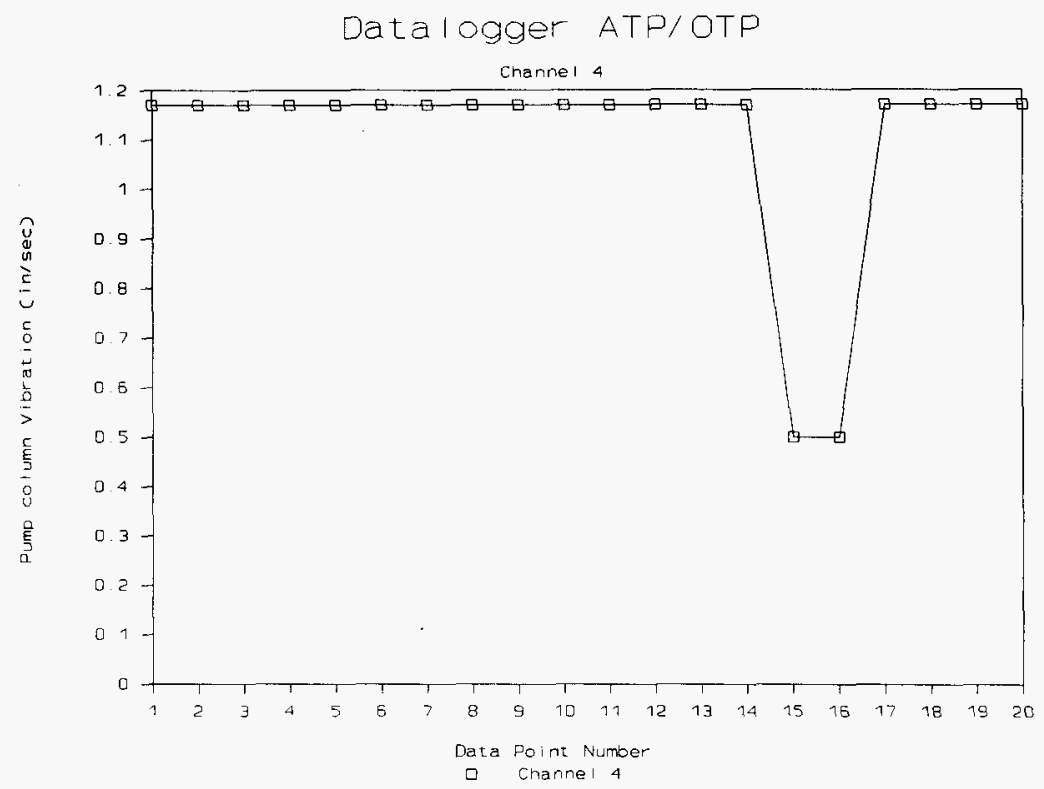

Graph 18: Channel 4 data collected during Section 1.8

Channel 4 is Pump Column Vibration

Vertical scale is inch/sec (Range is $0-1.0$ inch/sec)

Horizontal scale is time (data point number)

= data point

Comments: Data Points $15 \& 16$ are the two points associated with Steps $1.8 .3 .31 \&$ 1.8.3.32. These are clearly seen to be at mid-range, as expected. The 1.17 reading for all other readings is the data loggers reading the static signal on channel 4 . This is acceptable and matches figure 3 criteria. 
WHC-SD-WM-ATR-149

Revision 0

Data logger ATP/OTP

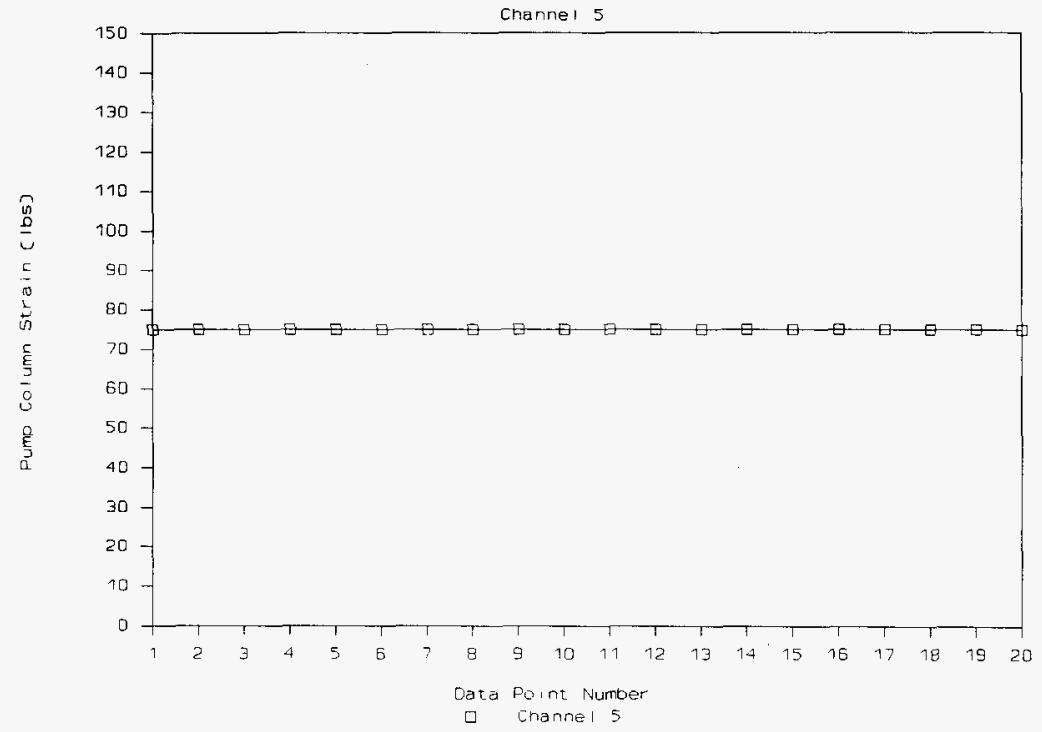

Graph 19: Channel 5 data collected during Section 1.8

Channel 5 is Pump Column Strain

Vertical scale is Pounds (Range is $0-150$ lbs)

Horizontal scale is time (data point number)

$=$ data point

Comments: Data Points $17 \& 18$ are the two points associated with Steps 1.8.3.38 \& 1.8.3.39. These are clearly seen to be at mid-range, as expected. Unfortunately the 75 pound reading for all other readings does not allow the conclusion that the data logger responded to the applied input. This is NOT acceptable and does not match Figure 3 criteria: see Test Exception \#10 and Graph 20 for data taken on retest. 
WHC-SD-WM-ATR-149

Revision 0

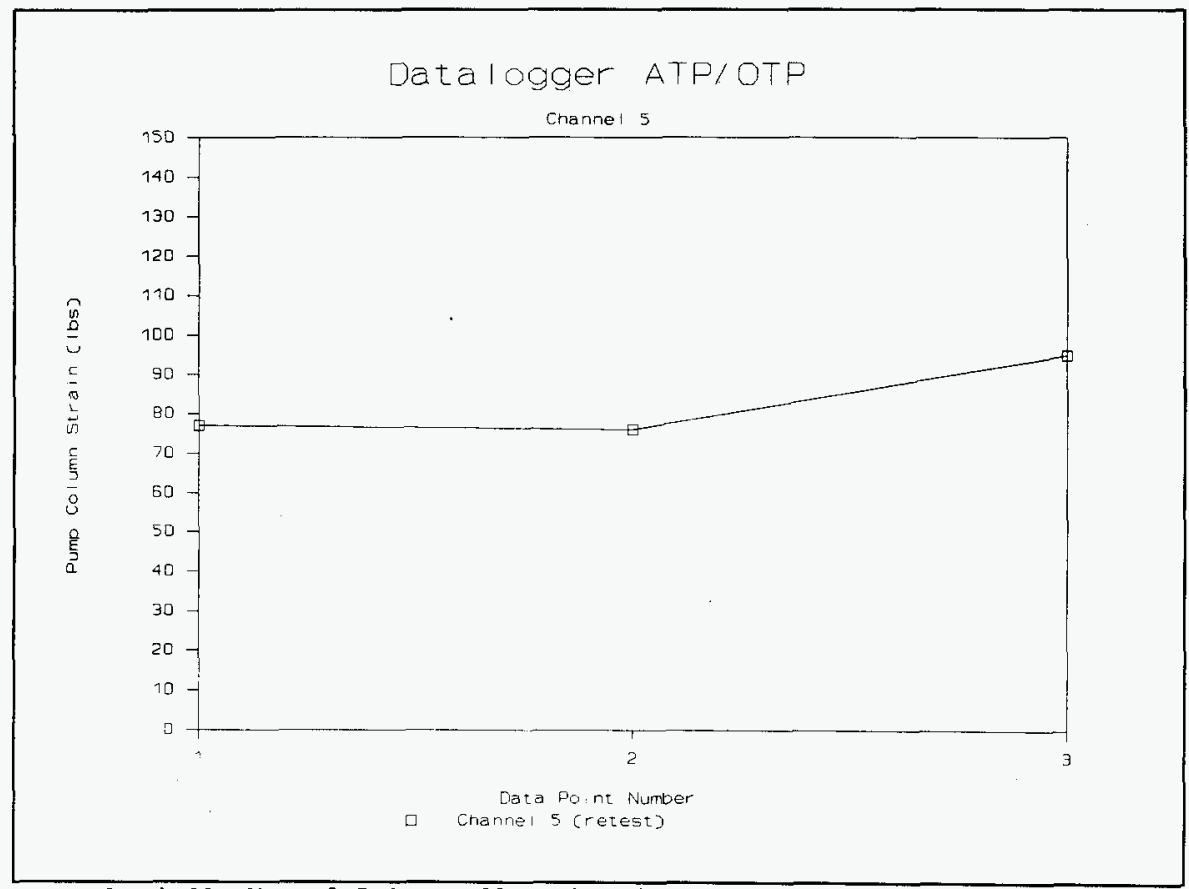

Graph 20: Channel 5 data collected during retest per Test Exception \#10

Channel 5 is Pump Column Strain

Vertical scale is Pounds (Range is $0-150$ lbs)

Horizontal scale is time (data point number)

$\square=$ data point

Comments: Data point \#1 is a spurious reading caused by noise while connecting the signal source to the data logger terminals. Data Points 2 \& 3 are the two points associated with Steps 1.8.3.38 \& 1.8.3.39. Data point \#2 is clearly seen to be at midzrange and the following data point is slightly higher, as expected. This is per the retest directions in Test Exception $\# 10$ and is acceptable. 


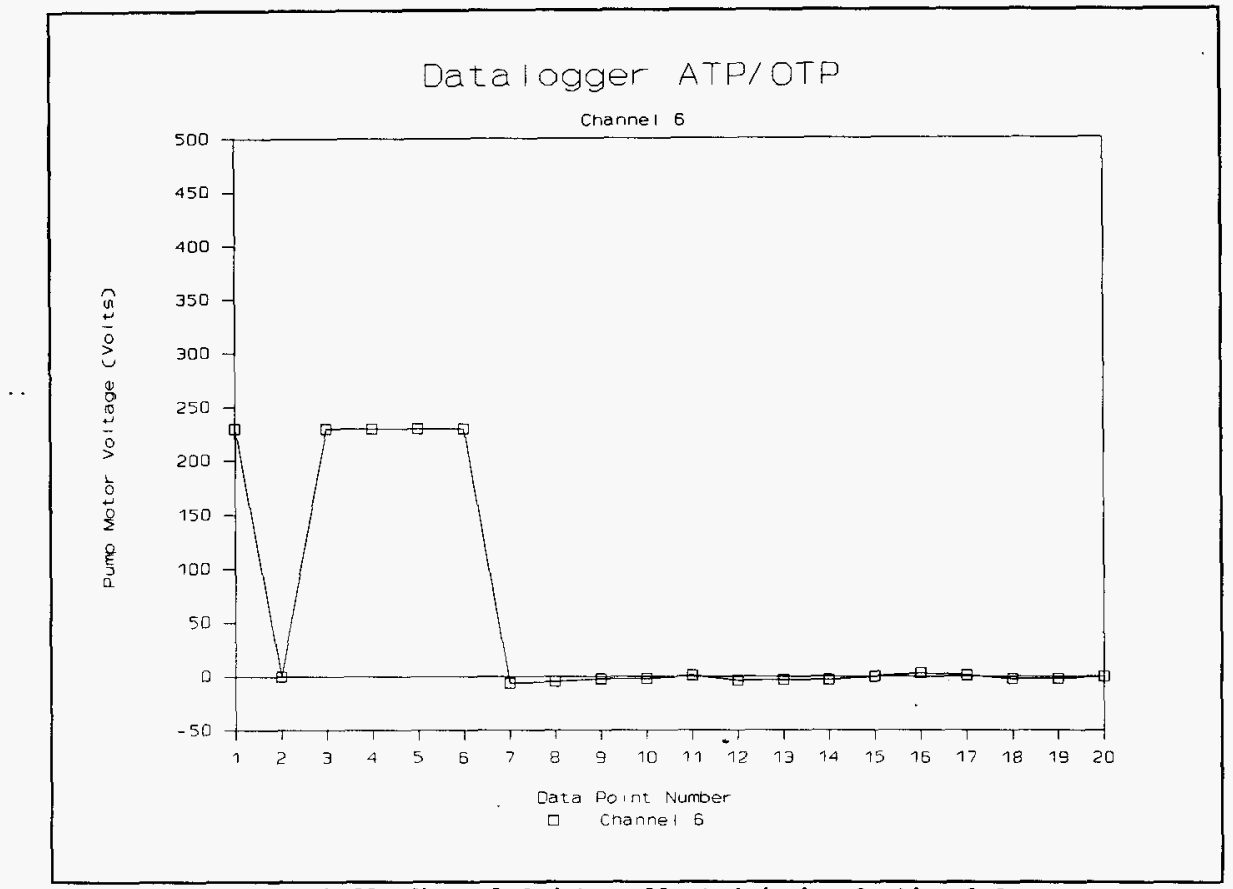

Graph 21: Channel 6 data collected during Section 1.8

Channel 6 is Motor Voltage

Vertical scale is Volts (Range is $0-460$ volts)

Horizontal scale is time (data point number)

$=$ data point

Comments: Data Points $5 \& 6$ are the two points associated with Steps 1.8.3.7 \& 1.8.3.8. These are clearly seen to be at mid-range, as expected. The near zero reading for all other readings (except $\# 1,3$, and 4 - spurious readings introduced by wires being connected/disconnected during the test procedure and efforts to determtne actual "trip point" of data logger) is the data loggers reading an "open circuit" on a voltage input. This is acceptable and matches Figure 3 criteria. 


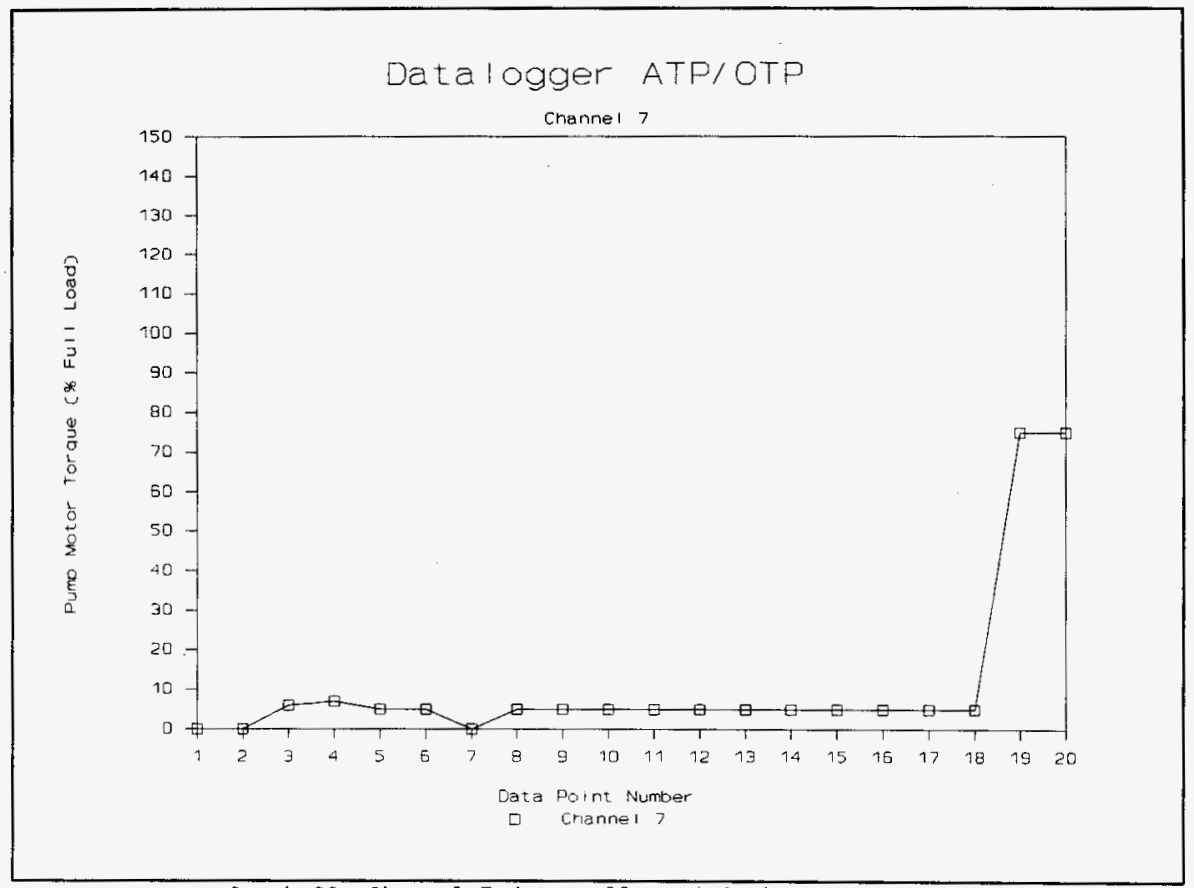

Graph 22: Channel 7 data collected during Section 1.8

Channel 7 is Motor Torque

Vertical scale is \% Full Load (Range is $0-150 \%$ )

Horizontal scale is time (data point number)

$=\operatorname{data}$ point

Comments: Data Points $19 \& 20$ are the two points associated with Steps $1.8 .3 .41 \&$ 1.8.3.42. These are clearly seen to be at mid-range, as expected. The near zero reading for all other readings is the data loggers attempt to read an "open circuit" on a voltage input. This is acceptable and matches Figure 3 criteria. 


\section{Listing 1: Datalogger Command file CA PUMP.CMD}

\section{RESET}

IW2

'PROGRAM FOR 241-AN-107

'CREATED BY NJ LEECH WHC SEPT 15,1995

' LAST MOD BY NJ LEECH WHC SEPT 20,1995

'THIS PROGRAM MONITORS MOTOR TORQUE (CH7) ONCE A SECOND (BY RZ)

' IF >.34V CH $1 . .7$ ARE LOGGED WITHIN 1 SEC (BY RX) AND THEN EVERY 5 MIN (BY RA)

'UNTIL CH7 <.32V, ALARM I LED IS ON WHILE LOGGING

'SET TIME TO PC, ADD DATE STAMP, UN SYNC TIME

$\mathrm{T}=\backslash \mathrm{t} \mathrm{D}=\backslash \mathrm{d} / \mathrm{T} / \mathrm{D} / \mathrm{s}$

'SET ALARM SCAN TO I SEC (RZ)

RZ1S

'DEFINE SPANS

$\mathrm{S} 1=0,90, .4,2 " \mathrm{KW"}$

$\mathrm{S} 2=0,1800, .4,2 " \mathrm{RPM} "$

$S 3=50,250, .4,2 " \operatorname{deg} F "$

$\mathrm{S} 4=0,1, .4,2^{\prime \prime}$ in $/ \mathrm{sec}^{\prime \prime}$

$S 5=0,150, .4,2 "$ "lbs"

$S 6=0,460,0,6^{\prime \prime}$ VAC"

$S 7=0,150,0,10 " \% "$

'SET TRIG FOR LOGGING AND DEFINE SCANS

'IFl $C H$ 7 $7>33 \mathrm{~V}$ LEDI IS TURNED ON, LOGGING IS STARTED, RX IS TRIGGERED,

'AND RA IS STARTED

'IF2 CH 7<.32V RA IS HALTED, LEDI IS TURNED OFF, LOGGING HALTED

IF1 (7HV>.34)" [LOGON $X$ GA]"

IF2(7HV<.32) "[HA LOGOFF]"

BEGIN

RX

IHV(S1,FFO," MOTOR POWER

2HV(S2,FFO," MOTOR RPM

3 HV (S3,FFO," MOTOR TEMP

4HV(S4,FF2," COLUMN VIBS

5HV (S5,FFO," COLUMN STRAIN ")

6HV(S6,FFO," MOTOR VOLTS ")

$7 H V(S 7, F F 0, "$ MOTOR TORQUE ")

RA5M

IHV(S1,FFO," MOTOR POWER

2HV(S2,FFO," MOTOR RPM

4 HV (S4,FF2," COLUMN VIBS ")

5HV(S5,FFO," COLUMN STRAIN ")

6HV(S6,FFO," MOTOR VOLTS ")

END

7HV(S7,FFO," MOTOR TORQUE ") 
WHC-SD-WM-ATR-149

Revision 0

Listing 2: File NORMDATA.PRN

\begin{tabular}{|c|}
\hline 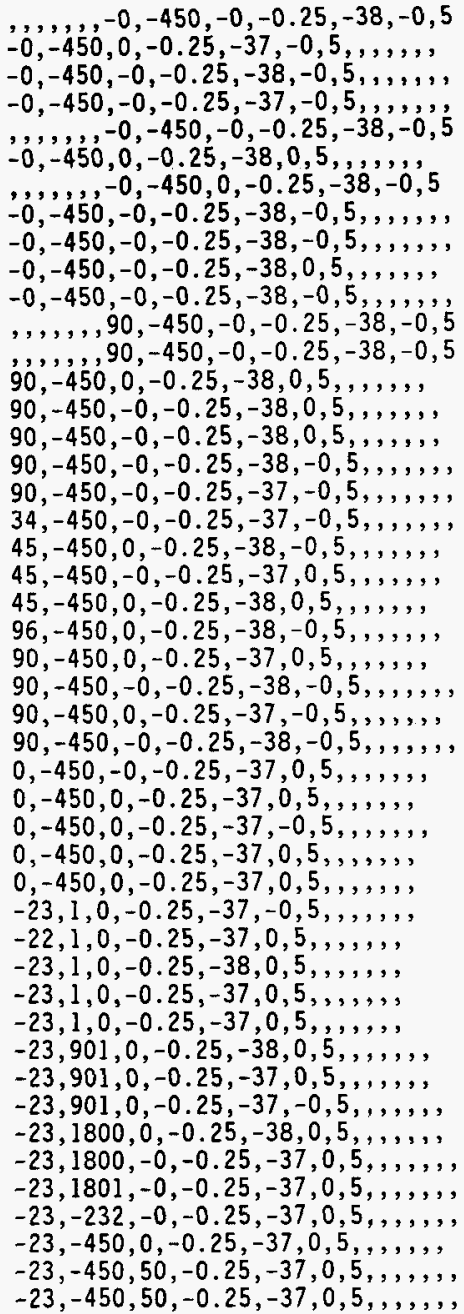 \\
\hline
\end{tabular}




\section{WHC-SD-WM-ATR-149}

Revision 0

\section{Listing 2 (Continued)}

$-22,-450,0,-0.25,-37,0,148,,,,,,$, ,

$-23,-450,-0,-0.25,-37,0,148,,,,,,,$, ,

$-22,-450,0,-0.25,-37,-0,148,,,,,,,$,

$-23,-450,0,-0.25,-37,0,148,,,,,,,$, ,

$-23,-450,0,-0.25,-37,0,149,,,,,,,$,

$-23,-450,0,-0.25,-37,0,118,,,,,,,$,

$-22,-450,0,-0.25,-37,0,3,,,,,,$, 


\section{WHC-SD-WM-ATR-149 \\ Revision 0}

$2458.43509,,,,,,,,,,-23,-451,-0,-0.25,-38,-0,8$

$2458.43513,-23,-451,-0,-0.25,-38,-0,8,,,,,,$, ,

$2458.43521,,, \ldots,,,,-23,-451,-0,-0.25,-38,-0,6$

$2458.43958,,,,,,,,-23,-450,-0,-0.25,-38,0,5$

$2458.43964,-23,-450,0,-0.25,-38,-0,5,,,,,,$, ,

$2458.43970,-23,-450,-0,-0.25,-37,-0,5,,,,,,$, ,

$2458.43976,-23,-450,-0,-0.25,-38,-0,5,,,,,,$, ,

$2458.43981,-23,-450,0,-0.25,-37,-0,5,,,,,,$, ,

$2458.43987,-23,-450,0,-0.25,-38,-0,5,,,,,,$, ,

$2458.43993,-23,-450,0,-0.25,-38,-0,5,,,,,,$, ,

$2458.43999,-0,-450,-0,-0.25,-38,-0,5,,,,,,$, ,

$2458.44005,-0,-450,-0,-0.25,-37,-0,5,,,,,,$, ,

$2458.44010,-0,-450,-0,-0.25,-37,0,5,,,,,,$, ,

$2458.44016,-0,-450,0,-0.25,-37,0,5,,,,,,$, ,

$2458.44022,45,-450,-0,-0.25,-38,0,5,,,,,,$, ,

$2458.44028,45,-450,0,-0.25,-37,0,5$,

$2458.44034,45,-450,0,-0.25,-37,0,5$,

$2458.44039,45,-450,0,-0.25,-37,0,5,,,$,

$2458.44039,45,-450,0,-0.25,-37,0,5,,,,,,$, ,

$2458.44045,90,-450,0,-0.25,-37,0,5,,,,,,$, ,

$2458.44051,90,-450,0,-0.25,-38,0,5,,,,,,$, ,

$2458.44057,90,-450,0,-0.25,-38,0,5,,,,$, , , ,

$2458.44063,-17,-450,0,-0.25,-37,0,5,,,,,,$, , ,

$2458.44068,-23,-450,0,-0.25,-37,0,5,,,,,,$, ,

$2458.44074,-22,-450,0,-0.25,-37,0,5,,,,,,$, ,

$2458.44080,-23,-450,0,-0.25,-37,0,5,,,,,$, ,

$2458.44086,-23,-450,0,-0.25,-37,0,5,,,,,$, , ,

$2458.44091,-23,-450,0,-0.25,-37,0,5,,,,,,$, ,

$2458.44097,-23,-450,0,-0.25,-37,0,5,,,,,,$, ,

$2458.44103,-22,-450,0,-0.25,-37,0,5,,,,,,$, ,

$2458.44109,-22,-450,0,-0.25,-37,0,5,,,,,,$, ,

$2458.44115,-22,-450,0,-0.25,-37,0,5,,,,,,$, ,

$2458.44120,-23,-451,-0,-0.25,-38,-0,5,,,,,,$, ,

$2458.44126,-23,-450,-0,-0.25,-38,-0,5,,,,,$, ,

$2458.44132,-23,-450,-0,-0.25,-38,-0,5,,,,,,$, ,

$2458.44138,-23,-450,-0,-0.25,-38,-0,5,,,,,,$, ,

$2458.44144,-23,-450,-0,-0.25,-38,-0,5,,,,,,$, ,

$2458.44149,-23,-450,-0,-0.25,-38,-0,5,,,,,,$, ,

$2458.44155,-23,-450,0,-0.25,-38,-0,5$,

$2458.44161,-23,-450,-0,-0.25,-38,-0,5,,,,,,$, ,

$2458.44167,-23,-451,-0,-0.25,-38,-0,5,,,,,,$, ,

$2458.44172,-23,-450,-0,-0.25,-38,-0,5,,,,,,$, ,

$2458.44178,-23,-450,0,-0.25,-38,0,5$,

$2458.44184,-23,-450,-0,-0.25,-38,-0,5$,

$2458.44184,-23,-450,-0,-0.25,-38,-0,5,,,,,,$, ,
$2458.44190,-23,-450,-0,-0.25,-38,-0,5,,,,,,$, ,

$2458.44196,-23,-450,-0,-0.25,-38,-0,5,,,,,,$, ,

$2458.44201,-23,-450,-0,-0.25,-38,-0,5,,,,,,$, ,

$2458.44207,-23,-450,-0,-0.25,-38,0,5$,

$2458.44213,-22,-450,-0,-0.25,-38,-0,5,,,,,$, ,

$2458.44219,-22,-450,-0,-0.25,-38,-0,5,,,,,,$, ,

$2458.44225,-23,-450,-0,-0.25,-38,-0,5,,,,,,$, , 


\section{Listing 3 (Continued)}

$2458.44520,-23,-450,-0,0.50,-38,-0,5,,,,,$, , $2458.44525,-23,-450,-0,0.50,-38,-0,5,,,,,,$, , $2458.44531,-23,-450,-0,1.00,-38,-0,5,,,,,,$, , $2458.44537,-23,-450,-0,1.00,-38,-0,5,,,,,,$, , $2458.44543,-23,-450,-0,1.00,-38,-0,5,,,,,,$, , $2458.44549,-23,-450,-0,-0.25,-38,-0,5,,,,,,$, , $2458.44554,-23,-450,-0,-0.25,-38,-0,5,,,,,,$, , $2458.44560,-23,-450,-0,-0.25,-38,-0,5,,,,,,$, , $2458.44566,-23,-450,-0,-0.25,-38,-0,5,,,,,,$, , $2458.44572,-23,-450,-0,-0.25,-38,-0,5,,,,,,$, , $2458.44578,-23,-450,-0,-0.25,-38,-0,5,,,,,,$, , $2458.44583,-23,-450,-0,-0.25,-38,-0,5,,,,,,$, , $2458.44589,-23,-450,-0,-0.25,-38,-0,5,,,,,,$, , $2458.44595,-23,-450,-0,-0.25,-38,-0,5,,,,,,$, , $2458.44601,-23,-450,-0,-0.25,-38,-0,5,,,,,,$, , $2458.44606,-23,-450,0,-0.25,-38,-0,5$, $2458.44612,-23,-450,-0,-0.25,-38,-0,5,,,,,$, , $2458.44618,-22,-450,-0,-0.25,-38,-0,5,,,,,,$, , $2458.44624,-23,-450,-0,-0.25,-38,-0,5,,,,,,$, , $2458.44630,-23,-450,-0,-0.25,-38,-0,5,,,,,,$, , $2458.44635,-23,-450,-0,-0.25,-38,0,5,,,,,$, , , $2458.44641,-23,-450,-0,-0.25,-38,-0,5,,,,,,,$, , $2458.44647,-23,-450,-0,-0.25,-38,-0,5,,,,,,$, , $2458.44653,-23,-450,-0,-0.25,-38,-0,5,,,,,$, , $2458.44659,-23,-450,-0,-0.25,-38,-0,5,,,,,,$, , $2458.44664,-23,-450,-0,-0.25,-38,-0,5,,,,,,$, , $2458.44670,-23,-450,-0,-0.25,-38,-0,5,,,,,,$, , $2458.44676,-23,-450,0,-0.25,-38,-0,5,,,,,,$, , $2458.44682,-23,-450,-0,-0.25,-38,-0,5,,,,,$, , , $2458.44688,-23,-450,-0,-0.25,-38,-0,5,,,,,,$, , $2458.44693,-23,-450,-0,-0.25,-38,-0,5,,,,,,$, , $2458.44699,-22,-450,0,-0.25,-38,0,5,,,,,,$, , $2458.44705,-23,-450,0,-0.25,-0,-0,5,, \ldots,,$, , $2458.44711,-22,-450,0,-0.25,-0,-0,5,,,,,,$, , $2458.44716,-23,-450,-0,-0.25,-0,-0,5,,,,,$, , , $2458.44722,-22,-450,0,-0.25,-0,-0,5$, $2458.44728,-22,-450,0,-0.25,75,0,5$, $2458.44734,-23,-450,0,-0.25,75,-0,5,,,,,$, , $2458.44740,-22,-450,-0,-0.25,75,-0,5,,,,,,$, , $2458.44745,-22,-450,-0,-0.25,158,0,5,,,,,,$, , $2458.44751,-23,-450,-0,-0.25,150,-0,5,,,,,,$, , $2458.44757,-22,-450,0,-0.25,150,-0,5,,,,,,$, , $2458.44763,-23,-450,-0,-0.25,150,-0,5,,,,,$, , , $2458.44769,-23,-451,-0,-0.25,150,-0,5,,,,,,$, , $2458.44774,-23,-450,-0,-0.25,-37,-0,5,,,,,,$, , $2458.44780,-23,-450,0,-0.25,-38,-0,5,,,,,,$, , $2458.44786,-23,-450,-0,-0.25,-38,-0,5,,,,,,$, , $2458.44792,-23,-450,-0,-0.25,-38,8,5,,,,,,$, , $2458.44797,-23,-450,0,-0.25,-38,8,5,, \ldots,,$, , $2458.44803,-23,-450,-0,-0.25,-38,8,5,,,,,,$, , 


\begin{abstract}
Listing 3 (Continued)
$2458.44809,-23,-451,-0,-0.25,-38,10,5,,,,,,$, , $2458.44815,-23,-450,-0,-0.25,-38,230,5,,,,,,$, , $2458.44821,-23,-450,-0,-0.25,-38,230,5,,,,,,$, , $2458.44826,-23,-450,-0,-0.25,-38,230,5,,$, , , , , , $2458.44832,-23,-450,-0,-0.25,-37,230,5,$, , , , , , $2458.44838,-23,-450,0,-0.25,-37,445,5,,,,,,$, , $2458.44844,-23,-451,-0,-0.25,-37,445,5,,,,,$, , , $2458.44850,-23,-450,-0,-0.25,-37,445,5,,,,,,$, , $2458.44855,-23,-450,-0,-0.25,-38,445,5,,,,,,$, , $2458.44861,-23,-450,-0,-0.25,-38,1,5,,,,,,$, , $2458.44867,-23,-450,-0,-0.25,-37,-0,5,,,,,,$, , $2458.44873,-23,-450,-0,-0.25,-38,0,5,,,,,,$, , $2458.44878,-23,-450,-0,-0.25,-37,0,35,,,,,,$, , $2458.44884,-23,-450,0,-0.25,-38,-0,75,,,,,,$, , $2458.44890,-23,-450,-0,-0.25,-38,-0,75,,,,,,$, , $2458.44896,-23,-450,0,-0.25,-38,0,75$, $2458,44902,-23,-450,-0,-0.25,-38,0,75, \cdots$, $2458.44907,-23,-450,-0,-0.25,-38,0,135,,,,,,$, , $2458.44913,-23,-450,-0,-0.25,-38,0,148,,,,,$, , , $2458.44919,-23,-450,0,-0.25,-38,0,148$, $2458.44925,-23,-450,0,-0.25,-38,0,148$, , $2458.44931,-23,-450,-0,-0.25,-37,0,148$, 2458.44936, $-23,-450,-0,-0.25,-37,0,148$, $2458.44942,-23,-450,0,-0.25,-38,-0,106,,,,,,$, , $2458.44948,-23,-450,-0,-0.25,-38,-0,5,,,,,,$, ,
\end{abstract}




\section{Listing 4: File CAM_DAT.PRN (annotated: data in Lotus 1-2-3 format)}

Time/date Channel 1-7 data

2496.46652,,, , , , , $-23,-451,95,1.17,75,230,-0$
$2496.47498,,,,,,,,,-23,-451,94,1.17,75,-0,-0$ $2496.47723,,,,,,,-23,-451,94,1.17,75,230,6$ $2496.47942,,,,,,,,,,-23,-450,94,1.17,75,230,7$ $2496.47972,,,,,,,,-23,-451,94,1.17,75,230,5$ $2496.48319,-23,-451,94,1.17,75,230,5,,,,,,$, , $2496.54443,,,,,,,,,-23,-451,94,1.17,75,-6,-0$ $2496.54707,,,,,,,, 43,-450,94,1.17,75,-5,5$ $2496.55054,43,-451,94,1.17,75,-2,5,,,,,,$, , $2496.55091,,,,,,,, 39,-450,94,1.17,75,-2,5$ 2496.55459, , , , , , , , $-23,864,94,1.17,75,1,5$ $2496.55807,-23,858,94,1.17,75,-4,5,,,,,,$, , $2496.57380,,,,,,,,,-23,-451,150,1.17,75,-3,5$ $2496.57727,-23,-451,150,1.17,75,-3,5,,,,,$, , $2496.58229,,,,,,,,,-23,-451,94,0.50,75,-0,5$ $2496.58576,-23,-451,94,0.50,75,3,5,,,,,$,

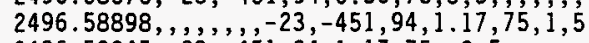
$2496.59245,-23,-451,94,1.17,75,-2,5,,,,,$, , , 2496.59373, , , , , , , -23, -451,94,1.17,75, ', ', , 75 $2496.59720,-22,-450,94,1.17,75,-0,75,,,,,,$, ,
Step No.

Spurious

Spurious

Spurious

Spurious

Step 1.8.3.7

Step 1.8.3.8

Spurious

Step 1.8.3.13

Step 1.8.3.14

Spurious

Step 1.8.3.19

Step 1.8.3.20

Step 1.8.3.25

Step 1.8.3.26

Step 1.8.3.31

Step 1.8.3.32

Step 1.8.3.38

Step 1.8.3.39

Step 1.8.3.41

Step 1.8.3.42
Comment

Note 1

Note 2

Note 2

Note 2

Channel 6

Note 1

Channel 1

Note 1

Channel 2

Channel 3

Channe1 4

Channel 5

Channel 7

Note 1: Spurious trip caused by wires being connected/disconnected during the test procedure.

Note 2: Spurious trip caused by efforts to determine datalogger "trip point". It was determined that the datalogger would NOT "trip" [and record the data] at 0.33 volts, but would respond at 0.34 volts which is within the tolerance specified in the procedure [0.33 $(-0.00,+0.02)$ volts $]$. 


\section{WHC-SD-WM-ATR-149 \\ Revision 0}

Listing 5: File CAM_RT.PRN (annotated: data in Lotus 1-2-3 format)

Time/date Channel 1-7 data

$2507.58913,,,,,,,,-23,-450,94,1.17,77,20,0$

$2507.58928,,,,,,,,,,-23,-450,93,1.17,76,15,5$

$2507.59275,-23,-450,94,1.17,95,8,5,,,,,,$, ,
Step No.

Spurious

Step 1.8.3.38

Step 1.8.3.39
Comment

Note 1

Channel 5

Note 1: Spurious trip caused by wires being connected/disconnected during the test procedure. 
WHC-SD-WM-ATR-149

Revision 0

APPENDIX B - TEST EXCEPTIONS

B-1 
WHC-SD-WM-ATR-149

Revision $O$

TEST EXCEPTION \# 1

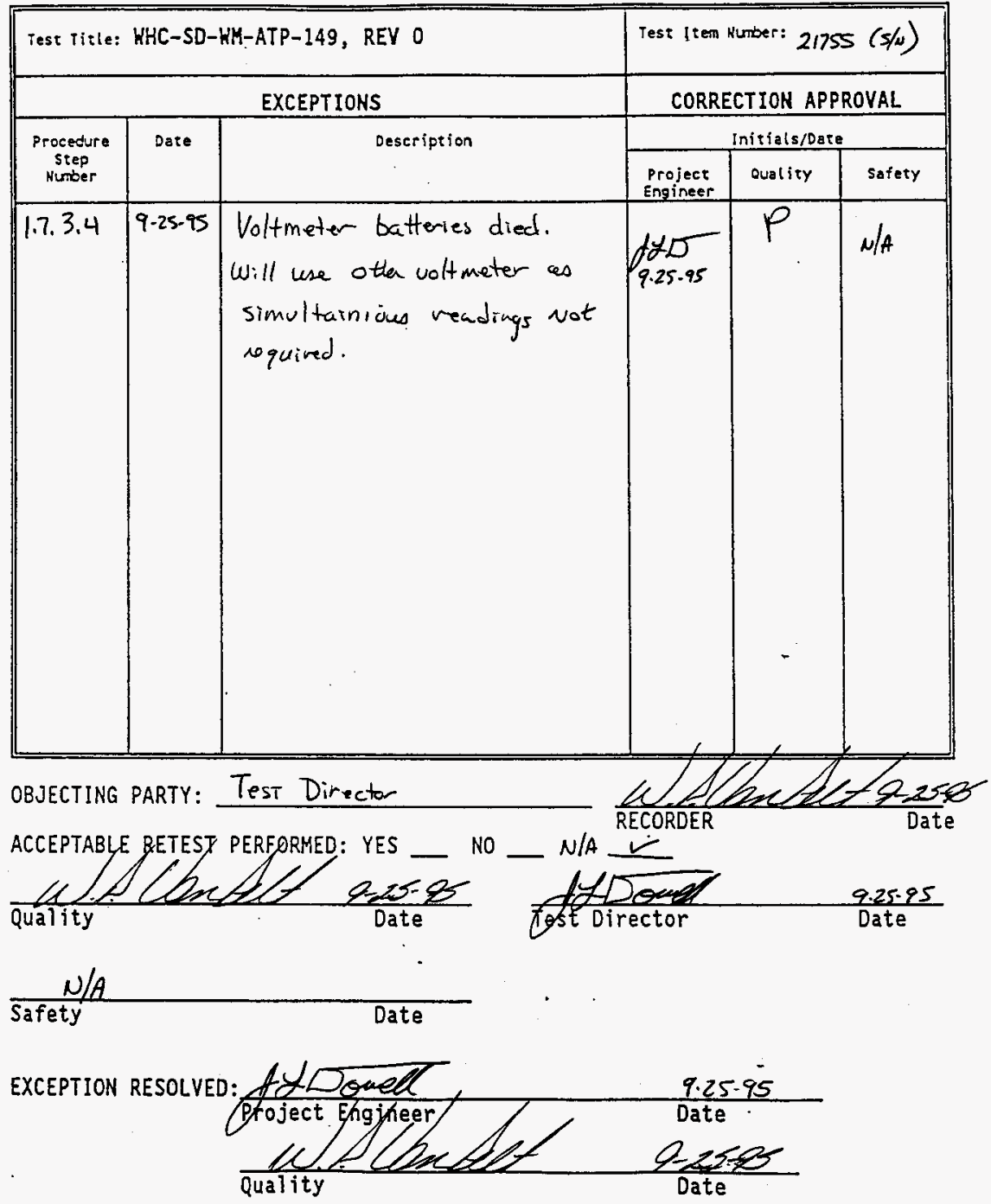


WHC-SD-WM-ATR-149

Revision 0

TEST EXCEPTION * 2

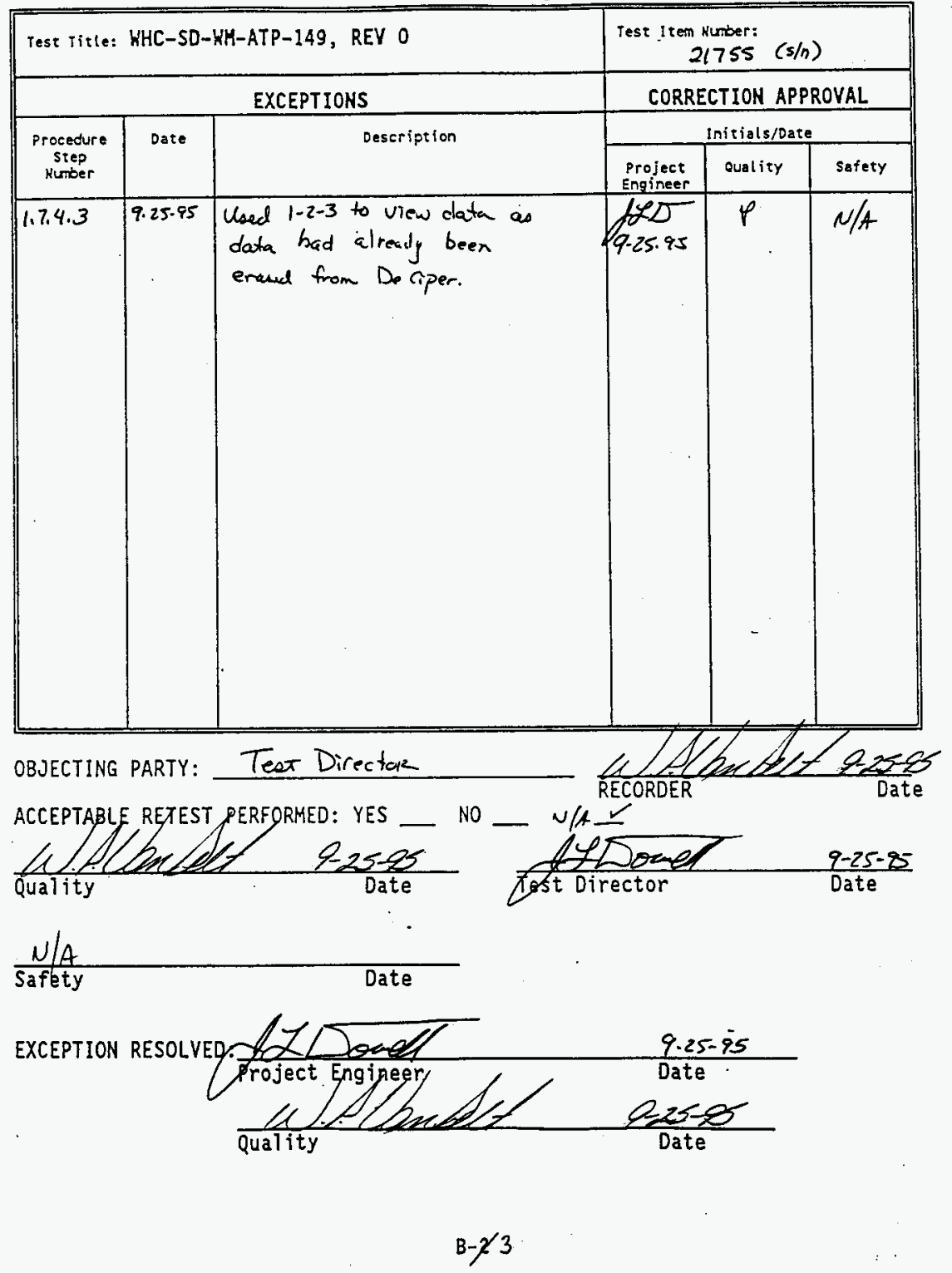


WHC-SD-WM-ATR-149

Revision 0

TEST EXCEPTION \# 3

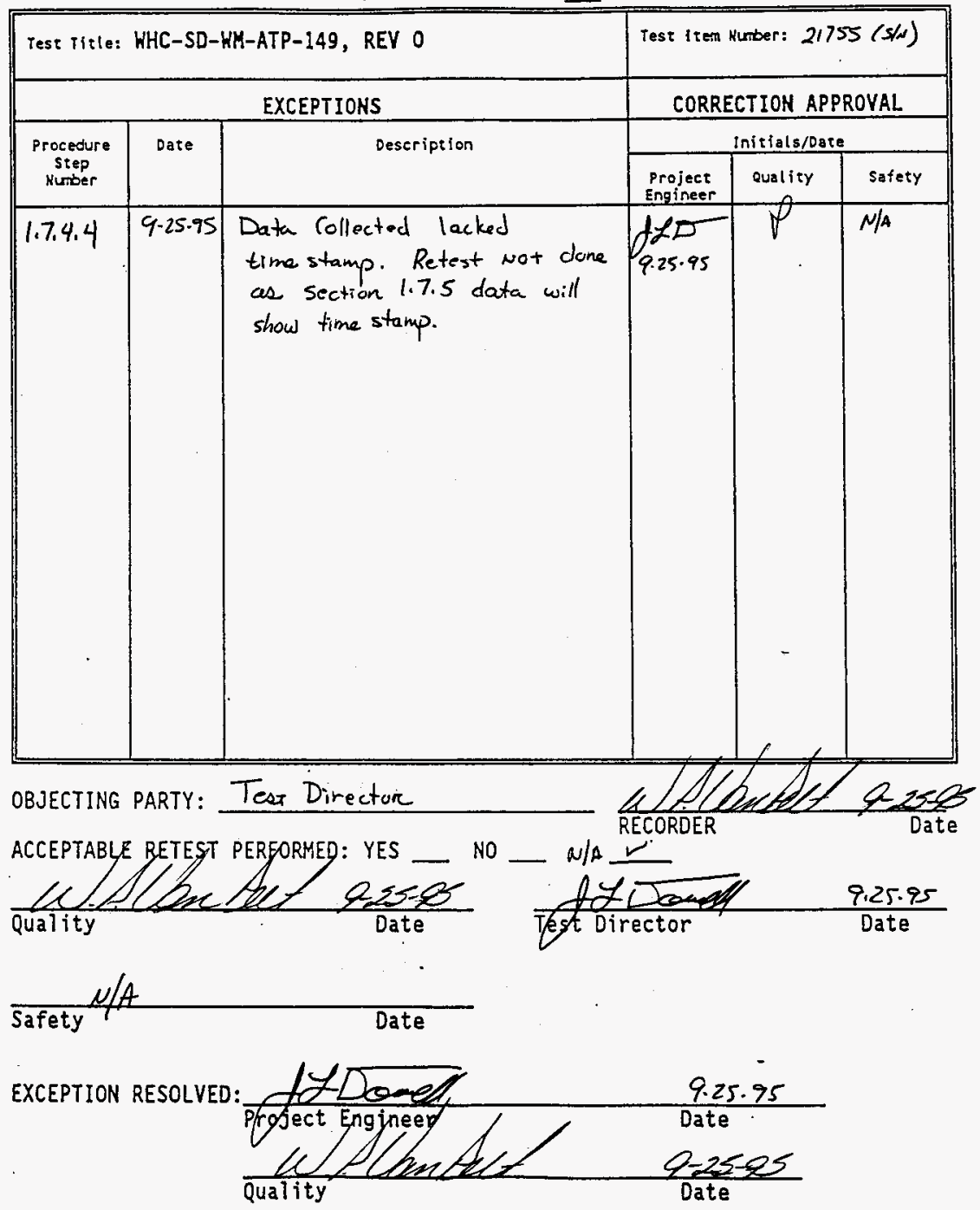


WHC-SD-WM-ATR-149

Revision 0

TEST EXCEPTION \# 4

\begin{tabular}{|c|c|c|c|c|c|}
\hline \multicolumn{3}{|c|}{ rest ritle: WHC-SO-KM-ATP-149, REY O } & \multicolumn{3}{|c|}{$\begin{array}{l}\text { Test 1ten Nunber: } \\
21755(s / h)\end{array}$} \\
\hline \multicolumn{3}{|r|}{ EXCEPTIONS } & \multicolumn{3}{|c|}{ CORRECTION APPROVAL } \\
\hline \multirow{2}{*}{$\begin{array}{l}\text { Procecture } \\
\text { step } \\
\text { Nunber }\end{array}$} & \multirow[t]{2}{*}{ Date } & \multirow[t]{2}{*}{ Deseription } & \multicolumn{3}{|c|}{ initials/Date } \\
\hline & & & $\begin{array}{l}\text { Projeet } \\
\text { Engineer }\end{array}$ & Quality & Safety \\
\hline 1.7 .5 .7 & $9-25.95$ & $\begin{array}{l}\text { Test Data shat lacts } \\
\text { spot to recond data. Added } \\
\text { tie to test date sheet. }\end{array}$ & $\begin{array}{l}1+P_{95} \\
2.25 \cdot .20\end{array}$ & $P_{0 / 25 / 25}$ & $N / A$ \\
\hline
\end{tabular}

OBJECTING PARTY: Reconder

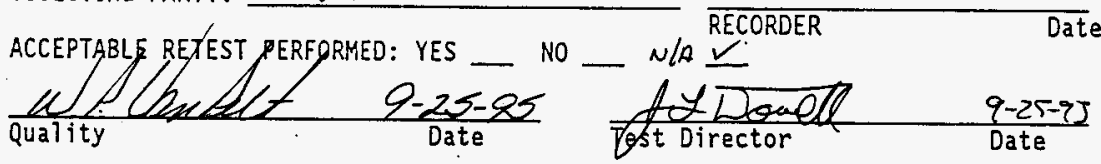

\begin{tabular}{ll} 
Safety & \\
\hline
\end{tabular}

EXCEPTION RESOLVED: $\frac{4}{\text { Project Enginer }}$ 
WHC-SD-WM-ATR-149

Revision $O$

TEST EXCEPTION \# 5

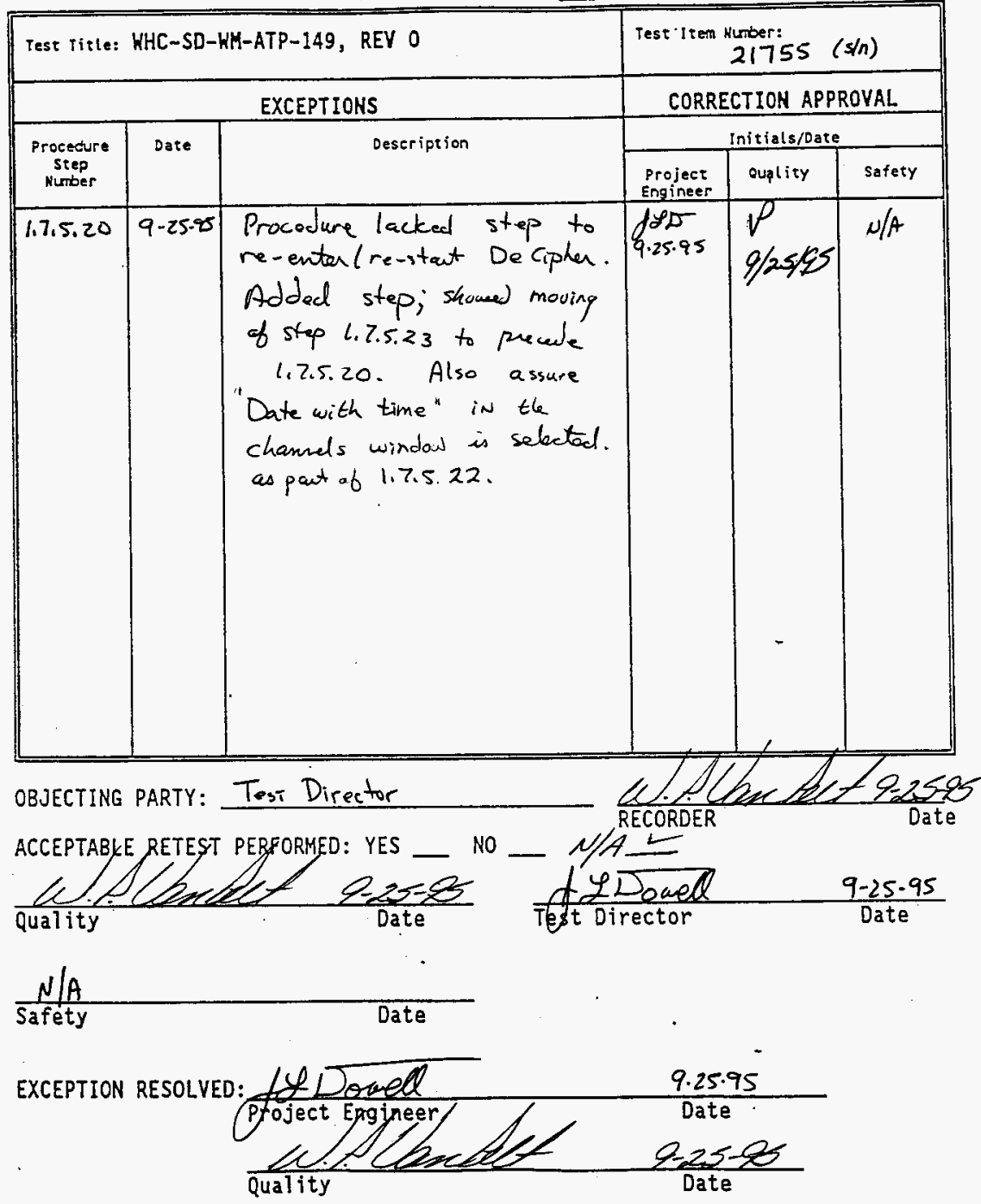


WHC-SD-WM-ATR-149

Revision 0

TEST EXCEPTION \# 6

\begin{tabular}{|c|c|c|c|c|c|}
\hline \multicolumn{3}{|c|}{ rest ritle: WHC-SD-WM-ATP-149, REV 0} & \multicolumn{3}{|c|}{ Test Item Number: 21755} \\
\hline \multicolumn{3}{|r|}{ EXCEPTIONS } & \multicolumn{3}{|c|}{ CORRECTION APPROVAL } \\
\hline \multirow{2}{*}{$\begin{array}{c}\text { Procedure } \\
\text { Step } \\
\text { Number }\end{array}$} & \multirow[t]{2}{*}{ Date } & \multirow{2}{*}{ Deseription } & \multicolumn{3}{|c|}{ Initials/oate } \\
\hline & & & $\begin{array}{l}\text { Project } \\
\text { Engineer }\end{array}$ & Quality & Safety \\
\hline $1.8 \% .7$ & 11.2 .95 & 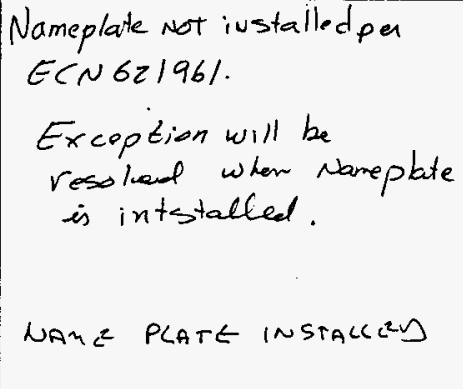 & $\frac{780}{11.2 .95}$ & $\begin{array}{l}K / 21 / 2 / 95 \\
K \omega \\
11 / 15 / 95\end{array}$ & $\begin{array}{c}- \\
N / A\end{array}$ \\
\hline
\end{tabular}

OBJECTING PARTY: Test Director QCCEPTABLE RETEST PERFORMED: YES $N / A$

Safety Date

EXCEPTION RESOLVED.
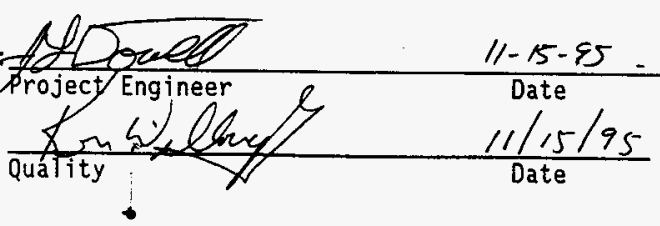
WHC-SD-WM-ATR-149

Revision $O$

TEST EXCEPTION \# 7

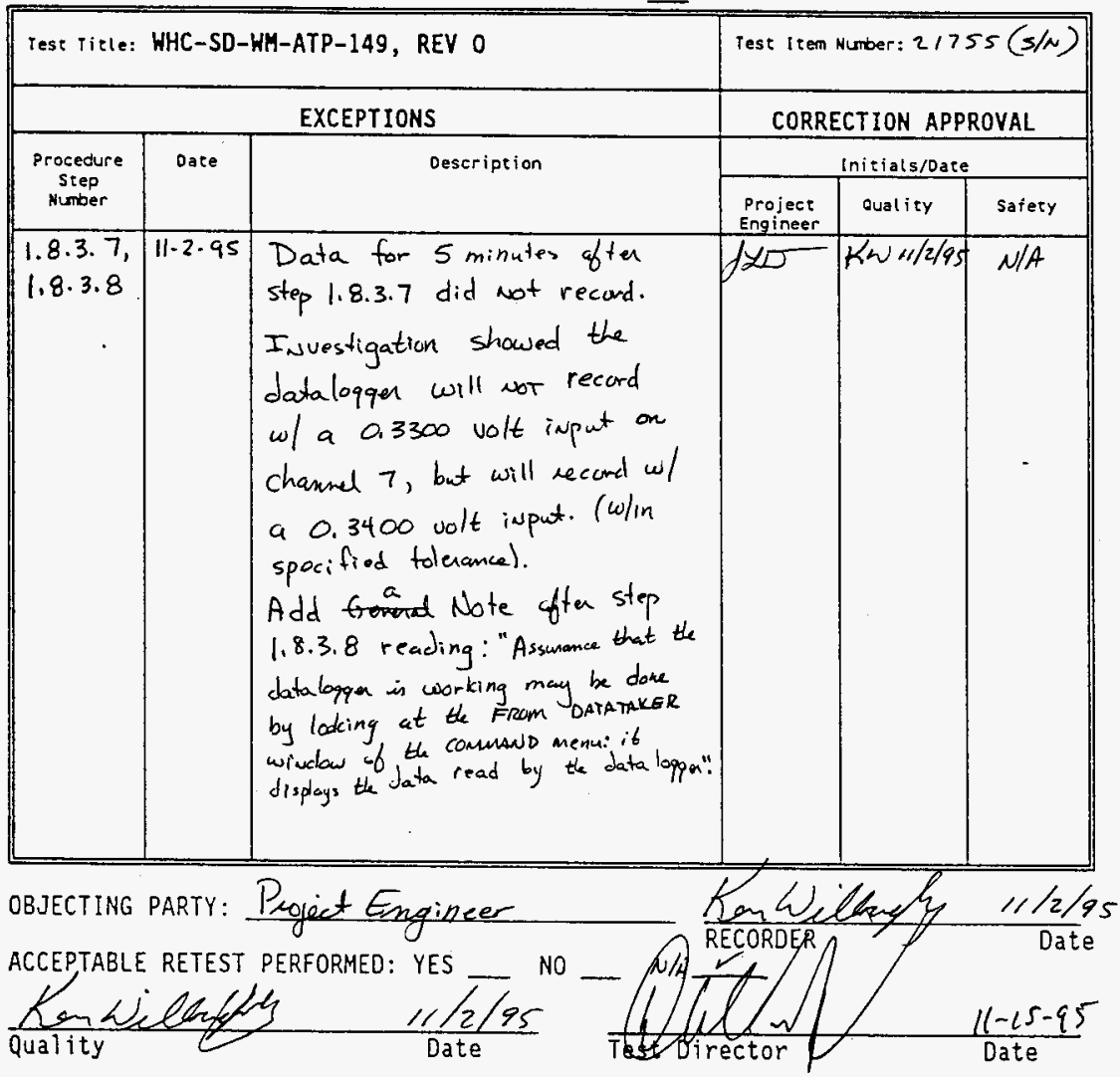

$\frac{N / A}{\text { Safety }}$

Date

exception resolved fl boud

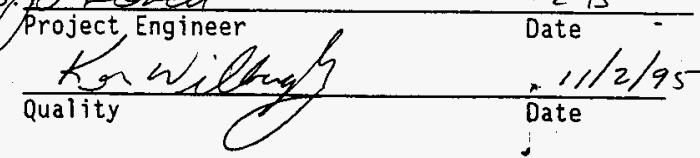


WHC-SD-W'M-ATR-149

Revision 0

TEST EXCEPTION \# 8

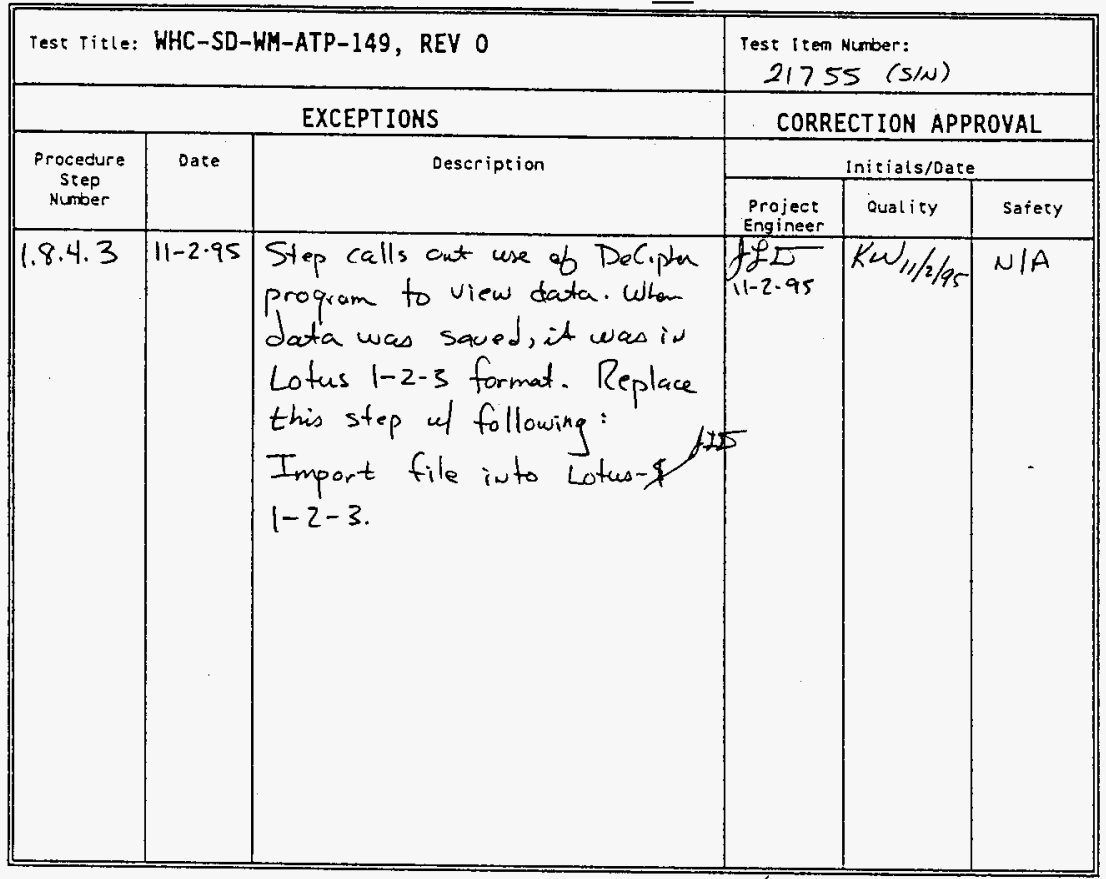

Objecting party: Project Engineer $\frac{\text { Non willing } / 1 / 2 / 95}{\text { RECORDER }}$ ACCEPTABLE RETEST PERFORMED: YES

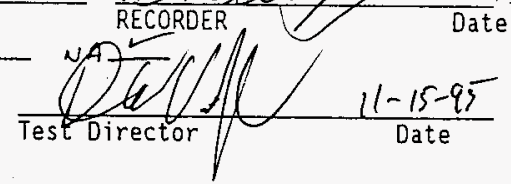
$\frac{\text { Non willy } \frac{11 / 2 / 95}{\text { Quality }}}{\text { Ken wiccoughi }}$ $6 / 4$ Safety Date

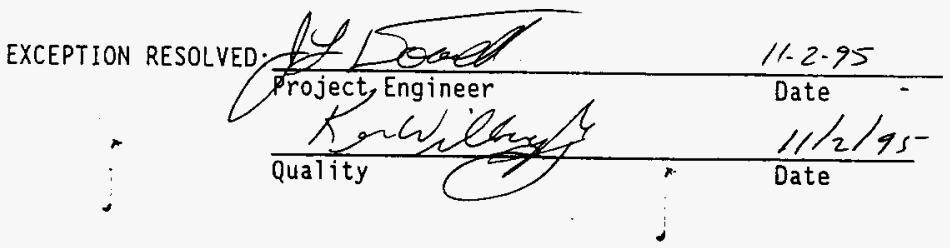

$B-29$ 
WHC-SD-WM-ATR-149

Revision 0

TEST EXCEPTION \# 9

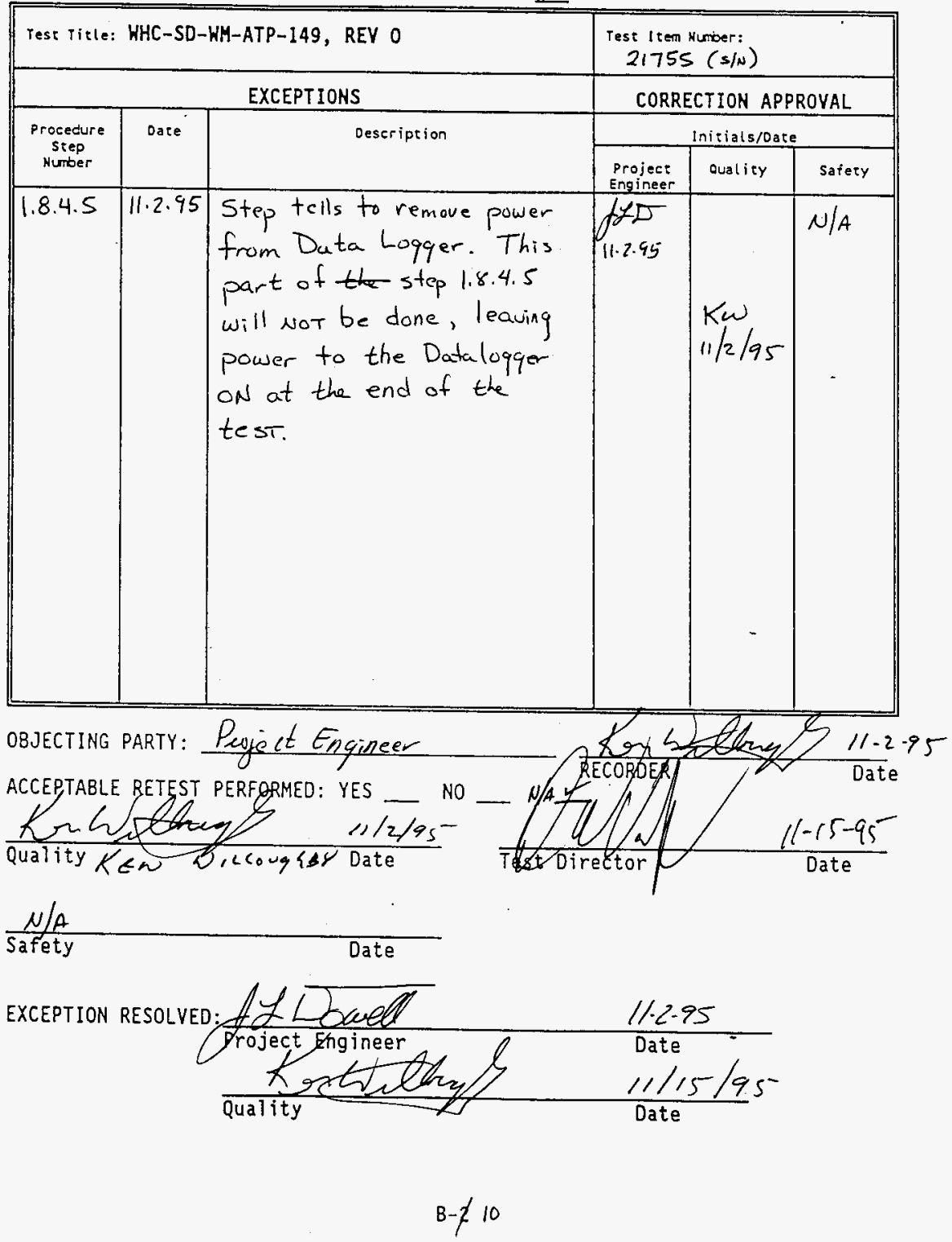


WHC-SD-WM-ATR-149

Revision 0

TEST EXCEPTION \#10

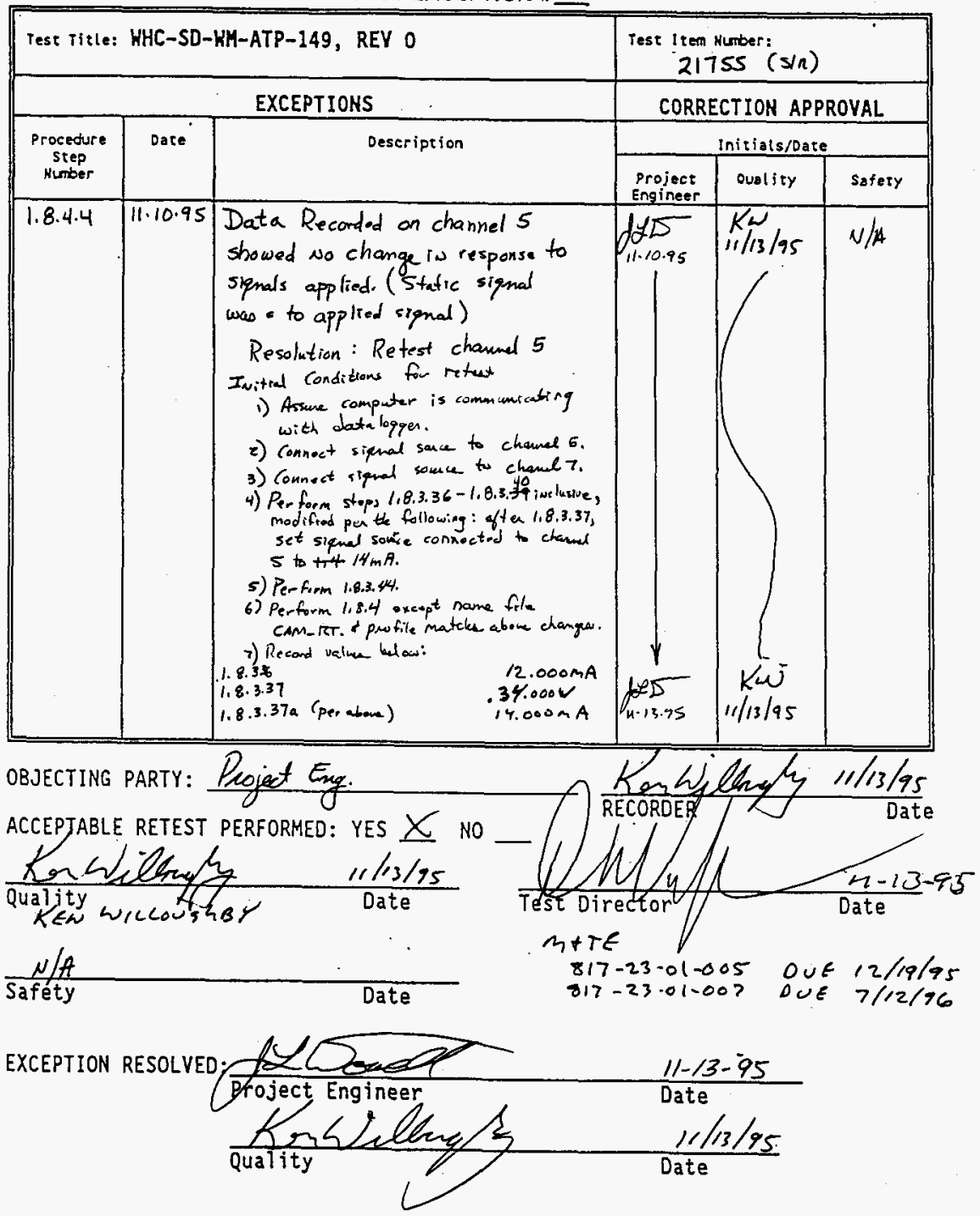


WHC-SD-WM-ATR-149

Revision 0

\section{APPENDIX C - TEST LOG SHEET}

(Copy as needed) 


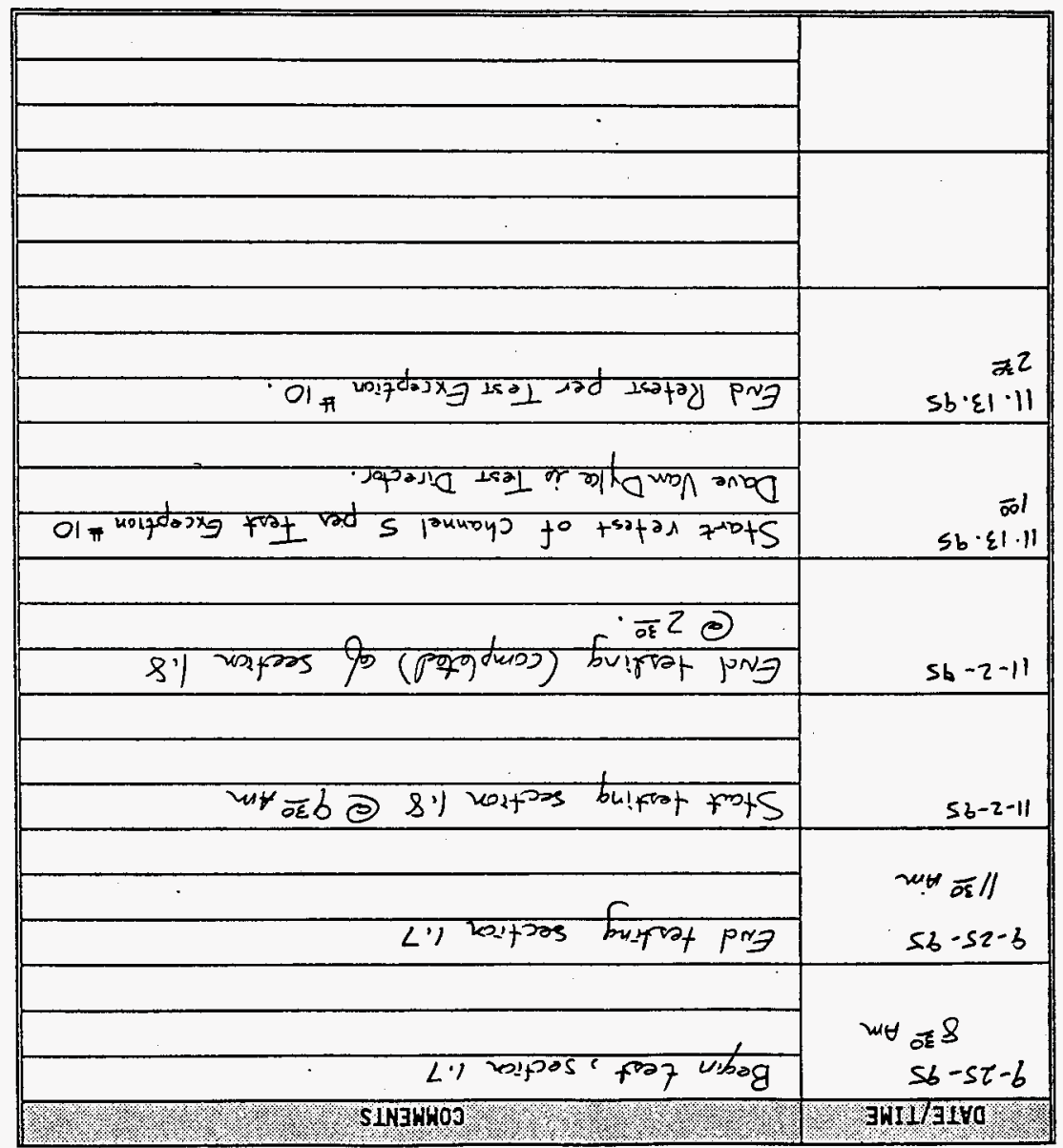

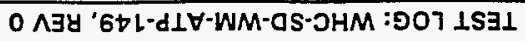


WHC-SD-WM-ATR-149

Revision $O$

APPENDIX D - TEST EXECUTION SHEET 
WHC-SD-WM-ATR-149

Revision 0

TEST EXECUTION SHEET: PRE-INSTALLATION

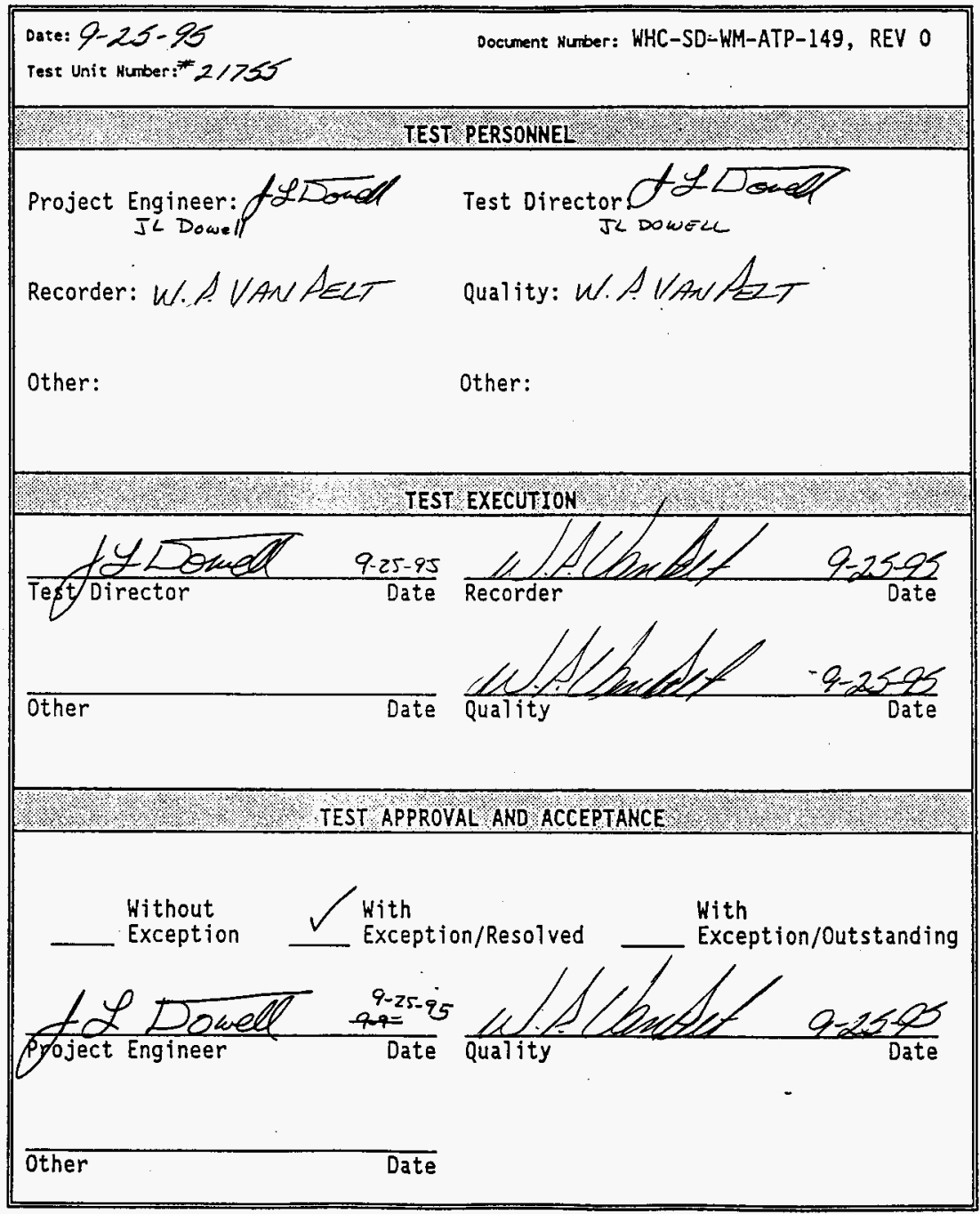


TEST EXECUTION SHEET: POST-INSTALLATION

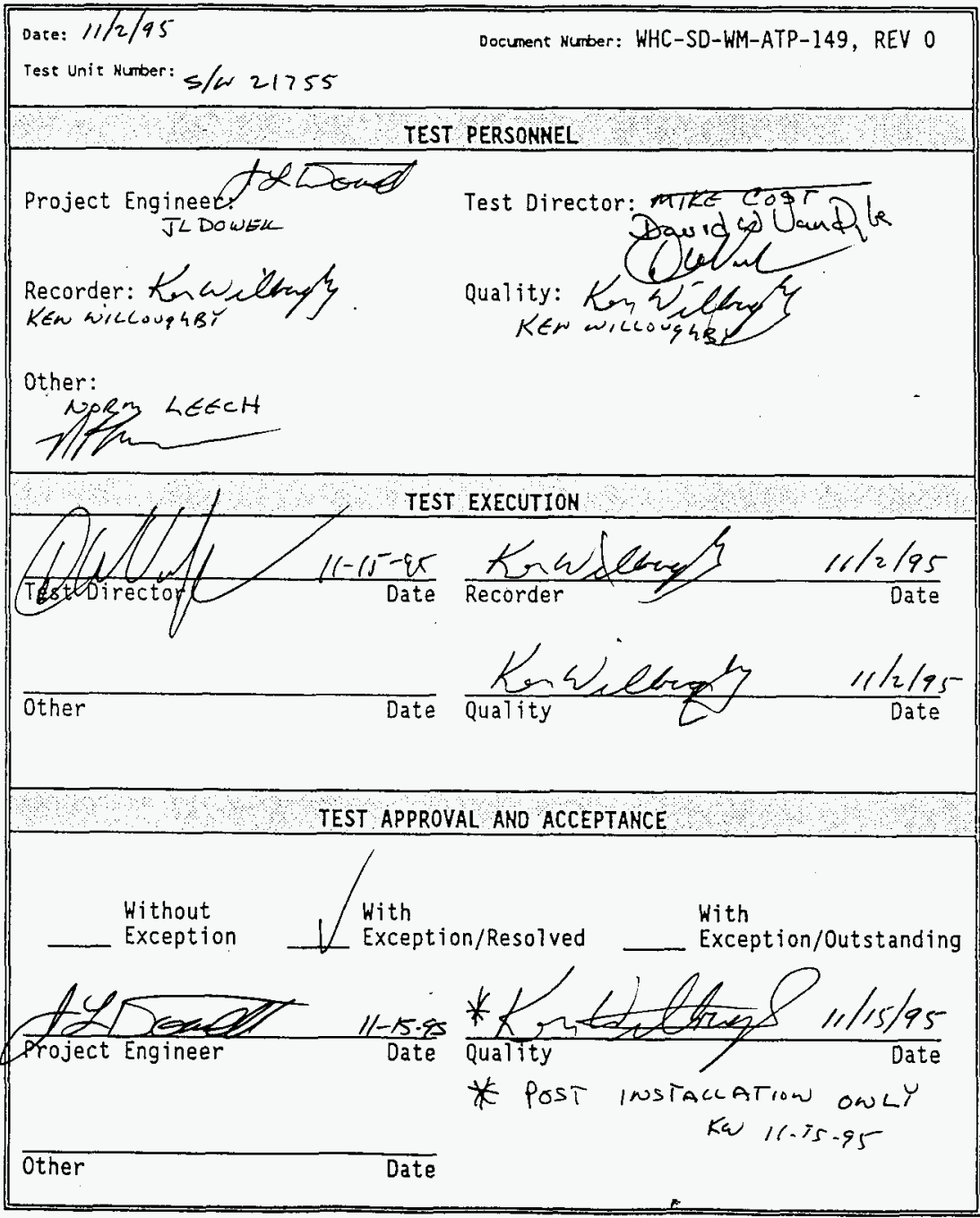




\section{WHC-SD-WM-ATR-149 \\ Revision 0}

APPENDIX E - DeCipher/DeTerminal SCREENS 


\section{WHC-SD-WM-ATR-149 \\ Revision 0}

Connect Command Data File Plot Meter Run Setup ? C2 $\uparrow$ 09:10:10

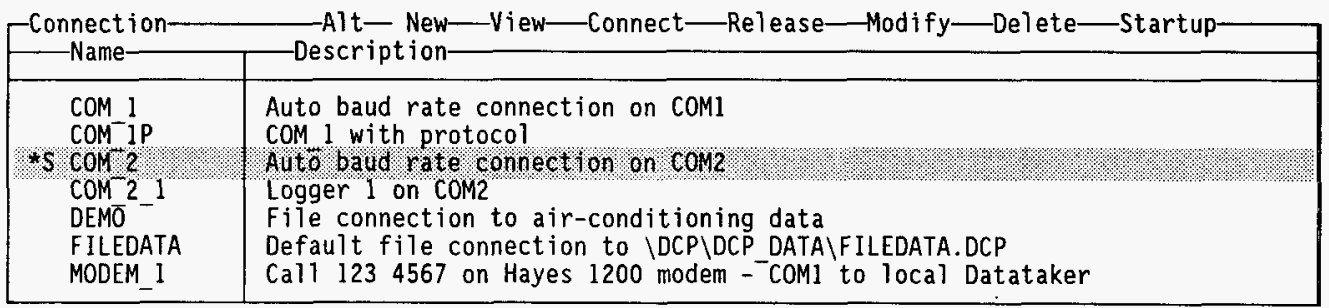


WHC-SD-WM-ATR-149

Revision 0

Connect Commano Data File Plot Meter Run Setup ? C2 $\uparrow$ 09:10:10

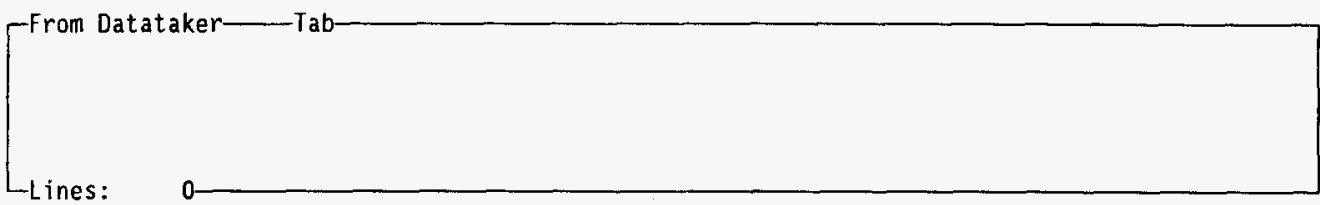

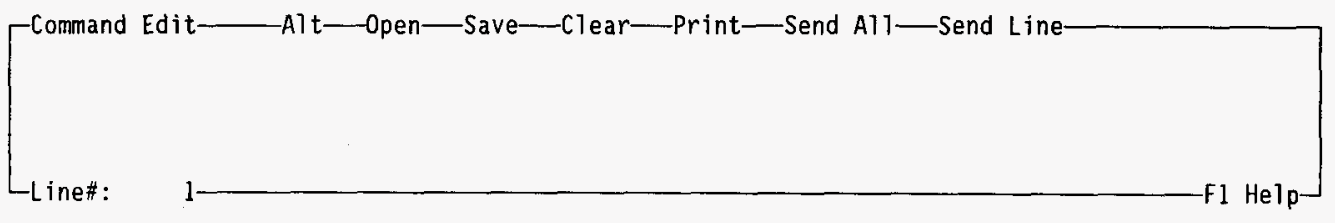

Connected to COM_2

$6 \quad 12688$ 
Connect Command Data File Plot Meter Run Setup ? C2 $\uparrow$ 09:10:10

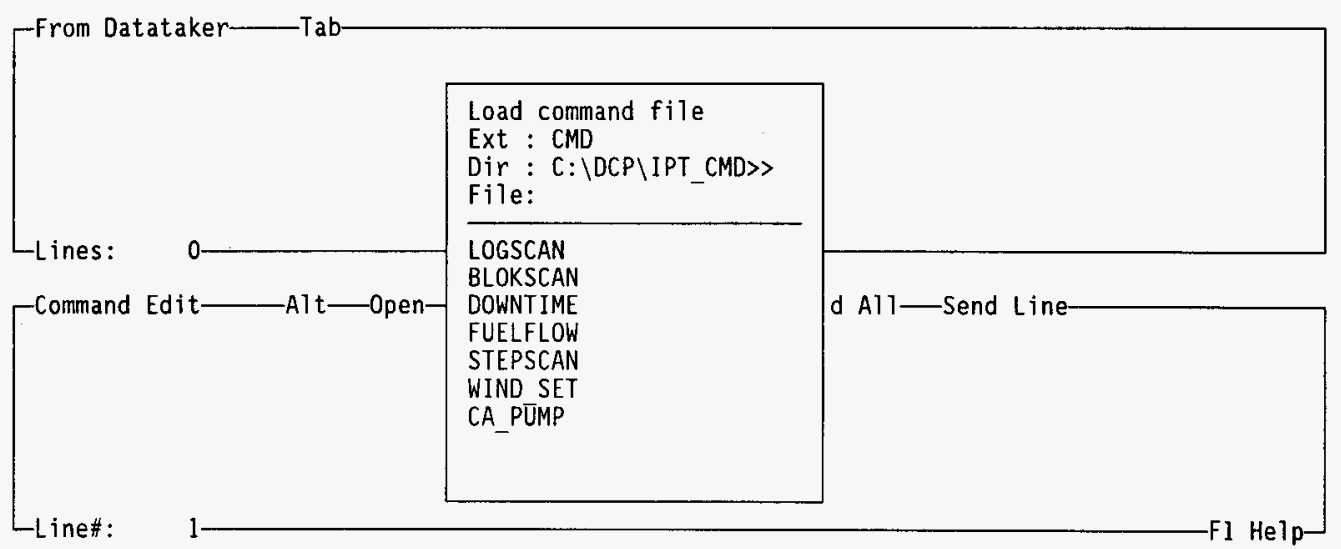

Connected to COM_2 
WHC-SD-WM-ATR-149

Revision 0

Connect Command fata File Plot Meter Run Setup ? C2 $\uparrow$ 09:10:10 Source- Alt-Task RealTime Logged then Stop Logged then Continue

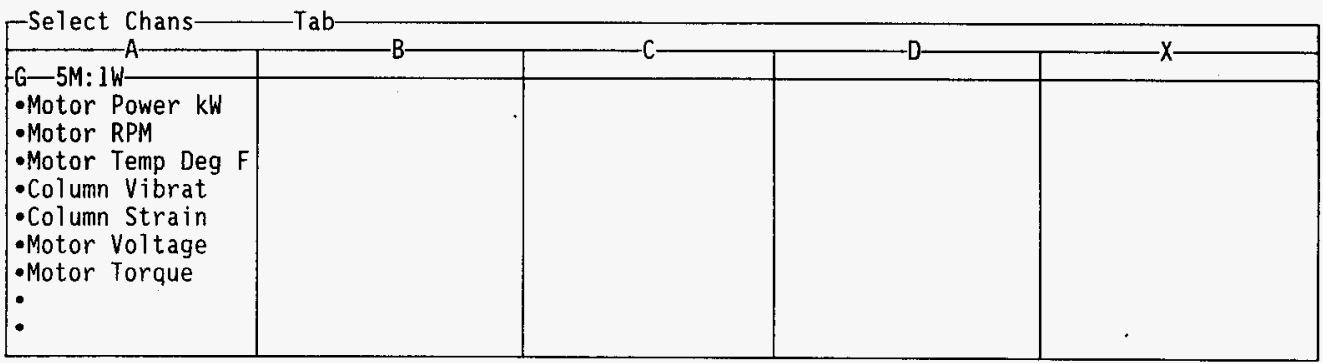

-DescriptionTitle [ Tab- 
WHC-SD-WM-ATR-149

Revision 0

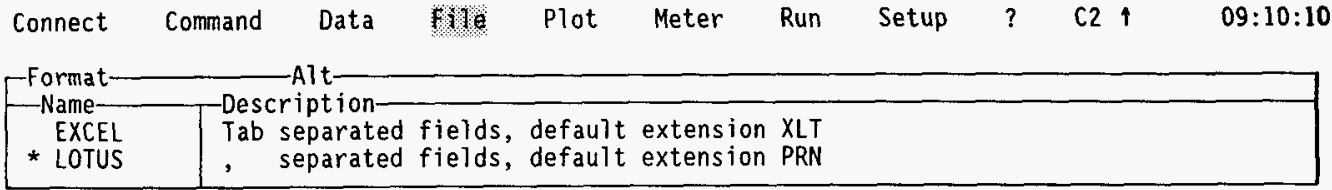

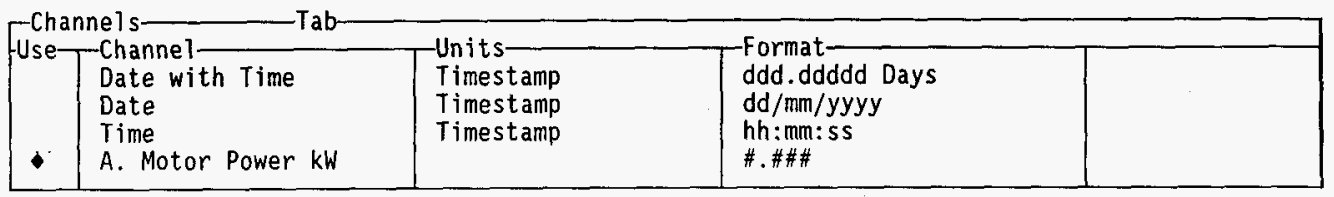

\begin{tabular}{|cc|} 
Send To & Tab \\
\hline File & No Yes \\
Printer & No Yes \\
Screen & No Yes \\
\hline
\end{tabular}

Connected to $\mathrm{COM}_{2} 2$

0 13958 


\section{WHC-SD-WM-ATR-149 \\ Revision 0}

\begin{tabular}{|c|c|c|c|c|c|c|c|c|c|c|}
\hline Connect & Command & Data & fole & Plot & Meter & Run & Setup & $?$ & $\mathrm{C} 2 \uparrow$ & $09: 10: 1$ \\
\hline $\begin{array}{l}\text {-Format- } \\
\text {-Name- }\end{array}$ & -Des & & & & & & & & & \\
\hline $\begin{array}{l}* \text { LOTUS } \\
\text { QUATTRO }\end{array}$ & & $\begin{array}{l}\text { separate } \\
\text { separate }\end{array}$ & $\begin{array}{l}\text { fields, } \\
\text { fields, }\end{array}$ & $\begin{array}{l}\text { defaul } \\
\text { defaul }\end{array}$ & $\begin{array}{l}\text { extensi } \\
\text { extensi }\end{array}$ & $\begin{array}{l}\text { PRN } \\
\text { QTR }\end{array}$ & & & & \\
\hline
\end{tabular}

\begin{tabular}{|c|c|c|c|}
\hline Use & -Channel- & -Units- & -Format- \\
\hline$\bullet$ & $\begin{array}{l}\text { Date with Time } \\
\text { Date } \\
\text { Time } \\
\text { A. Motor Power kW }\end{array}$ & $\begin{array}{l}\text { Timestamp } \\
\text { Times tamp } \\
\text { Timestamp }\end{array}$ & $\begin{array}{l}\text { ddd.ddddd Days } \\
\text { dd/mm/yyyy } \\
\text { hh:mm:ss } \\
\# . \# \# \#\end{array}$ \\
\hline
\end{tabular}

\begin{tabular}{ccc|} 
Send To- Alt_-Printer Setup- & No Yes & \\
File & NoBMDATA \\
Name & No Yes \\
Printer & No Yes \\
Screen & No Yes
\end{tabular}




\section{WHC-SD-WM-ATR-149}

Revision 0

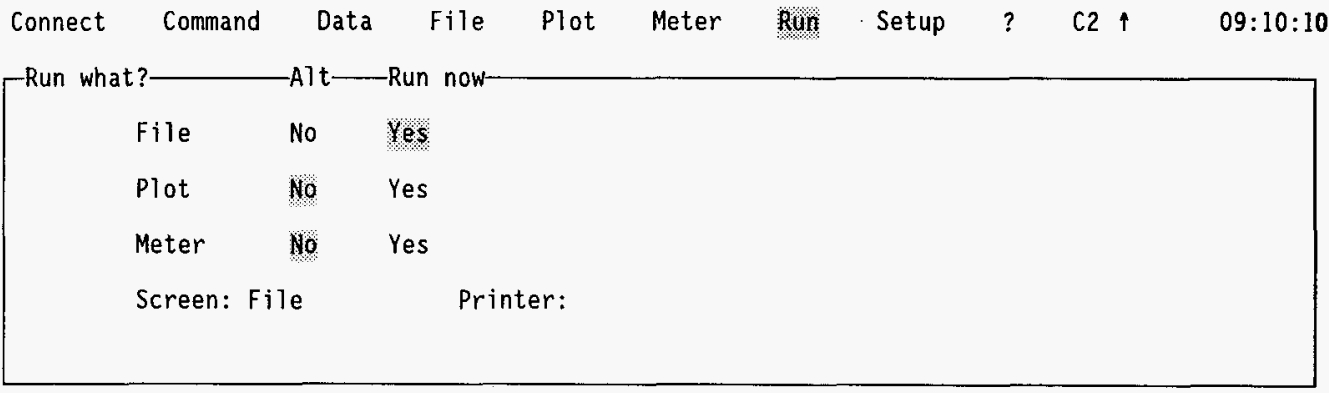




\section{WHC-SD-WM-ATR-149 \\ Revision 0}

Connect Command Data File Plot Meter Run setap ? C2 \& 09:10:10

\begin{aligned} & Setup Type-Alt_- Save- System Task \\ & \hline\end{aligned}

\begin{tabular}{|lll|}
\hline General & \\
Startup Connect & Yes No \\
Autoload Task & Yes No \\
Auto Match & Yes No \\
\hline
\end{tabular}

\begin{tabular}{|lll|} 
Video & \multicolumn{1}{c|}{ Tabitor Type } & Auto Colour Monochrome \\
Startup Colours & Mono Blue/White Red/White LCD Gas Plasma \\
Video Mode & Auto VGA EGA Hercules
\end{tabular}

Printers Setup a text or graphics printer

Connected to COM_2

$0 \quad 12976$ 
WHC-SD-WM-ATR-149

Revision 0

APPENDIX F - FIGURES

F-1 


\section{WHC-SD-WM-ATR-149 \\ Revision 0}

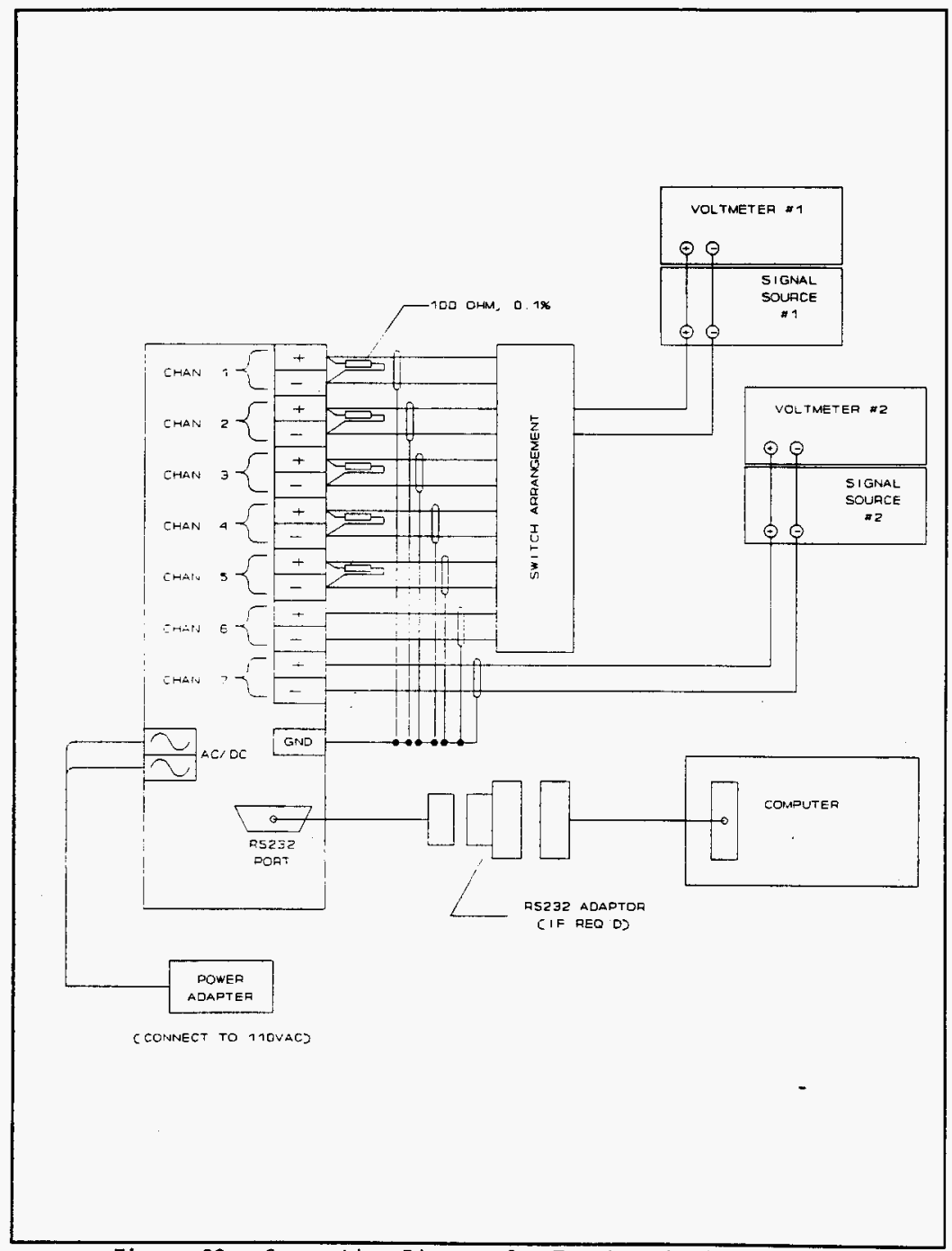

Figure 23. Connection Diagram for Testing the Datalogger. 


\section{WHC-SD-WM-ATR-149 \\ Revision 0}

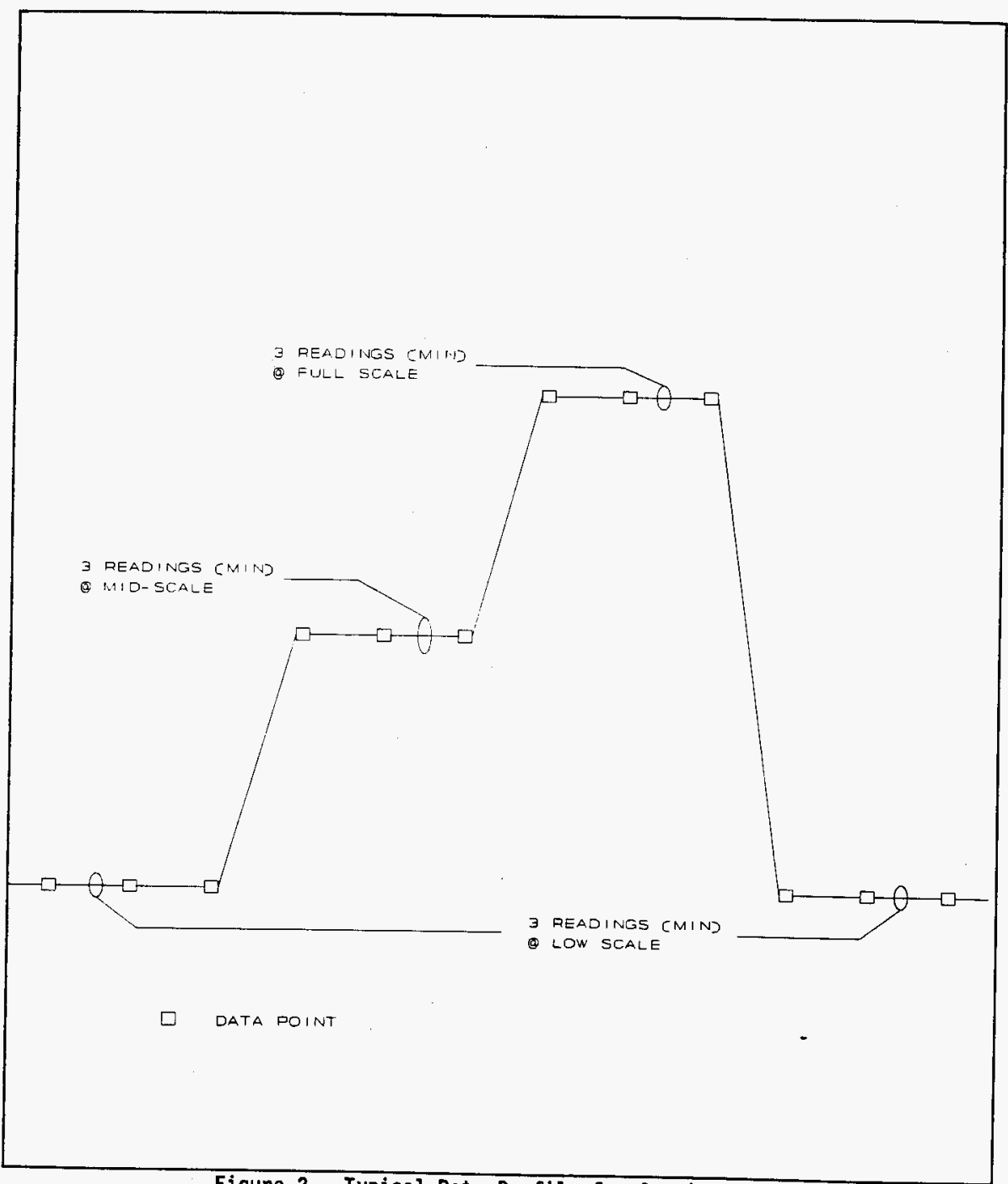

Figure 2. Typical Data Profile for Section 1.7. 
WHC-SD-WM-ATR-149

Revision 0

2 DEARINGS CTYPJ

(9) MID-SCALE

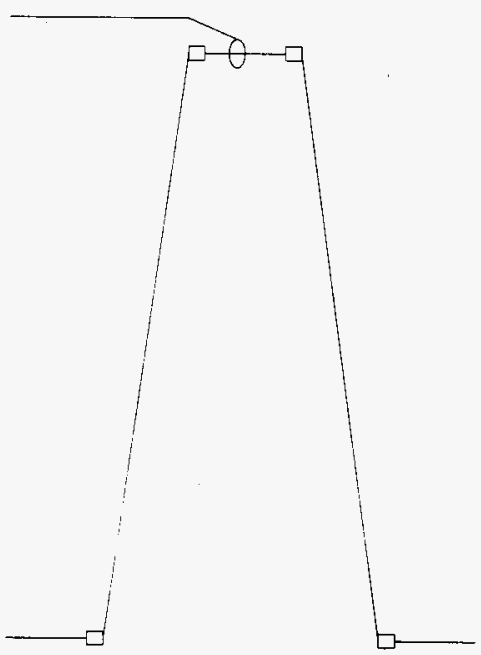

$\square$ DATA FOINT

Figure 3. Typical Data Profile for Section 1.8.

$$
F-4
$$




\begin{tabular}{|c|c|c|c|c|c|}
\hline \multicolumn{6}{|c|}{ DISTRIBUTION SHEET } \\
\hline \multirow{2}{*}{$\begin{array}{l}\text { To } \\
\text { Distribution }\end{array}$} & \multirow{2}{*}{\multicolumn{3}{|c|}{$\begin{array}{l}\text { From } \\
\text { Control Systems Engineering }\end{array}$}} & \multicolumn{2}{|l|}{ Page 1 of 1} \\
\hline & & & & \multicolumn{2}{|l|}{ Date } \\
\hline \multicolumn{4}{|l|}{ Project Title/Work Order } & \multicolumn{2}{|c|}{ EDT No. 141086} \\
\hline \multicolumn{4}{|c|}{$\begin{array}{l}\text { WHC-SD-WM-ATR-149, Rev. 0, Acceptance Test Report for the } \\
\text { 241-AN-107 Caustic Addition Mixer Pump Datalogger }\end{array}$} & \multicolumn{2}{|l|}{ ECN No. N/A } \\
\hline Name & MSIN & $\begin{array}{c}\text { Text } \\
\text { With All } \\
\text { Attach. }\end{array}$ & Text Only & $\begin{array}{l}\text { Attach./ } \\
\text { Appendix } \\
\text { Only }\end{array}$ & $\begin{array}{l}\text { EDT/ECN } \\
\text { Only }\end{array}$ \\
\hline $\begin{array}{l}\text { T. R. Beaver } \\
\text { K. G. Carothers } \\
\text { J. L. Dowell } \\
\text { G. N. Hanson } \\
\text { M. D. Harding } \\
\text { O. B. Haugen } \\
\text { M. N. Islam } \\
\text { W. E. Meeuwsen } \\
\text { R. E. Parizin } \\
\text { J. J. Verderber } \\
\text { S. U. Zaman } \\
\text { Central Files } \\
\text { TFIC }\end{array}$ & $\begin{array}{l}\text { HO-33 } \\
\text { Rl-51 } \\
\text { E6-21 } \\
\text { S5-05 } \\
\text { S5-10 } \\
\text { S5-10 } \\
\text { R3-08 } \\
\text { S5-05 } \\
\text { S4-43 } \\
\text { S1-57 } \\
\text { R3-08 } \\
\text { A3-88 } \\
\text { Rl-20 }\end{array}$ & $\begin{array}{l}x \\
x \\
x \\
x \\
x \\
x \\
x \\
x \\
x \\
x \\
x\end{array}$ & & & $\begin{array}{l}x \\
x\end{array}$ \\
\hline
\end{tabular}

